\title{
unesp
}

GUSTAVO CAPATTI CASSIANO

\section{DETERMINAÇÃO DA INFECÇÃO EM Anopheles POR DIAGNÓSTICO MOLECULAR}

\author{
Dissertação apresentada para a \\ obtenção ao Título de Mestre em \\ Genética.
}

São José do Rio Preto - SP 


\title{
DETERMINAÇÃO DA INFECÇÃO EM Anopheles POR DIAGNÓSTICO MOLECULAR
}

\author{
Dissertação apresentada ao Instituto \\ de Biociências, Letras e Ciências \\ Exatas (IBILCE/UNESP) - São José \\ do Rio Preto para obtenção do título \\ de Mestre em Genética.
}

Orientador: Prof. Dr. Ricardo Luiz Dantas Machado.

Co-orientadora: Profa. Dra. Andrea Regina Baptista Rossit.

São José do Rio Preto - SP 
Cassiano, Gustavo Capatti.

Determinação da infecção em Anopheles por diagnóstico molecular / Gustavo Capatti Cassiano. - São José do Rio Preto : [s.n.], 2010.

109 f. : il. ; $30 \mathrm{~cm}$.

Orientador: Ricardo Luiz Dantas Machado

Dissertação (mestrado) - Universidade Estadual Paulista, Instituto de Biociências, Letras e Ciências Exatas.

1. Malária - Diagnóstico molecular. 2. Diagnóstico molecular. 3. Anopheles. 4. Plasmodium malariae. 5. Plasmodium falciparum. 6. Plasmodium vivax - Variantes. I. Machado, Ricardo Luiz Dantas. II. Universidade Estadual Paulista, Instituto de Biociências, Letras e Ciências Exatas. III. Título.

$$
\text { CDU - } 616.936
$$

Ficha catalográfica elaborada pela Biblioteca do IBILCE Campus de São José do Rio Preto - UNESP 


\section{DETERMINAÇÃO DA INFECÇÃO EM Anopheles POR DIAGNÓSTICO MOLECULAR}

Dissertação apresentada para obtenção do título de Mestre em Genética, junto ao programa de PósGraduação em Genética do Instituto de Biociências, Letras e Ciências Exatas da Universidade Estadual Paulista "Júlio de Mesquita Filho", Campus de São José do Rio Preto.

\section{BANCA EXAMINADORA}

Prof. Dr. Ricardo Luiz Dantas Machado

Professor Doutor

UNESP - São José do Rio Preto

Orientador

Prof. Dr. Mauro Toledo Marrelli

Professor Doutor

Universidade de São Paulo

Prof. Dr. Carlos Eugênio Cavasini

Professor Doutor

Faculdade de Medicina de São José do Rio Preto

São José do Rio Preto, 26 de fevereiro de 2010 
Este trabalho foi desenvolvido no Centro de Investigação de Microrganismos, junto ao Departamento de Doenças Dermatológicas, Infecciosas e Parasitárias da Faculdade de Medicina de São José do Rio Preto (FAMERP), com o auxílio financeiro da Fundação de Amparo à Pesquisa do Estado de São Paulo (FAPESP) com concessão de bolsa de mestrado, $\mathrm{n}^{\circ}$ de processo 2008/02255-8. 
Aos meus pais Orsino $e$

Maria Aparecida e meu irmão Adriano pelo amor $e$ apoio que sempre me deram. 


\section{Agradecimentos}

Ao meu orientador Dr. Ricardo Luiz Dantas Machado, minha imensa gratidão pelos ensinamentos, confiança e amizade que contribuíram para o meu crescimento profissional e acadêmico.

À Dra. Andrea Regina Baptista pela amizade, apoio e colaboração na realização deste trabalho.

Ao Dr. Carlos Cavasini pelo apoio e amizade.

À Dra. Marinete Marins Póvoa, uma amiga de verdade. Ela tornou possível a realização deste trabalho e deu um novo significado ao conceito de trabalho em equipe.

Aos pesquisadores Allan Kardec Ribeiro Galardo e Clícia Denis Galardo, pela oportunidade de desenvolver parte do trabalho no Departamento de Zoologia do IEPA.

À Margarete Gomes e toda sua família, por me acolherem em Macapá e pelo agradável convívio.

Aos organizadores do seminário Laveran/Deane sobre malária, Dr. Cláudio Tadeu Daniel Ribeiro e Dra. Maria de Fátima Ferreira da Cruz, pela oportunidade de participar deste evento.

A todos meus professores, pela competência e generosidade intelectual com que me orientaram.

Aos amigos do CIM, Luciana, Valéria, Lu, Wanessa, Leo, Marcus, Schwazi, Jean, Carla, Cecília, Carol, Amanda e Fabiana pela amizade e disponibilidade em ajudar.

Aos meus amigos, os quais não seriam possíveis aqui nomeá-los, por todo companheirismo, carinho e atenção. 
À minha grande pequena, por fazer minha vida mais feliz.

À Fundação de Amparo à Pesquisa do Estado de São Paulo (FAPESP), pelo auxílio financeiro.

A todos aqueles que contribuíram, direta ou indiretamente, para a realização deste trabalho. 


\section{SUMÁRIO}

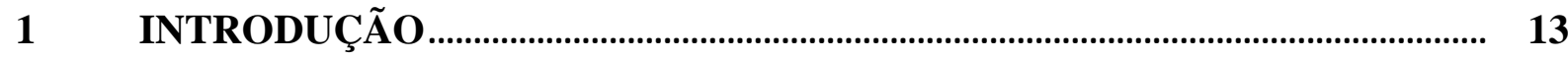

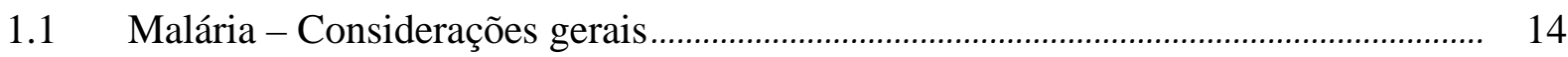

1.2 Epidemiologia do P. vivax, P. falciparum e do P. malariae .......................................... 16

1.3 Situação da malária no Brasil..................................................................................... 17

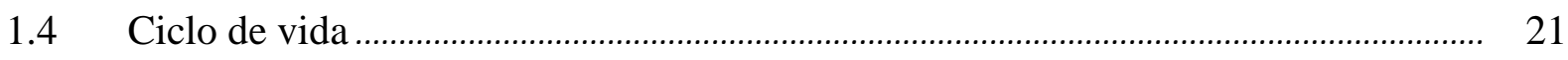

1.5 Desenvolvimento do Plasmodium no vetor ................................................................... 22

1.6 Proteína Circunsporozoítica e os plasmódios humanos .................................................... 25

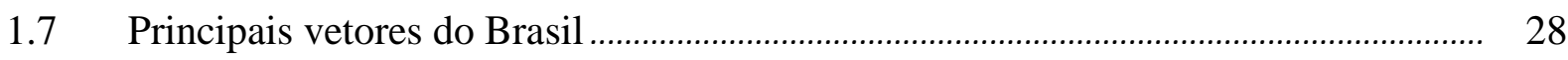

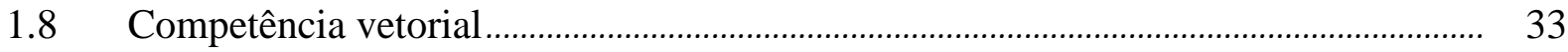

1.9 Métodos para a identificação dos plasmódios em anofelinos ........................................... 36

1.9.1 Métodos moleculares aplicados a detecção de Plasmodium......................................... 38

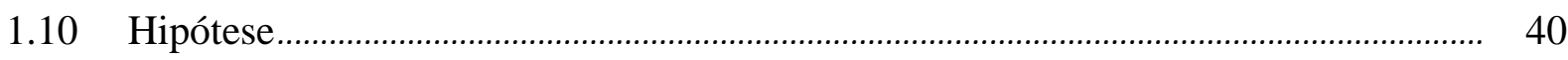

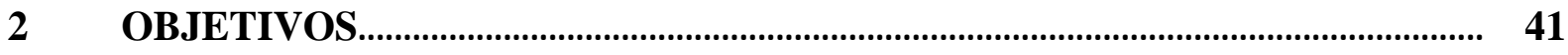

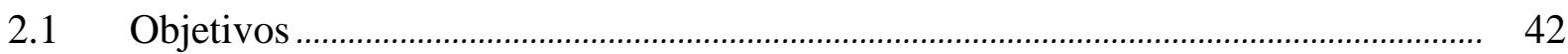

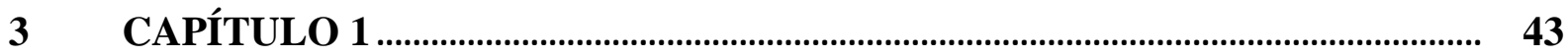

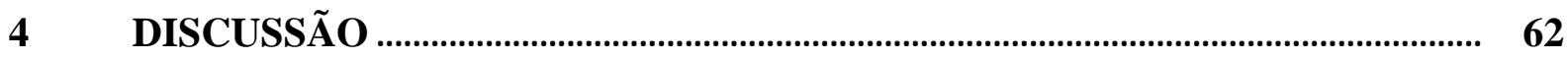

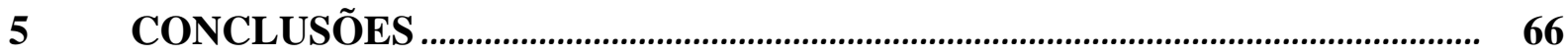

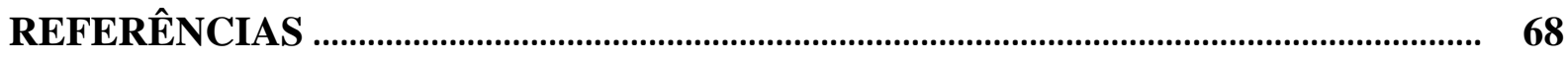

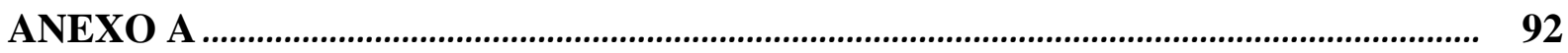

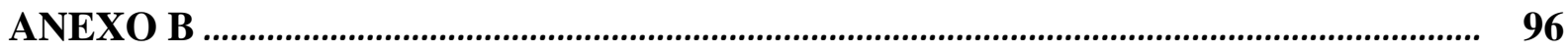

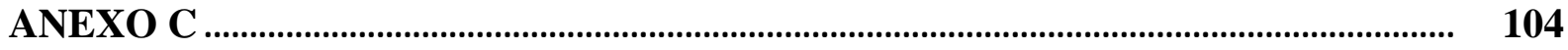

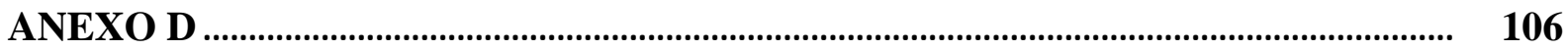

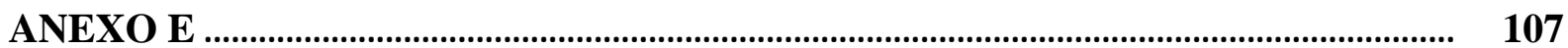




\section{LISTA DE FIGURAS}

Figura 1. Distribuição global da malária segundo risco de transmissão

Figura 2. Número de casos de malária vivax e malária falciparum no Brasil, entre os anos de 1960 e 2007.

Figura 3. Mapa de risco de transmissão de malária por município de notificação segundo estratificação epidemiológica de risco na Amazônia Legal, 2008 .

Figura 4. Ciclo de vida (esquizogonia) do Plasmodium spp

Figura 5. Ciclo de vida do Plasmodium no mosquito vetor

Figura 6. Esquema do gene $C S$ e a sequência de aminoácidos codificada pela região central repetitiva dos parasitos da malária humana.

Figura 7. Distribuição mundial das principais espécies de Anopheles vetores de Plasmodium humano.

Figura 8. Banding patterns of the $C S$-PCR

Figura 9. Sensitivity of the CS-PCR

Figura 10. Specificity of the amplification assay

Figura 11. Banding patterns of CS-PCR-RFLP 
CASSIANO, G. C. Determinação da infecção em Anopheles por diagnóstico molecular. São José do Rio Preto - SP, 2010. 108p. Dissertação (Mestrado em Genética) - Instituto de Biociências, Letras e Ciências Exatas (IBILCE) - Campus de São José do Rio Preto - SP, Universidade Estadual Paulista "Júlio de Mesquita Filho".

\section{Resumo}

Responsável por 300 a 500 milhões de novas infecções e 1,5 a 3 milhões de mortes por ano no mundo inteiro, a malária continua sendo a principal doença parasitária. Se importante é o combate contra os parasitos, importante também é o conhecimento dos aspectos de incidência, distribuição, especificidade de hospedeiros, além do conhecimento de fatores biológicos e moleculares que determinam a distribuição destes. Neste cenário, um dos principais parâmetros analisados para o controle e monitoramento da malária é a detecção de espécies de Plasmodium nos vetores capazes de infectarem humanos. Embora existam diversas metodologias com este fim, a maioria delas apresenta algumas limitações. O objetivo do presente estudo foi desenvolver um método que permita a identificação do $P$. falciparum, do $P$. malariae e das variantes do $P$. vivax no vetor. Uma PCR foi padronizada, utilizando iniciadores contra regiões específicas do gene $C S$. A PCR-RFLP foi utilizada para distinguir as variantes do $P$. vivax. A eficiência da metodologia desenvolvida foi comparada com uma nested-PCR, utilizando Anopheles infectados experimentalmente. Um total de 90 mosquitos foram infectados artificialmente com $P$. vivax $(\mathrm{n}=30), P$. falciparum $(\mathrm{n}=30)$ e P.malariae $(\mathrm{n}=30)$. Estes mosquitos infectados, juntamente com outros 30 não infectados foram avaliados em relação a identificação do Plasmodium por nested PCR e com o CS-PCR. A nested PCR para o P. vivax, $P$. falciparum e P. malariae identificou 19, 16 e 21 mosquitos positivos, respectivamente; enquanto o CS-PCR detectou em 17, 14 e 16 mosquitos, respectivamente. A comparação entre os dois métodos revelou uma boa concordância $(\kappa=0,723,0,867$ e 0,657 , respectivamente, para $P$. vivax, $P$. falciparum e $P$. malariae). Subsequentemente, 
a PCR-RFLP discriminou eficientemente as variantes VK210, VK247 e P. vivaxlike. Este estudo pode ser empregado para um melhor entendimento da dinâmica de transmissão das espécies de malária.

Palavras-chave: Malária; PCR-RFLP; Plasmodium falciparum; Plasmodium malariae; variantes do Plasmodium vivax; Anopheles.

\begin{abstract}
Malaria remains the most serious vector-borne disease, affecting some 300-500 million people annually, causing 1.5-3 million deaths. Is important the fight against the parasites, but it is also important the knowledge of the incidence, host specificity, molecular and biological factors determining the distribution of these parasites. In this scenario, identification of the human-specific Plasmodium species in the mosquito host is an essential component for planning and monitoring of malaria control operations. However, most of the detection methods show some potential limitations. The objective of this study was development an effective assay for detecting Plasmodium falciparum, Plasmodium malariae and Plasmodium vivax variants in Anopheles mosquitoes. A PCR was development targeting the $C S$ gene. A PCR-RFLP was used to distinguish the $P$. vivax variants VK210, VK247 and P. vivax-like. The new PCR assay was compared against a nested PCR using artificially infected Anopheles mosquitoes. A total of 90 mosquitoes were artificially infected with $P$. vivax $(\mathrm{n}=30), P$. falciparum $(\mathrm{n}=$ $30)$ and $P$. malariae $(\mathrm{n}=30)$. These infected mosquitoes along with another 30 unfed mosquitoes were checked for the identification of Plasmodium by nested PCR and with the CS-PCR. Nested PCR for P. vivax, $P$. falciparum and $P$. malariae detected positive infection in 19, 16 and 21 mosquitoes respectively; whereas CS-PCR detected in 17, 14 and 16 mosquitoes, respectively. The comparison revealed a close agreement between the two assays $(\kappa=0.723,0.867$ and 0.657 , respectively for $P$. vivax, $P$. falciparum and $P$. malariae groups). Subsequently, PCR-RFLP efficiently discriminate $P$. vivax variants VK210,
\end{abstract}


VK247 and $P$. vivax-like. This study describes a new assay that effectively detects $P$. vivax, $P$. falciparum and $P$. vivax variants. This assay may be employed to improve the understanding of malaria transmission dynamics by Anopheles species.

Keywords: Malaria, PCR-RFLP, Plasmodium falciparum, Plasmodium malariae, P. vivax variants, Anopheles 
Introdução 


\section{INTRODUÇÃO}

\subsection{Malária - Considerações gerais}

A malária é uma doença parasitária causada por protozoários do gênero Plasmodium transmitidos naturalmente pela picada de fêmeas de mosquitos do gênero Anopheles Meigen, 1818 a diferentes espécies de mamíferos. (LEVINE, 1988). Estes parasitos pertencem ao Reino Protista, Filo Apicomplexa, Classe Sporozoea, Ordem Hemosporidiida, Família Plasmodiidae e Gênero Plasmodium Marchiafava e Celli, 1885. Dentre as diferentes espécies, quatro são reconhecidamente agentes etiológicos s da malária humana: Plasmodium vivax Grassi e Feletti, 1890, Plasmodium falciparum Welch, 1897, Plasmodium malariae Laveran, 1881 e Plasmodium ovale Stephens, 1922. Atualmente, uma quinta espécie, o Plasmodium knowlesi Sinton e Mulligan, 1932 tem sido considerada por alguns autores como causadora de malária em humanos (McCUTCHAN, 2008).

Os dados disponíveis sobre a ocorrência de malária, em todo o mundo, são bastante imprecisos. No entanto, todas as estimativas são muito elevadas (SNOW et al., 2005; CARTER e MENDIS, 2006). Segundo a Organização Mundial de Saúde, ocorreram 247 milhões de casos de malária em 2006, resultando em aproximadamente um milhão de mortes, principalmente de crianças menores de cinco anos residentes na África (WHO, 2008). Embora a grande maioria dos casos ocorra no continente africano, a doença encontra-se amplamente distribuída na América Latina, Sudeste Asiático e Oceania (Figura 1), sendo que 109 países no mundo possuem áreas de risco de transmissão de malária (WHO, 2008). Utilizando sistemas de informação geográfica combinados com mapas históricos, Hay et al. (2004) mostraram que $48 \%$ da população mundial reside em áreas de risco, dados superiores ao que tem sido descrito na literatura. Este fato pode estar 
relacionado, principalmente, ao crescimento populacional (WHO, 1999; WHO, 2000).

Nas Américas, a transmissão ocorre em 22 países, estimando-se que 137 milhões de pessoas vivem em áreas com distinta intensidade de transmissão, já que diferem em características sociais, econômicas e ecológicas. No ano de 2006 foram registrados aproximadamente um milhão de casos de malária nas Américas, e o país com maior contingente de casos notificados foi o Brasil (52,7\%), seguido pela Bolívia (20,0\%) e Colômbia (11,5\%) (WHO, 2008).

A malária é também uma doença re-emergente em áreas onde estava sob controle ou erradicada, como em repúblicas da Ásia Central e na Coréia (WHO, 2008). Além disso, nos últimos anos, foi verificado um aumento da forma importada em países onde a doença não é endêmica em consequência do turismo, das cooperações entre países e, por fim, das migrações provocadas por guerras. Ainda, em face do fenômeno do aquecimento global a malária, assim como outras doenças transmitidas por mosquitos, apresenta alto risco de expansão para inúmeras regiões, (PATZ e OLSON, 2006; I.P.C.C., 2007).

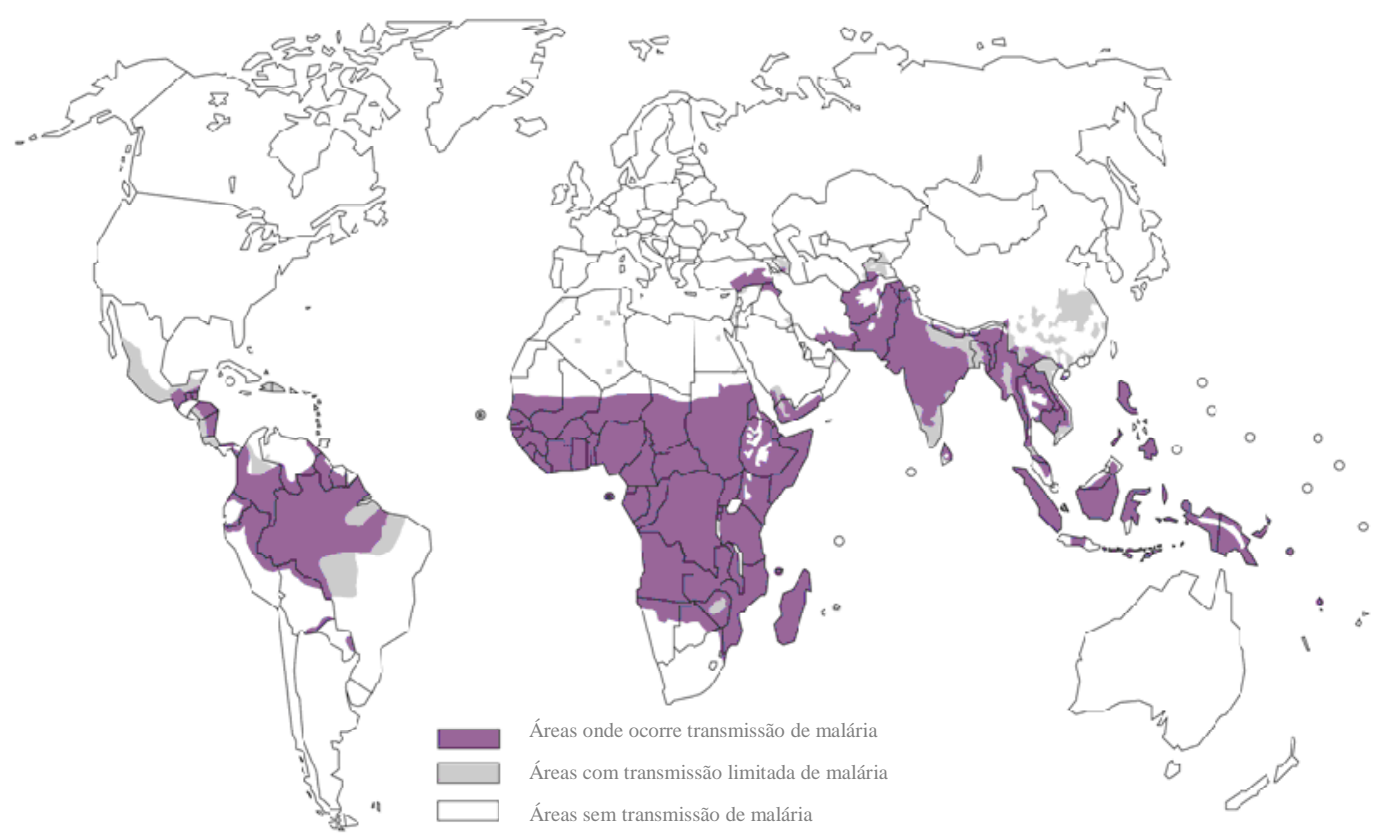

Figura 1 - Distribuição global da malária segundo risco de transmissão. Fonte: WHO (2008). 


\subsection{Epidemiologia do $P$. vivax, $P$. falciparum e do $P$. malariae}

O P. vivax é uma espécie amplamente distribuída no mundo, ocorrendo principalmente em regiões tropicais e subtropicais. A maior proporção do número de casos acontece no Sul e no Sudeste da Ásia (provavelmente mais de $80 \%$ das infecções) muito embora exista forte suspeita de que as infecções do continente africano não sejam corretamente notificadas (GUERRA et al., 2006; ROSENBERG, 2007). Nas Américas, apesar do número de malária vivax comparativamente inferior, esse plasmódio responde por mais de $70 \%$ de todos os casos (WHO, 2008) trazendo prejuízos significativos ao desenvolvimento socioeconômico da região.

A distribuição geográfica do $P$. falciparum se sobrepõe a do $P$. vivax, exceto em regiões temperadas, tais como na península coreana, devido ao fato do P. vivax completar seu ciclo de desenvolvimento em regiões mais frias. Outra exceção ocorre em regiões da África Subsaariana, mas por outra razão - nelas, uma grande parcela da população não apresenta o antígeno Duffy, um receptor eritrocítico que permite a invasão do P. vivax (MILLER et al., 1976). Nestas regiões, o $P$. falciparum ocasiona mais de $90 \%$ dos casos, o que contribui para a grande mortalidade registrada neste continente. Isso por que quase todas as complicações e mortes relacionadas à malária são associadas à essa espécie (WHO, 2008).

O P. malariae teve prevalência maior no passado. Hoje, sua distribuição está quase que limitada à África e, mais raramente, no Pacífico Oeste e nas Américas do Sul e Central (CARTER e MENDIS, 2002). Nas áreas endêmicas da África, geralmente as infecções por $P$. malariae são mistas com o $P$. falciparum. Nas Américas, acredita-se que a malária ocasionada por este agente pode ter caráter zoonótico, uma vez que $P$. malariae compartilha identidade genética com o parasito de primatas P.brasilianum Gonder e Berenberg-Gossler, 1908 (AYALA et al., 1999) observado na América do Sul principalmente em símios das famílias Cebidae e Atelidae (DEANE et al., 1969; DEANE, 1992; FANDEUR 
et al., 2000). Interessantemente, tanto símios quanto humanos apresentaram altos níveis de soropositividade a antígenos do P. malariae/P. brasilianum (VOLNEY et al., 2002; DUARTE et al., 2006).

\subsection{Situação da malária no Brasil}

Até o final do século XIX, a malária estava presente em todo o território nacional, com exceção de algumas áreas da região Sul (BARCELAR, 1963). Após o Brasil adotar a estratégia de erradicação da malária, preconizada pela Organização Mundial de Saúde, a doença foi eliminada em diversos Estados e encontrou seus menores índices no início da década de 1970, quando cerca de 52.000 casos foram registrados (LOIOLA et al., 2002). A partir de então, a incidência da malária voltou a ter um aumento progressivo, atingindo, em 1999, aproximadamente 610.000 casos (BRASIL, 2009) (Figura 2).

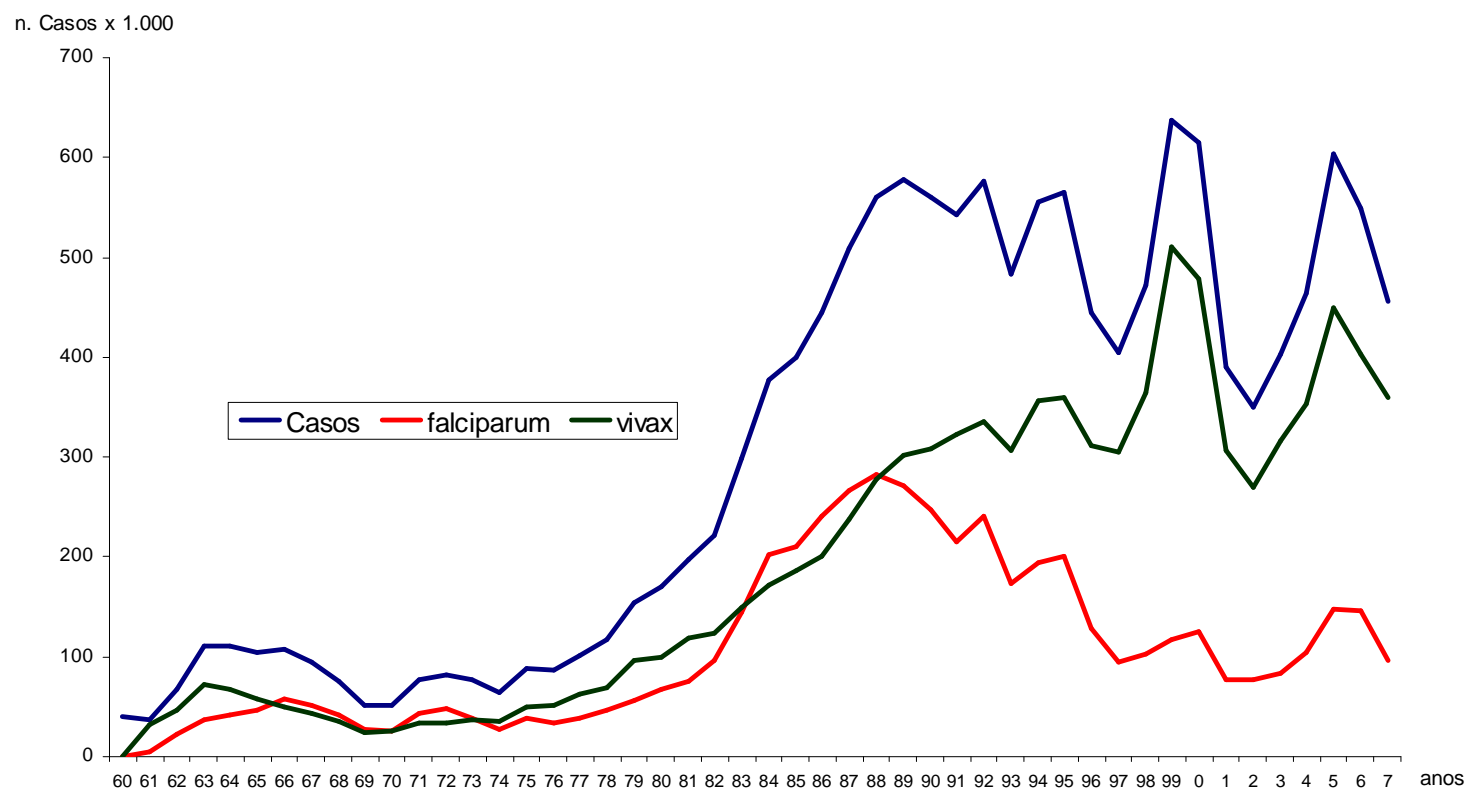

Figura 2 - Número de casos de malária vivax e malária falciparum no Brasil, entre os anos de 1960 e 2007.

Fonte: BRASIL (2008). 
Na década de 80 a incidência da malária, em ascensão, teve como causa principal o processo de desenvolvimento e de ocupação da Amazônia. Isso por que neste período iniciou-se um intenso fluxo migratório, na grande maioria de pessoas das regiões Nordeste, Centro-Oeste e Sul do país, sem imunidade adquirida. Geralmente, neste grupo populacional, a primo-infecção por $P$. falciparum apresentava maior letalidade (SABROZA, 1985), conforme corroborado pela tendência ascendente de mortalidade e letalidade neste mesmo período. Tendência esta, acrescida também, pela incipiente estrutura de serviços de saúde nas áreas de colonização recente, a dificuldade de acesso aos serviços de saúde existente e o difícil acesso dos profissionais de saúde à localidade (TAUIL e DANIEL-RIBEIRO, 1998).

Nos últimos anos houve um declínio da incidência da doença e, no ano de 2008, foram registrados 308.472 casos de malária, sendo que quase a totalidade destes originários da Amazônia (BRASIL, 2008). De fato, a maioria é registrada na região Norte nos Estados do Pará, Amazonas, Rondônia, Acre, Amapá, Tocantins, parte da região Centro-Oeste, no Estado do Mato Grosso e por fim, a Oeste da região Nordeste, no Estado do Maranhão. No entanto, não se apresenta distribuída uniformemente uma vez que são detectados níveis diferenciais de transmissão da doença entre certas áreas (BRASIL, 2008) (Figura 3). Estas particularidades epidemiológicas decorrem, principalmente, das diversas formas de ocupação do solo e modalidades de exploração econômica dos recursos naturais, bem como da distribuição vetorial e das características genéticas da população (TAUIL e DANIEL-RIBEIRO, 1998).

Tal declínio sofreu influência das atividades de controle, sem dúvida, mas outros fatores estiveram seguramente envolvidos, como a mobilidade populacional. Com o esgotamento de várias atividades econômicas nas áreas rurais da região Amazônica, principalmente o garimpo artesanal, a região tornouse palco de movimentos migratórios do campo para as cidades (CERUTTIJUNIOR, 2007). Com condições menos favoráveis de transmissão, o número de casos urbanos tende a ser menor do que aquele observado na área rural. Por outro 
lado, tais movimentos migratórios ensejam a eclosão de surtos de malária urbana (BRASIL, 2009).

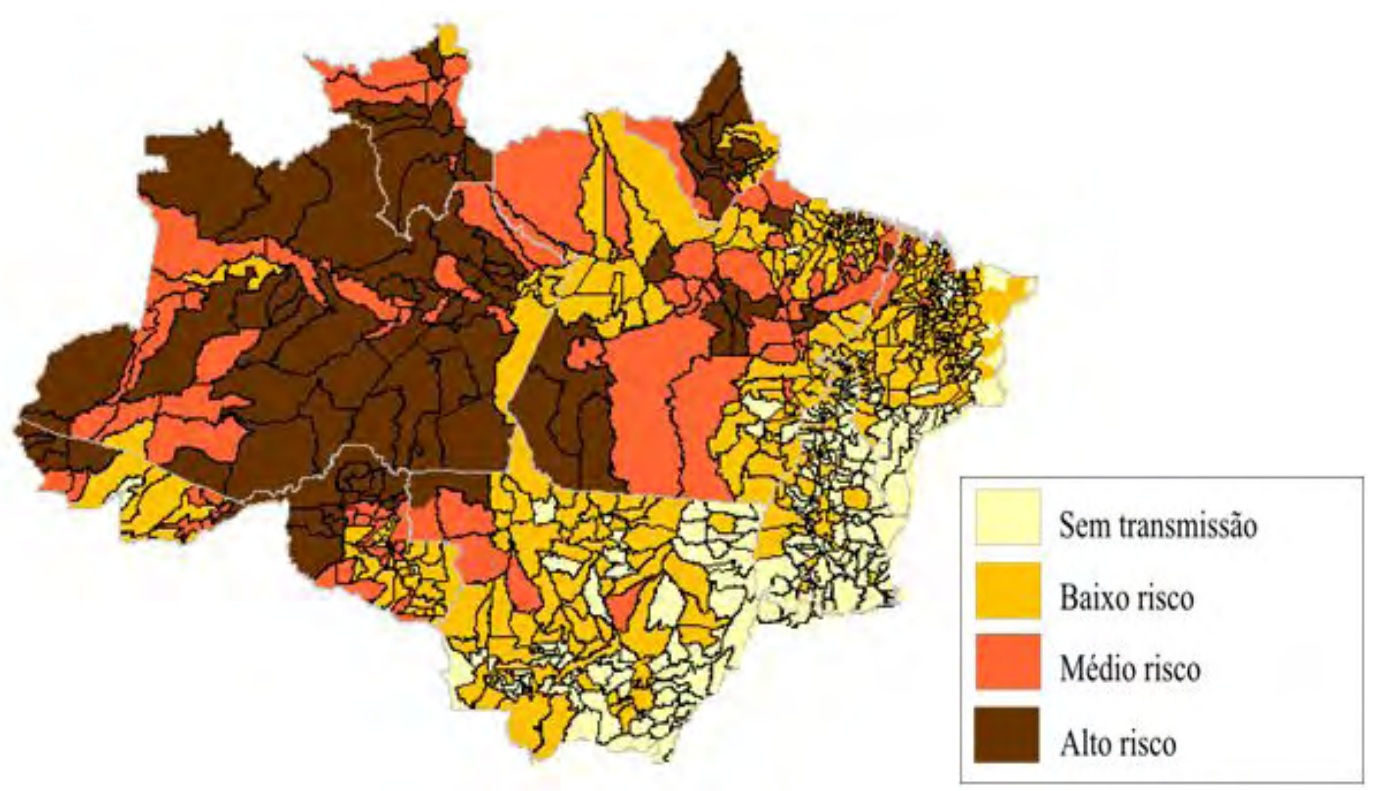

Figura 3 - Mapa de risco de transmissão de malária por município de notificação segundo estratificação epidemiológica de risco na Amazônia Legal, 2008.

Fonte: BRASIL (2008).

$\mathrm{Na}$ região Extra-Amazônica, têm sido registrados surtos de malária decorrentes da introdução da doença por migrantes infectados oriundos das áreas de transmissão (BRASIL, 2008). Esse quadro é preocupante uma vez que toda a região Extra-Amazônica é receptiva para transmissão de malária e os serviços de vigilância em saúde de alguns municípios são carentes de estrutura adequada para enfrentar o problema. Outro desafio que se impõe aos programas de controle é a eliminação de casos autóctones esporádicos que ocorrem em áreas focais restritas. Tais casos estão localizados nas margens do lago da reserva hidrelétrica de Itaipu, em áreas cobertas pela Mata Atlântica nos Estados do Espírito Santo, Rio de Janeiro, São Paulo e Bahia (BRASIL, 2008). Ainda, mesmo em regiões localizadas mais ao Sul do país, no Estado de Santa Catarina, observam-se casos autóctones de malária (MACHADO et al., 2003a). Em regiões de Mata Atlântica a malária está associada a existência de plantas da família Bromeliaceae, que 
funcionam como criadouros de anofelinos do subgênero Kerteszia Theobald, 1905. A malária associada a estes vetores, causada por $P$. vivax ou P. malariae, apresenta quadro bem específico com parasitemias baixas, sintomas moderados e transmissão isolada (CURADO et al., 1997).

Em relação às espécies de Plasmodium, com o surgimento de resistência do $P$. falciparum à cloroquina, o número de infecções de malária provocadas por esta espécie ultrapassou o número de casos de $P$. vivax, durante o período de 1984 a 1988. A partir deste, outro perfil epidemiológico foi observado, no qual o $P$. vivax novamente figura como a espécie predominante no Brasil (COURA et al., 2006). Embora os motivos destas inversões ainda não estejam totalmente compreendidos, a utilização da mefloquina ao tratamento de $P$. falciparum pode ter contribuído para a queda do número de casos. Ademais, a doença provocada pelo $P$. vivax muitas vezes se manifesta de forma benigna, levando o paciente a não aderir ao tratamento de maneira correta, ocasionando recaídas, que aumentam as fontes de infecção e a quantidade de malária provocada por esta espécie. Soma-se a esse quadro a circulação de cepas de $P$. vivax resistentes a antimaláricos tais como cloroquina e mefloquina (ALECRIM et al., 1999). Atualmente, com a implantação de um novo esquema terapêutico, um combinado de lumefantrine com um derivado de artemisinina (Coartem $\left.{ }^{\circledR}\right)$, observa-se uma redução no número de casos de P. falciparum (BRASIL, 2009).

Infecções por $P$. malariae são raramente registradas, dificilmente excedendo 300 casos por ano (TAUIL e DANIEL-RIBEIRO, 1998), embora este número possa ser sub-notificado na Amazônia brasileira. No Estado de Rondônia, por exemplo, $10 \%$ de positividade para $P$. malariae foram detectados no sangue de 96 pacientes, com a utilização da reação em cadeia da polimerase (PCR) (CAVASINI et al., 2000). Entre um grupo de garimpeiros do Mato Grosso, Fontes (2001) detectou 1,1\% de P. malariae por exame hemoscópico, enquanto Scopel et al. (2004), realizando PCR nestas mesmas amostras, ampliou tal prevalência para 11,8\%. Lorenzetti et al (2008), também via PCR, encontraram em amostras de pacientes diagnosticados como infectados por $P$. falciparum, infecções mistas com o P. malariae. 


\subsection{Ciclo de vida}

O ciclo de vida do Plasmodium spp. (Figura 4) é constituído por uma fase sexuada exógena (esporogônica), durante a qual ocorre a multiplicação dos parasitos nos mosquitos do gênero Anopheles (hospedeiro definitivo) e uma fase assexuada endógena (esquizogônica), onde ocorre a multiplicação no homem (hospedeiro intermediário) em células parenquimatosas do fígado (esquizogonia hepática) ou nos eritrócitos (esquizogonia eritrocitária) (SINNIS e COPPI, 2007).

A infecção inicia-se durante o repasto sanguíneo do mosquito fêmea infectado quando este inocula, juntamente com a saliva, os esporozoítos que penetram na corrente sanguínea. Estes, por sua vez, invadem os hepatócitos onde crescem e se multiplicam, diferenciando-se em esquizontes hepáticos. A esta fase chama-se esquizogonia hepática; cuja duração depende da espécie de Plasmodium. No ciclo de vida do P. vivax e do P. ovale os esporozoítos podem originar hipnozoítos, que permanecem no hepatócito em um estado dormente, durante o qual não se dividem, até meses ou anos mais tarde. No ciclo do $P$. falciparum e do $P$. malariae, inicia-se de imediato a maturação dos esquizontes hepáticos da qual resultam os merozoítos hepáticos que são liberados para a corrente sanguínea por lise dos hepatócitos.

Após esta invasão, inicia-se a esquizogonia eritrocitária, na qual os merozoítos se diferenciam em trofozoítos e estes por divisões sucessivas dão origem aos esquizontes eritrocitários. Após lise do eritrócito parasitado, são liberados novos merozoítos na corrente sanguínea, com invasão cíclica de novos eritrócitos e sintomatologia febril associada à lise celular. Alguns merozoítos, após invasão dos eritrócitos, não evoluem para esquizontes, mas diferenciam-se nas formas sexuadas do parasito, os gametócitos feminino e masculino. Estes, em fase de maturação, se e quando ingeridos pela fêmea do mosquito durante o repasto sangüíneo, desenvolvem-se em seu estômago dando origem a macrogâmetas e microgâmetas que, após fertilização, dão inicio ao ciclo 
esporogônico. Completado este ciclo, novos esporozoítos irão se alojar dentro das glândulas salivares (SINNIS e COPPI, 2007).

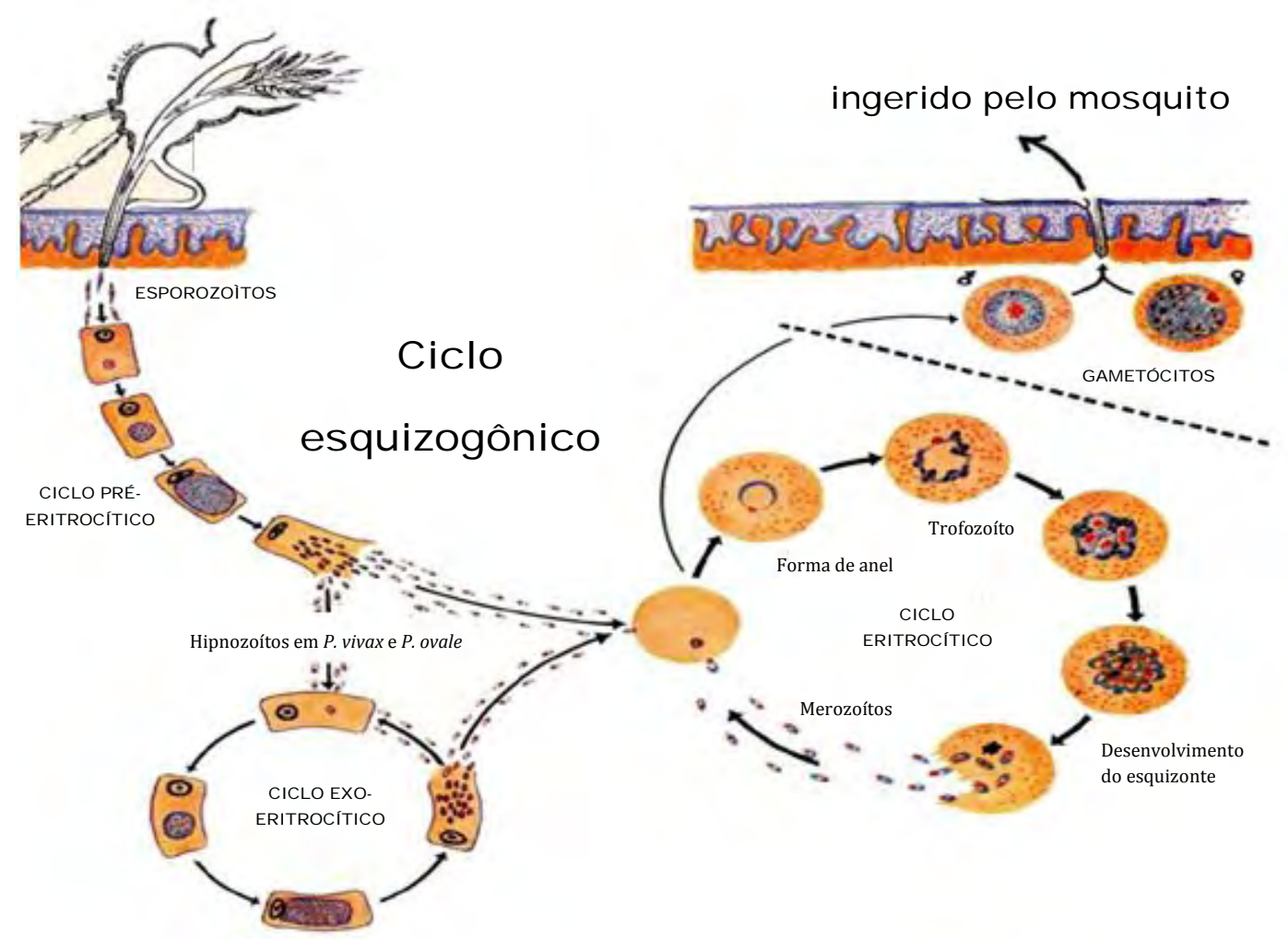

Figura 4 - Ciclo de vida (esquizogonia) do Plasmodium spp.

Fonte: Adaptada de < http//vcrc.res.in/malpar.html >. Acesso em 14 jun. 2009.

\subsection{Desenvolvimento do Plasmodium no vetor}

O desastroso sucesso da malária pode ser em grande parte atribuído ao vetor envolvido na transmissão, ou seja, aos mosquitos pertencentes a família Culicidae. Entretanto, para que o Plasmodium consiga prosseguir seu desenvolvimento dentro do inseto, são necessárias inúmeras adaptações.

No trato digestivo do mosquito, as formas sexuais do parasito (micro e macrogametócitos) sofrem mudanças morfológicas que culminam na fertilização (Figura 5). Dentre estas mudanças, o processo de exflagelação do 
microgametócito é induzido por alguns fatores presentes nesse órgão: a baixa de temperatura (de $37^{\circ} \mathrm{C}$ para $25^{\circ} \mathrm{C}$ ), um aumento no $\mathrm{pH}$ (SINDEN, 1983; KAWAMOTO et al., 1991) e por fatores que estimulam este processo, presentes nos mosquitos, tais como o ácido xanturênico (BHATTACHARYA e KUMMAR, 2001). A macrogametogênese envolve a saída dos macrogametócitos do interior dos eritrócitos presentes no sangue ingerido. Neste momento, os gametas estão sujeitos a ação dos anticorpos do hospedeiro vertebrado que podem ter sido juntamente ingeridos após o repasto sangüíneo, bem como proteínas do sistema complemento (LENSEN et al., 1997; GULIA et al., 2002), os quais podem bloquear ou reduzir a infectividade dos gametócitos (LENSEN et al., 1997; BHARTI et al., 2006).

A fertilização e a formação do zigoto ocorrem rapidamente (em até uma hora) (SINDEN, 1983), com meiose subsequente imediata. Dentro de 24 horas o zigoto completará seu desenvolvimento, originando o oocineto, que necessita ultrapassar a matriz peritrófica (uma camada quitinosa que reveste o sangue ingerido, no estômago do inseto) e o epitélio do intestino para se alojar na membrana basal do órgão, quando é então denominado oocisto (SIDEN-KIAMOS e LOUIS, 2004). O desenvolvimento junto à membrana basal protege o oocisto do sistema imune do mosquito, uma vez que este reconhece a membrana basal como "próprio". O reconhecimento do "não-próprio" ativa a cascata proteolítica de serino proteases que acionam a resposta efetora, ativando as vias de sinalização que promovem a melanização, o que acarretaria em uma subsequiente destruição do oocisto (MICHEL e KAFATOS, 2005). Este processo de divisão esporogônica representa a fase mais longa e o único estágio de desenvolvimento extracelular do Plasmodium em seu ciclo de vida, e resulta em milhares de esporozoítos (BATON e RANFORD-CARTWRIGHT, 2005).

Após saírem do oocisto, os esporozoítos são liberados na hemolinfa do inseto, e irão alcançar as glândulas salivares, localizadas no tórax (Figura 5). De maneira geral, o processo de invasão dos esporozoítos é ineficiente, geralmente menos de $20 \%$ do total produzido conseguirá invadir as glândulas salivares (KOROCHKINA et al., 2006; HILLYER et al., 2007), em um processo que 
totaliza aproximadamente 8 horas. Então, os esporozoítos se tornam susceptíveis ao sistema imune do inseto (HILLYER et al., 2007). Uma vez bem sucedido o processo de invasão, os esporozoítos continuam infectivos por toda a vida do mosquito (BEIER, 1998).

O tempo necessário para completar o desenvolvimento esporogônico é variável de acordo com a espécie de Plasmodium e da temperatura. Em 1949, Boyd (revisto em BEIER, 1998) realizou um clássico experimento, avaliando o impacto da mesma. Nela, o ciclo do P. falciparum levou 9 dias a $30^{\circ} \mathrm{C}, 10$ dias a $25^{\circ} \mathrm{C}, 11$ dias a $24^{\circ} \mathrm{C}$ e 23 dias a $20^{\circ} \mathrm{C}$. A $25^{\circ} \mathrm{C}$, o $P$. vivax completa seu ciclo, enquanto o $P$. malariae requer de 15 a 20 dias para tanto. De maneira geral, o tempo do desenvolvimento esporogônico não parece variar de acordo com a espécie do hospedeiro.

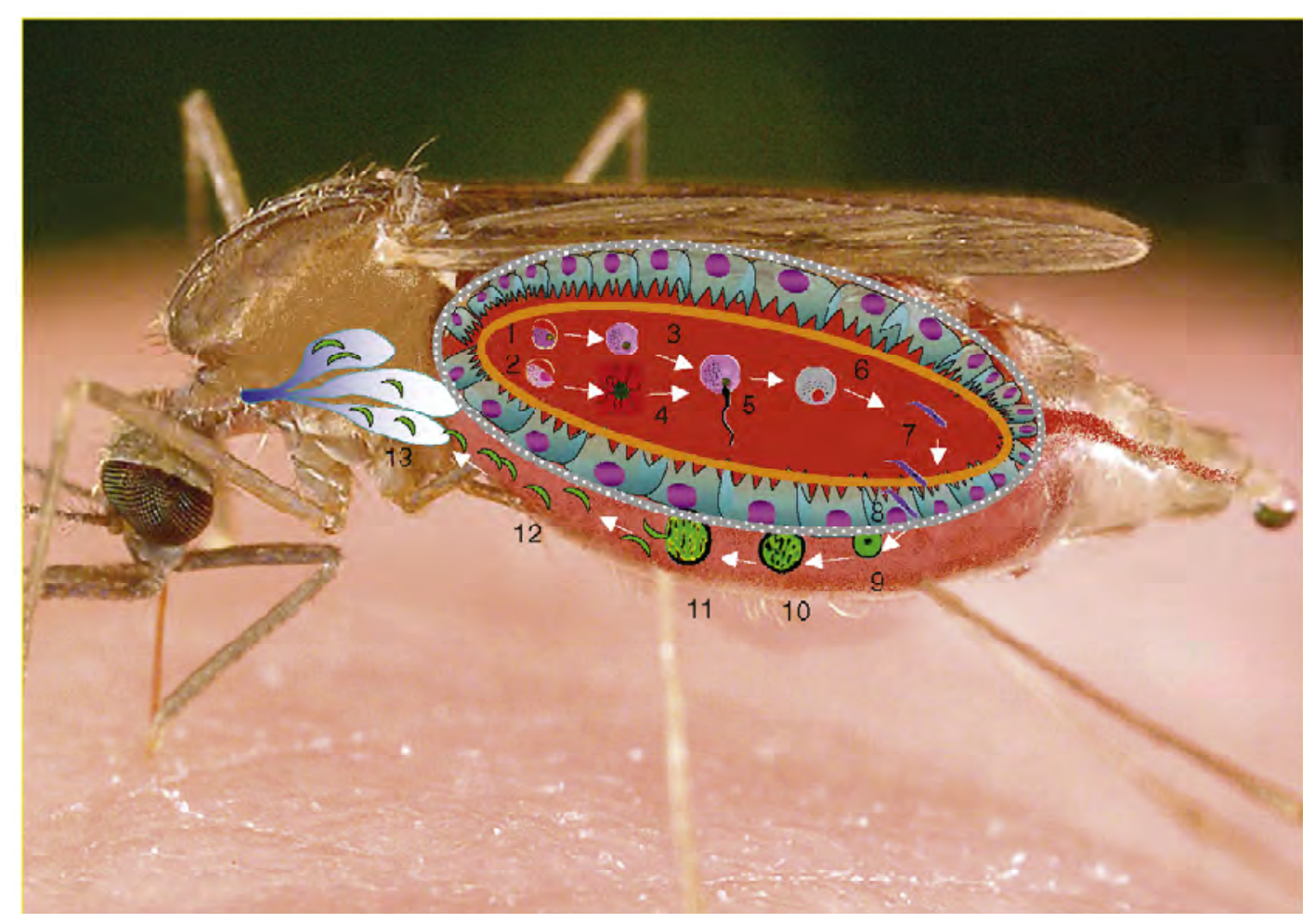

Figura 5 - Ciclo de vida do Plasmodium no mosquito vetor. Os gametócitos (1 e 2) diferenciamse em gametas (3 e 4). O gameta masculino fertiliza o gameta feminino (5), gerando o zigoto (6), que se diferencia em oocineto (7). O oocineto maduro atravessa a matriz peritrófica e o epitélio do intestino (8), para então formar o oocisto (9). Após o desenvolvimento do oocisto (10 e 11), esporozoítos são liberados na hemolinfa (12) e invadem as glândulas salivares (13).

Fonte: GHOSH e JACOBS-LORENA (2009). 


\subsection{Proteína Circunsporozoítica e os plasmódios humanos}

O esporozoíto é a forma infectante do Plasmodium, inoculado a partir da glândula salivar do vetor em seu repasto hematofágico. Por ser a primeira forma a entrar em contato com o sistema imune do hospedeiro, atraiu a atenção dos pesquisadores envolvidos na tentativa de desenvolver vacinas antimaláricas. A estrutura da proteína majoritária que recobre a superfície do esporozoíto do Plasmodium recebeu o nome de proteína circunsporozoítica ou, de forma abreviada, CSP. Ela é primordial para o desenvolvimento dos esporozoítos nos mosquitos, ao desempenhar papel essencial no processo de invasão das glândulas salivares (MÉNARD et al., 1997) e também é responsável pelo reconhecimento e invasão dos hepatócitos no hospedeiro vertebrado (RATHORE et al., 2002).

O gene $C S$ está presente em uma cópia por genoma haplóide, não possui introns e codificaa proteína CSP que varia em comprimento entre as diferentes espécies de Plasmodium, mas que, de forma geral, apresenta aproximadamente 400 aminoácidos (HUGHES, 1991). O gene CS está dividido em três regiões: uma região central formada por nucleotídeos repetidos de forma seqüenciada, flanqueada por duas regiões não repetitivas nas extremidades 5' e 3' do gene. Dois segmentos gênero-conservados, região I e região II, estão por sua vez localizados nas regiões 5' e 3', respectivamente (QARI et al., 1994) (Figura 6).

A sequência de $C S$ foi primeiramente caracterizada para o P. knowlesi (OZAKI et al., 1983). A estrutura da proteína, deduzida a partir da sequência de nucleotídeos da cepa $\mathrm{H}$, possui aproximadamente $40 \%$ de seu total constituída pela região repetitiva, que apresenta 12 repetições de doze aminoácidos (NAGQPQAQGDGA) (OZAKI et al., 1983).

Posteriormente, analisando a CSP do P. falciparum, Dame et al. (1984) verificaram que esta proteína contém aproximadamente um peso molecular de 58 KDa. A região repetitiva da proteína possui cerca de 40 repetições dos tetrapeptídeos NANP, em maior extensão, e NVDP, em menor número de repetições. Esta região contém epítopos de célula B (ZAVALA et al., 1983) e é 
flanqueada por uma região amino-terminal pouco variante e por uma região carboxi-terminal altamente variável, onde epítopos de células-T têm sido identificados (LOCKYER et al., 1989; GONZALES et al., 2000).

O gene $C S$ do $P$. malariae apresenta diversidade em nível nucleotídico, principalmente na região repetitiva e, em menor grau, na região 3'. A região 5' do gene se mostrou inteiramente conservada em todas sequências descritas (TAHAR et al., 1998). A porção central da CSP desta espécie apresenta duas sequências de aminoácidos, uma principal (NAAG), apresentando de 42 a 46 repetições e outra (NDA/EG), variando de 6 a 7 repetições (TAHAR et al., 1998).

O P. vivax possui a proteína CSP constituída por 373 aminoácidos, contendo uma região central de 19 sequências repetidas do nonapeptídeo AspArg-Ala-Asp/Ala-Gly-Gln-Pro-Ala-Gly (DRAD/AGQPAG). Um aspecto interessante desta proteína é a homologia de suas regiões não repetitivas com as da CSP de P. cynomolgi Mayer, 1907 e P. knowlesi (ARNOT et al., 1985). Entretanto, a homologia de sequência com a CSP de outro parasito humano, o $P$. falciparum, é baixa (ARNOT et al., 1985).

Posteriormente, novos estudos revelaram que a sequência desta proteína não estava conservada em todos isolados de $P$. vivax. Na Tailândia, esporozoítos obtidos da glândula salivar de mosquitos cujo repasto havia sido realizado no sangue periférico de indivíduos infectados com $P$. vivax não eram reconhecidos por anticorpos específicos pela técnica de Ensaio de imunoabsorção-enzimática (ELISA). Tal reatividade nula ocorreu em 14\% dos casos humanos avaliados (ROSENBERG et al., 1989). Esta proteína variante tem 17 sequências repetidas de um nonapeptídeo diferente: Ala-Asn-Gly-Ala-Gly/Asp-Asn/Asp-Gln-Pro-Gly (ANGA(G/D)(N/D)QPG) (ROSENBERG et al., 1989) e foi denominada de VK247. Mais tarde, novos estudos revelaram que o número de repetições na porção repetitiva da CSP, tanto de $P$. vivax clássico (VK210) quanto de VK247 não é constante, variando entre 15 e 21 repetições (MANN et al., 1995; LIM et al., 2001; KIM et al., 2002).

No ano de 1993, Qari et al. (1993a) avaliando a identidade de oito isolados de $P$. vivax de Papua Nova Guiné relataram a existência de uma nova variante, 
denominada $P$. vivax-like. O seqüenciamento da $C S$ desses parasitos possibilitou inferir que a proteína correspondente contém 16 cópias da sequência repetida APGANQ(E/G)GGAA (QARI et al., 1993b). Curiosamente, essa sequência é praticamente idêntica a CSP do P. simiovale Dissanaike, Nelson, e Garnham, 1965, um parasito originalmente identificado em macacos do Sri Lanka (Macaca sinica) que, por sua vez, é semelhante morfologicamente a outro parasito de malária humana, o P. ovale Stephens, 1922 (QARI et al., 1993a; ESCALANTE et al., 1995). A homologia com P.vivax clássico e com a VK247, entretanto, era de apenas 83\% (QARI et al., 1993a), o que levou alguns autores à suposição ainda não confirmada de que esta variante possa representar uma espécie diferente de Plasmodium.

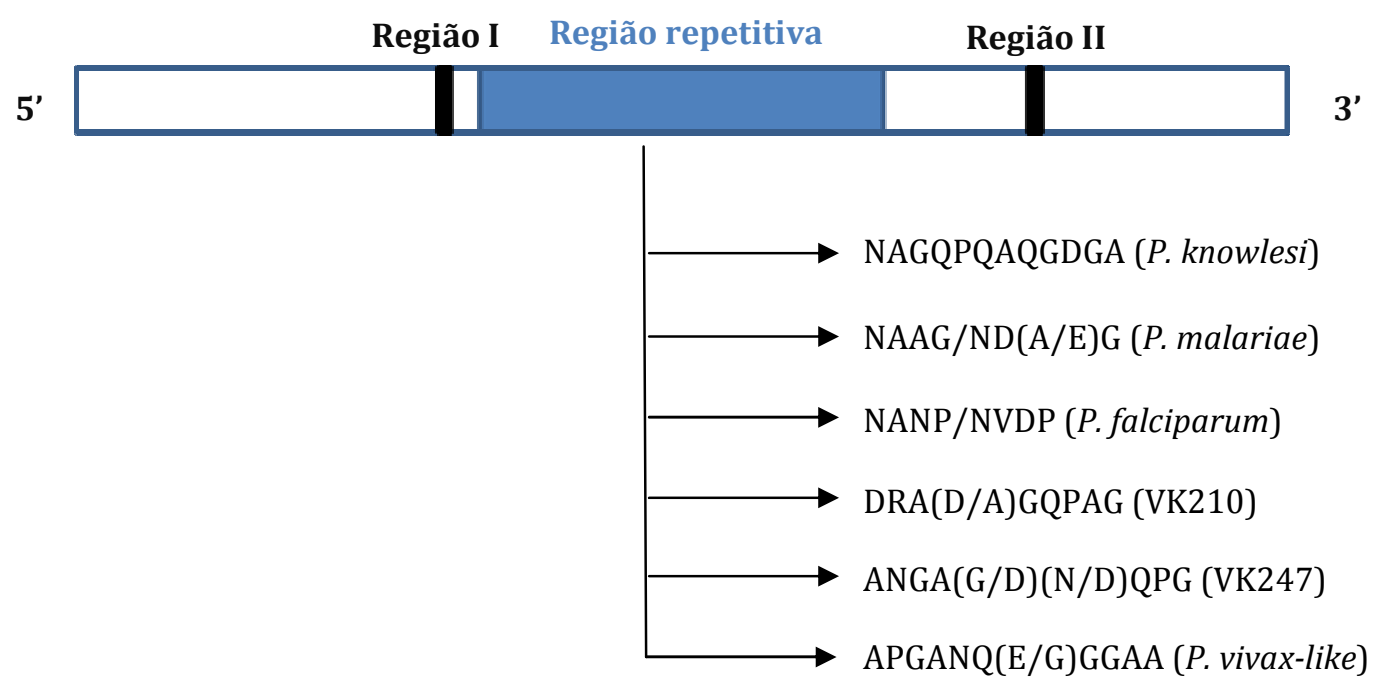

Figura 6 - Esquema do gene $C S$ e a sequência de aminoácidos codificada pela região central repetitiva dos parasitos da malária humana.

Fonte: Adaptada de QARI et al. (1994).

Diversos estudos foram realizados com o intuito de avaliar a distribuição global das variantes do P. vivax. O genótipo VK247 foi encontrado em áreas endêmicas da Tailândia (WIRTZ et al., 1990; KAIN et al., 1992, 1993a, 1993b), na América do Sul, na África (KAIN et al., 1991; GONZALEZ et al., 2001), no México e no Afeganistão (KAIN et al., 1992; RODRIGUEZ et al., 2000). Qari et al. (1993b) evidenciaram a ampla distribuição da variante $P$. vivax-like analisando 
amostras de sangue oriundas de regiões geográficas distantes como Papua Nova Guiné, Brasil, Indonésia e Madagascar.

A presença de anticorpos contra a CSP atesta a ocorrência de inoculação das formas infectantes pelos mosquitos. Estudos sorológicos evidenciaram a presença de anticorpos contra peptídeos sintéticos desenvolvidos a partir da sequência repetitiva do P. vivax-like em $33 \%$ de 80 soros de Papua Nova Guiné e em 24\% de 156 soros do Brasil (QARI et al., 1993b). Bonilla et al. (2006) promoveram a hibridização de sondas marcadas específicas para a variante $P$. vivax-like em 15 amostras de sangue de pacientes na Guiana, diagnosticadas como $P$. vivax. Este genótipo também foi detectado pela primeira vez no Leste da África, por Kimbi et al. em 2005, em população de crianças com idades entre 3 e 16 anos.

Em áreas brasileiras, foram identificadas as três variantes em amostras de sangue de habitantes do Estado de São Paulo (CURADO et al., 1995, 2006) e de comunidades indígenas da Amazônia brasileira (ARRUDA et al., 1996). OliveiraFerreira et al. (2004) também confirmaram a presença de anticorpos contra as mesmas em indivíduos provenientes do município de Candeia do Jamari, no Estado de Rondônia.

Por meio do diagnóstico molecular de $C S$ de $P$. vivax, estudos prévios confirmaram a presença das três variantes em nosso país a partir de amostras dos Estados de Rondônia, Amapá e do Pará, mostrando que a variante VK210 pode ser encontrada em infecções simples e em concomitância com as outras duas, enquanto a VK247 e a $P$. vivax-like foram detectadas apenas em infecções mistas (MACHADO e PÓVOA, 2000; MACHADO et al., 2003b). Recentemente, StortiMelo et al. (2009), analisando amostras de DNA obtidas a partir do sangue periférico de indivíduos residentes em cinco áreas da Amazônia brasileira, por PCR-RFLP, encontraram infecções contendo as três variantes isoladas e também em infecções mistas.

\subsection{Principais vetores do Brasil}


O gênero Anopheles Meigen, 1818 compreende no mínimo 484 espécies (HARBACH, 2004) distribuídas em sete subgêneros: Anopheles Meigen, 1818, Kerteszia, Nyssorhynchus Blanchard, 1902, Cellia Theobald, 1905, Stethomya Theobald, 1902, Lophopodomyia Antunes, 1937 e Baimaia Harbach, Rattanarithikul and Harrison, 2005 (HARBACH et al., 2005). Aproximadamente 50 delas são vetores de plasmódios e, destes, cerca de 20 são importantes transmissores de malária ao homem (PAGES et al., 2007). A distribuição geográfica dos anofelinos é ampla (Figura 7) podendo ser encontrados em diversos ambientes, desde desertos às florestas tropicais (KISZEWSKI et al., 2004).

No Brasil foi registrada a presença de 55 espécies de Anopheles spp. (REBELO et al., 2007) incluindo o subgênero Nyssorhynchus, principal responsável pela manutenção da malária na região Amazônica, enquanto Kerteszia destaca-se pela transmissão de plasmódio em áreas recobertas pela Floresta Atlântica (BRANQUINHO et al., 1997; FORATTINI, 2002).

O Anopheles darlingi Root, 1926 é o principal vetor da malária no Brasil e a transmissão da doença em diversos locais da região Amazônica está estreitamente vinculada à presença desta espécie. É um mosquito predominantemente sul-americano, com distribuição abrangendo desde o Sul do México até o Norte da Argentina (FORATTINI, 2002). O An. darlingi é altamente antropofílico, endofílico e apresenta taxas de sobrevivência maiores que de outros anofelinos presentes na Amazônia brasileira (KISZEWSKI et al., 2004). De fato, esta espécie é bastante susceptível aos plasmódios humanos e se adapta muito bem as alterações no ambiente, o que propicia um aumento de sua densidade (CONSOLI e OLIVEIRA, 1994) e a conseqüente manutenção da endemicidade em grau elevado.

Outras espécies estão relacionadas como transmissoras secundárias de plasmódios causadores da malária humana. Anopheles aquasalis Curry, 1932 é o principal vetor de malária na região costeira do Brasil, e atinge o litoral das Guianas, Venezuela e Colômbia devido a sua adaptação a ambientes de águas salobras e o fato de suas larvas suportarem alto teor de salinidade (FORATTINI, 
2002). Apresenta comportamento alimentar bastante variável. Na Amazônia brasileira, onde o clima é equatorial, o mosquito é preferencialmente zoófilo (GALVÃO et al., 1942) ao passo que no Nordeste, de clima semi-árido, é mais antropofílico (DEANE et al., 1948). Já no Sudeste do Brasil, cujo clima é semitropical, tem sido observado ora atacando o homem ora animais domésticos (LOURENÇO DE OLIVEIRA e HEYDEN, 1986; FLORES-MENDOZA et al., 1996). Tem sido incriminado como vetor da malária quando em elevada densidade, em certas épocas do ano (DEANE, 1986).

Anopheles albitarsis é um complexo de seis espécies crípticas, sendo três delas nomeadas, An. albitarsis sensu stricto Lynch-Arribálzaga, 1878, An. marajoara Galvão e Damasceno, 1942, An. deaneorum Rosa-Freitas, 1989, e as outras três não nomeadas, conhecidas como espécie $\mathrm{B}$, identificada pela metodologia de RAPD-PCR (WILKERSON et al., 1995a, WILKERSON et al., 1995b.), espécie E, diferenciada a partir do An. marajoara com base na análise do gene para a síntese da enzima citocromo oxidase I mitocondrial (LEHR et al., 2005) e espécie F, identificada a partir de sequências do segundo espaçador interno transcrito (ITS2) (BROCHERO et al., 2007). Seu território nas Américas corresponde ao nordeste da Argentina, todo o Uruguai, o Paraguai, o Brasil, a Venezuela e as Guianas; ocorre também na Colômbia, Panamá, Costa Rica, Honduras, Guatemala e Trinidad (CONSOLI e OLIVEIRA, 1994).

Embora observações de campo não caracterizassem An. albitarsis s. 1. como transmissor de malária, por ser um anofelino zoofílico e que raramente penetra nos domicílios (DEANE, 1948), estudos mais recentes consideram três espécies como importantes vetores da malária. O An. marajoara parece ser um dos principais vetores na Serra do Navio, Estado do Amapá (PÓVOA et al., 2001) e em Boa Vista, Estado de Roraima (SILVA-VASCONCELOS et al., 2002), e em Macapá, capital do Estado do Amapá, foi considerado o principal vetor de malária (CONN et al., 2002). Recentemente, a espécie E foi incriminada como importante transmissor da malária no Estado de Roraima (PÓVOA et al., 2006) e o $A n$. deaneorum também foi incriminado como vetor, a partir de infecções experimentais (KLEIN et al., 1991a, 1991b). 
O complexo Anopheles triannulatus é formado por no mínimo três espécies crípticas: An. triannulatus sensu stricto Neiva e Pinto, 1923, An. halophylus Silva-do-Nascimento e Lourenço de Oliveira, 2002 e uma espécie não nomeada, referida como An. triannulatus $\mathrm{C}$, que pode ser diferenciada a partir de análises isoenzimáticas (SILVA-DO-NASCIMENTO et al., 2006). Sua área de distribuição engloba principalmente a América do Sul, a leste da Cordilheira dos Andes, até o norte da Argentina (FORATTINI, 2002). O complexo é constituído essencialmente por espécies zoofílicas, exofílicas e crepusculares, podendo, porém invadir os domicílios quando em densidades muito altas, exercendo assim um papel secundário na transmissão da malária (BROCHERO et al. 2006, ROSAFREITAS et al. 2007).

O Anopheles nuneztovari Gabaldón, 1940 tipicamente, distribui-se pela região norte da América do Sul, incluindo a bacia do rio Amazonas (FORATTINI, 2002), onde é um importante vetor de malária (FAJARDO e ALZATE, 1987; RUBIO-PALIS et al., 1992; PÓVOA et al., 2001; GALARDO et al., 2007). São tidos classicamente como exofílicos e zoofílicos, embora alguns estudos tenham encontrado resultados controversos, com tais mosquitos apresentando considerável antropofilia e endofilia (RUBIO-PALIS et al., 1994; TADEI et al., 1998). Estudos morfológicos, comportamentais, citogenéticos e isoenzimáticos parecem evidenciar que An. nuneztovari seja um complexo de espécies (CONN et al., 1998; SCARPASSA et al., 1999, 2000). Conn (1990) e Conn et al. (1993) descreveram três citótipos baseados em polimorfismos cromossômicos. Mais recentemente, a partir de análises do gene white, Mirabello e Conn (2008) encontraram três linhagens distintas na Amazônia brasileira.

O Anopheles oswaldoi sensu stricto Peryassú, 1922 foi descrito baseado na morfologia de exemplares adultos coletados no Vale do Rio Doce, Estado do Espírito Santo, enquanto que o Anopheles konderi Galvão e Damasceno, 1942 foi descrito a partir da genitália de exemplares machos coletados no Estado do Amazonas. Acredita-se que estas duas espécies façam parte do complexo $A n$. oswaldoi juntamente com outras duas espécies cuja identificação ainda necessita ser melhor elucidada (MARRELLI et al., 1999; SCARPASSA e CONN, 2006). A 
presença atual deste mosquito vai desde a Costa Rica até o norte da Argentina do Uruguai (FORATTINI, 2002). Existem controvérsias quanto ao papel do $A n$. oswaldoi na transmissão da malária mas, em geral, é considerado um vetor secundário, embora tenha sido incriminado como principal vetor local de malária no Vale do rio Ene e no Vale Amazônico, no Peru (HAYES et al., 1987; NEED et al., 1993), em localidades da Venezuela (RUBIO-PALIS et al., 1992), além de localidades do Estado do Acre (BRANQUINHO et al., 1996; MARRELLI et al., 1998).

O Anopheles braziliensis Chagas, 1907 apresenta uma distribuição predominantemente no interior do continente sul-americano (FORATTINI, 2002), realiza seu repasto em seres humanos, mas são pouco antropofílicos, sendo mais zoofílicos com tendência a exofilia (OLIVEIRA-FERREIRA et al., 1992). A despeito de ter sido encontrado naturalmente infectado, é pouco provável que esta espécie tenha importante significado epidemiológico (DEANE et al., 1988; OLIVEIRA-FERREIRA et al., 1992).

$\mathrm{Na}$ região Extra-Amazônica, espécies do subgênero Kerteszia, notadamente o Anopheles cruzii Dyar e Knab, 1908 e o Anopheles bellator Dyar e Knab, 1906 são os principais responsáveis pelos casos de malária. As formas imaturas destes anofelinos criam-se nos verticilos das folhas das bromélias, o que justifica a distribuição destas espécies ao longo das áreas de Mata Atlântica. Estes anofelinos são incriminados na transmissão de $P$. vivax, bem como de parasitos de malária símia. Apresentam atividade ao longo das 24 horas do dia, com picos nos períodos crepusculares e embora sua competência vetorial seja baixa, a alta densidade de mosquitos e sua voracidade podem compensar a baixa porcentagem de espécimes infectados (BRANQUINHO et al., 1997). 


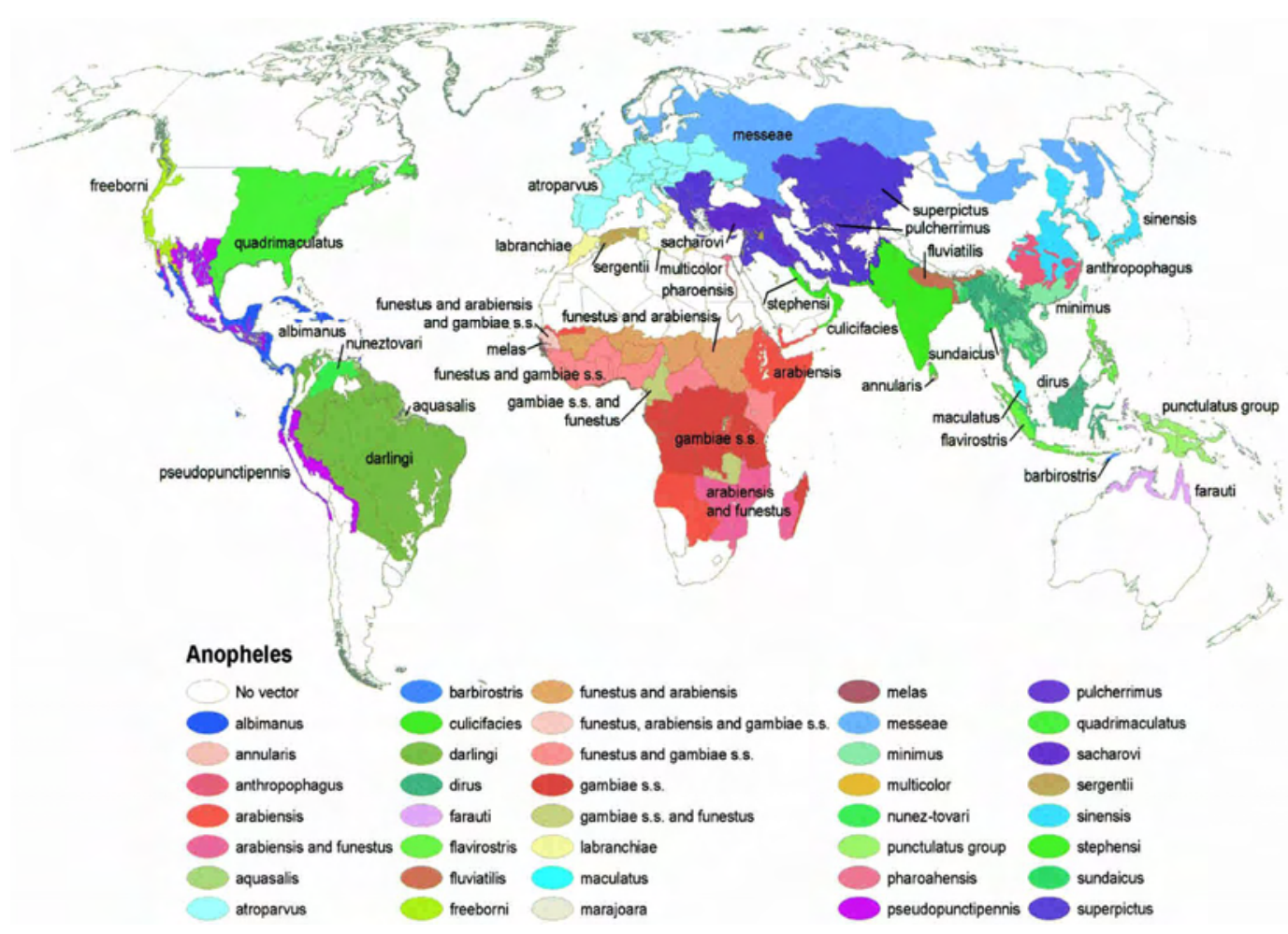

Figura 7 - Distribuição mundial das principais espécies de Anopheles vetores de Plasmodium humano.

Fonte: KISZEWSKI et al. (2004).

\subsection{Competência vetorial}

Diversos fatores relacionados ao parasito, ao vetor e ao hospedeiro interferem na dinâmica de transmissão da malária e nas susceptibilidades específicas de cada espécie de anofelino. Ao que parece, existem interações específicas entre as moléculas produzidas pelo parasito e as das células a serem invadidas (SINDEN, 2002). Isso poderia explicar o fato de espécies diferentes de Plasmodium serem veiculadas por anofelinos, também de espécies diferentes.

Em um experimento realizado por Rosenberg (1985), observou-se que esporozoítos de P. knowlesi são incapazes de invadir as glândulas salivares de An. freeborni Aitken, 1939. Os oocistos se desenvolviam normalmente e liberavam os esporozoítos, mas estes nunca eram encontrados nas glândulas salivares desta 
espécie de anofelino. Com o transplante das glândulas salivares do An. freeborni para o An. dirus Peyton e Harrison, 1979, uma espécie completamente susceptível a infecção por $P$. knowlesi, observou-se que também não ocorria a invasão das mesmas. Realizando-se o contrário, isto é, transplantando as glândulas do $A n$. dirus em An. freeborni, observou-se que o processo de invasão era completado.

Em áreas endêmicas do México, Gonzales-Ceron et al. (1999) observaram a susceptibilidade de An. albimanus Wiedemann e An. pseudopunctipennis Theobald a infecções determinadas pelas variantes VK210 e VK247, respectivamente, por meio de PCR e hibridização com sondas específicas para cada variante. Neste mesmo estudo, notaram que todos pacientes com infecções causadas pela variante VK210 eram residentes de regiões costeiras, onde o $A n$. albimanus é mais comum. No Pará, também foi reportada diferenças na susceptibilidade dos anofelinos às variantes, indicando que o An. darlingi e o $A n$. aquasalis são mais suscetíveis à infecção por VK210 (SILVA et al., 2006). Os autores sugerem que a maior probabilidade de esporozoítos VK210 se desenvolver nestas espécies comparado à VK247 possa ser determinada pela presença de mais gametócitos VK210 circulando nos pacientes ou por outros mecanismos, como a destruição de oocinetos e/ou a interrupção do desenvolvimento do oocisto, tal como observado em An. albimanus, que é resistente à infecção pela variante VK247 (GONZÁLEZ-CERON et al., 2001).

Em dois estudos realizados por Klein et al. (1991a, 1991b) comparando a susceptibilidade de diferentes espécies de Anopheles, verificou-se que, quando infectados experimentalmente por P. falciparum, An. costai Fonseca e Ramos apresenta competência equiparável ao An. darlingi que por sua vez possui competência maior que o An. deaneorum. O An. triannulatus s.l. e o An. oswaldoi s.l. apresentaram baixas taxas de infecção nas glândulas. O An. costai havia sido classificado como An. mediopunctatus, mas sua classificação como espécie foi revisto por Sallum et al. (1999). Quando infectados por P. vivax, o An. braziliensis e o An. benarrochi s.l. Gabaldon, Cova Garcia e Lopez mostraram-se refratários à infecção enquanto as outras cinco espécies que foram infectadas por P. falciparum também foram susceptíveis ao $P$. vivax. 
Silva-Vasconcelos et al. (2002) encontraram maiores taxas de infecção em An. darlingi $(8,5 \%)$ quando comparado com outras três espécies capturadas contendo infecção natural; An. albitarsis s.1. (4,6\%), An. braziliensis (3,0\%) e An. nuneztovari (2,0\%), sendo que apenas An. darlingi e An. albitarsis s. 1. continham infecções mistas. O $P$. vivax foi a espécie mais prevalente $(72,3 \%)$ seguido pelo $P$. falciparum $(26,1 \%)$ e $P$. malariae $(1,6 \%)$. O An. albitarsis s.l. foi a única espécie infectada pelas três espécies de Plasmodium.

A competência vetorial, mediante o encontro de infecção natural, tem sido verificada para o An. marajoara. Galardo et al. (2007) encontrou esta espécie infectada com P. falciparum, P. malariae e as variantes VK210 e VK247. Nas tentativas de infecção experimental, esse mosquito mostrou-se susceptível ao $P$. vivax com produção de esporozoítos nas glândulas salivares, porém, em relação ao P. falciparum, os resultados obtidos foram negativos (KLEIN et al., 1991a, 1991b).

O An. nuneztovari foi incriminado como vetor da variante VK210 em algumas áreas da região Amazônica (ARRUDA et al., 1986; TADEI et al., 1988) e das variantes VK210 e VK247, bem como de P. malariae no Estado do Amapá (PÓVOA et al., 2001; GALARDO et al., 2007). As razões para o alto número de indivíduos desta espécie ter sido encontrado infectado com a variante VK210 ainda não foram bem compreendidas, mas outras espécies de anofelinos mostraram diferenças na susceptibilidade às variantes do $P$. vivax (GONZALESCERON et al., 1999; SILVA et al., 2006). Ainda, esta variante é a mais amplamente distribuída na região Amazônica (STORTI-MELO et al., 2009) e foi associada com maiores níveis de parasitemia em humanos quando comparada com as variantes VK247 e P. vivax-like (MACHADO e PÓVOA, 2000), o que poderia justificar tal associação. Sua participação na transmissão de $P$. falciparum ainda não está bem estabelecida, embora tenha sido encontrado infectado com esta espécie nos Estados de Roraima, Pará (PÓVOA et al., 2001), Amapá (PÓVOA et al., 2001; GALARDO et al., 2007) e Amazonas (TADEI e DUTARYTHATCHER, 2000). 
O An. triannulatus s.l. foi encontrado infectado pelas três espécies circulantes no Brasil, inclusive para as variantes VK210 e VK247 (GALARDO et al., 2007) e diversos autores encontraram esta espécie naturalmente infectada por P. falciparum em diferentes áreas da Região Amazônica, embora este anofelino não tenha sido considerado importante transmissor de malária (ARRUDA et al., 1986; TADEI e DUTARY-THATCHER, 2000; PÓVOA et al., 2001). Já se constatou a competência de An. deaneorum em transmitir malária Em tais observações pode-se constatar a positividade de $2,76 \%$ para $P$. falciparum, $0,55 \%$ para $P$. vivax variante VK210 e de $0,82 \%$ para a variante VK247 (BRANQUINHO et al., 1993; MARRELLI et al., 1998).

Em áreas remanescentes de Mata Atlântica do Estado de São Paulo, Branquinho et al. (1997) verificaram um baixo índice de infecção em An. cruzii com a utilização de anticorpos monoclonais dirigidos contra as regiões repetidas da CSP de VK210, VK247 e P. malariae.

\subsection{Métodos para a identificação dos plasmódios em anofelinos}

Um dos principais parâmetros analisados para o controle e monitoramento da malária é a detecção de espécies de Plasmodium nos vetores capazes de infectarem humanos. Por muitos anos a técnica utilizada para definir a infecção dos mosquitos foi o exame direto do estômago e das glândulas salivares, seguida da observação dos oocistos e esporozoítos por microscopia. Embora esta metodologia seja bastante confiável, ela apresenta algumas limitações, tais como a necessidade de microscopistas bem treinados, empregar mosquitos mortos recentemente, consumir muito tempo e ser incapaz de definir a espécie de plasmódio envolvida na infecção (LI et al., 2001).

Um grande avanço foi a demonstração da existência de antígeno específico de esporozoítos, proveniente da CSP. O seqüenciamento desta proteína e de seu gene correspondente evidenciou a existência de sequências repetitivas específicas 
para algumas espécies de Plasmodium (OZAKI et al., 1983; DAME et al., 1984; ARNOT et al., 1985; LAL et al., 1988) possibilitando assim distinguir várias espécies de Plasmodium por meio de testes de ELISA (do inglês "Enzyme Linked ImmunonoSorbent Assay"), utilizando anticorpos monoclonais (mAbs) contra esta região repetitiva (WIRTZ et al., 1987).

O CS-ELISA apresenta alta sensibilidade e especificidade e esta metodologia vem sendo amplamente empregado (SATTABONGKOT et al., 2004; HASAN et al., 2009). Entretanto, tem sido evidenciado que o CS-ELISA pode superestimar as reais taxas de infecção das glândulas salivares (BEIER e KOROS, 1991; FONTENILLE et al., 2001), falha na detecção de esporozoítos imaturos nos oocistos (HASAN et al., 2009) e apresenta baixa sensibilidade quando poucos esporozoítos estão presentes (APPAWU et al., 2003). Além disso, o CS-ELISA não é apropriado para material preservado em etanol e requer que cada teste seja realizado separadamente para cada espécie analisada (WIRTZ et al., 1987; WIRTZ et al., 1992). Atualmente, não tem sido desenvolvido mAbs para o $P$. malariae e o P. vivax-like, existindo ainda a possibilidade de, em breve, não serem mais produzidos comercialmente os mAbs disponíveis para a identificação das espécies de Plasmodium (Póvoa, comunicação pessoal).

Vários pesquisadores têm adaptado os reagentes de ELISA para ensaios de dot-blot e dipsticks com o intuito de fornecer ferramentas práticas para rápida aplicação em trabalhos de campo. Ryan et al. (2001) desenvolveram o painel de Antígeno VecTest Malaria (VecTest ${ }^{\mathrm{TM}}$ ). Este teste determina a presença ou ausência de epítopos da proteína CS específicos de $P$. falciparum e duas variantes de $P$. vivax (VK210 e VK247), oferecendo vantagens práticas para trabalhos em campo, como o fato de não necessitar de equipamento de refrigeração para estocagem dos reagentes. Bangs et al. (2002) reportaram que a performance do VecTest ${ }^{\mathrm{TM}}$ foi comparável ao teste de ELISA em amostras da Indonésia e Papua Nova Guiné. Porém, embora os testes imunocromatográficos usados para detecção do Plasmodium sejam de fácil manuseio, podendo produzir resultados rápidos, eles geralmente possuem menor especificidade e sensibilidade quando comparados com o diagnóstico molecular (MORENO et al., 2004). 


\subsubsection{Métodos moleculares aplicados a detecção de Plasmodium}

De acordo com os objetivos do trabalho, em se tratando de pesquisa clínica ou ambiental, ou se diagnóstico clínico, ambiental ou epidemiológico, a PCR (Polymerase Chain Reaction - Reação em Cadeia da Polimerase) foi a técnica de maior impacto aplicada no estudo da sistemática e ecologia dos parasitos, em particular em diagnóstico, taxonomia, evolução biológica, genética de populações e interações com seus hospedeiros (SNOUNOU et al., 1993; GARROS et al., 2004; SOULAMA et al., 2009).

Esta se baseia na amplificação in vitro de moléculas de DNA, utilizando dois iniciadores (MULLIS e FALOONA, 1987) e uma DNA polimerase termoestável (SAIKI et al., 1988). Os iniciadores apresentam normalmente 18-30 pb, possuem a extremidade 3'-OH livre e são complementares às sequências flanqueadoras do segmento alvo (BOWDITCH et al., 1993), permitindo o início da amplificação da sequência de DNA pela enzima DNA polimerase, gerando grandes quantidades de DNA de segmentos específicos do genoma (FERREIRA e GRATTAPAGLIA, 1996).

A PCR-RFLP (do inglês "Restriction Fragment Length PolymorfismPolimerase Chain Reaction") é uma adaptação do RFLP que envolve a amplificação de genes ou regiões específicas do genoma via PCR e posterior clivagem com endonucleases, gerando polimorfismos quanto ao peso molecular, dispensando o uso de reagentes radioativos. Cada enzima de restrição possui um sítio específico de reconhecimento, onde é realizada a clivagem. Geralmente, essas sequências são simétricas e possuem 4 a 6 pares de bases. A escolha das enzimas de restrição a serem utilizadas pode ser realizada pela digestão dos produtos de PCR com um grande número de enzimas ou através da análise da sequência do gene ou região de interesse. Em estudos entomológicos, a PCRRFLP tem sido utilizada para estudo do DNA mitocondrial e ribossômico visando, principalmente, a identificação de espécies (BEEBE et al., 2000; VAN BORTEL et al., 2000, 2002; FANELLO et al., 2002; GARROS et al., 2004). 
De modo a garantir que as técnicas de PCR alcancem elevados níveis de sensibilidade e especificidade, deve-se padronizar o protocolo de modo a evitar problemas de execução tais como o aparecimento de bandas inespecíficas, ausência de bandas na visualização do gel, contaminações e impurezas das amostras. A seleção dos reagentes e das condições da reação de PCR tem sido fundamental para a identificação de Plasmodium nos vetores. As principais condições que influenciam o desempenho da reação de PCR são o desenho e concentração dos iniciadores (OYEDEJI et al., 2007), os métodos de estocagem dos mosquitos (BASS et al., 2008) e fundamentalmente o processo de extração de DNA (LARDEUX et al., 2008).

Uma vantagem adicional do diagnóstico por PCR é sua capacidade de identificar os esporozoítos até a categoria de espécie. Além disso, esta metodologia apresenta sensibilidade e especificidade maior quando comparada com outras metodologias não moleculares. A PCR tem demonstrado, tanto em amostras de sangue quanto de mosquitos, como a prevalência dos parasitos de malária pode ser subestimada por microscopia (SNOUNOU et al., 1993). Os resultados obtidos por Wilson et al. (1998) indicam que o PCR pode ser até três vezes mais sensível do que o exame microscópico na identificação dos esporozoítos em glândulas salivares de mosquitos.

Póvoa et al. (2000) conduziram um estudo utilizando o método de PCRELISA para amplificar o gene da CSP e confirmar a detecção de parasitos da malária em mosquitos já identificados pelo teste de ELISA. Observaram que este método foi mais sensível que o ELISA, identificando outras espécies presentes em infecções mistas que não haviam sido detectadas. Além disso, Moreno et al. (2004) encontraram, uma taxa de esporozoítos de P.falciparum menor pelo VecTest $^{\mathrm{TM}}(3,27 \%)$ do que pela PCR $(16,0 \%)$, demonstrando como pode variar a taxa de infecção, condicionada pelo tipo de teste empregado.

Recentemente, Bass et al. (2008) propuseram o método de PCR em tempo real utilizando sondas TaqMan, para detecção de quatro espécies de Plasmodium humano ( $P$. falciparum, $P$. vivax, $P$. malariae e $P$. ovale) nos vetores, discriminando o P. falciparum das outras espécies, baseado em SNPs (do inglês 
"Single Nucleotide Polymorphism") no gene da subunidade menor do RNA ribosomal. Esse formato se caracteriza por uma reação de PCR acoplada à detecção em tempo real das moléculas amplificadas, à medida que elas são produzidas, através do monitoramento da emissão de fluorescência. Esta metodologia parece ser bastante promissora, uma vez que este método foi no mínimo tão sensível quanto a nested-PCR desenvolvida por Snounou et al. (1993).

Com o intuito de aumentar a sensibilidade do teste, a nested-PCR realizando duas rodadas de PCR pode ser empregada, como é o caso da metodologia desenvolvida por Snounou et al. (1993), que atualmente é amplamente considerada como padrão-ouro para detecção de espécies de Plasmodium (BASS et al., 2008). No entanto, uma significativa desvantagem da nested-PCR é a necessidade da realização de duas etapas, o que demanda mais tempo e aumenta os custos.

\subsection{Hipótese}

É possível reconhecer as espécies e variantes da malária humana em Anopheles, por meio de uma metodologia molecular. Esta estratégia pode ser utilizada para beneficiar o entendimento da epidemiologia da malária, auxiliando no controle de transmissão da doença. Para isso o gene $C S$ será amplificado por PCR, devido ao fato de variações na região central deste gene caracterizar as variantes do $P$. vivax. 
Objetivos 


\section{OBJETIVOS}

\subsection{Objetivos}

- Padronizar uma PCR para determinação da infecção em Anopheles pelo $P$. malariae, $P$. falciparum e pelo $P$. vivax.

- Padronizar uma PCR-RFLP que permita identificar as três variantes do $P$. vivax.

- Avaliar a concordância existente entre as técnicas de nested-PCR e PCRRFLP, verificando a sensibilidade e especificidade da metodologia desenvolvida. 
Capítulo 1 


\title{
3. Capítulo 1
}

\section{Detection of human malaria parasite in Anopheles Mosquitoes by PCR-RFLP using specific sequences on circumsporozoite gene}

\author{
Gustavo Capatti Cassiano ${ }^{1, \S}$, Luciane Moreno Storti-Melo ${ }^{1}$, Marinete \\ Marins Póvoa ${ }^{2}$, Allan Kardec Ribeiro Galardo ${ }^{3}$, Andréa Regina Baptista Rossit ${ }^{4}$, \\ Ricardo Luiz Dantas Machado ${ }^{4}$
}

${ }^{1}$ Departamento de Biologia, Universidade Estadual Paulista "Júlio Mesquita Filho", São José do Rio Preto, São Paulo State, Brazil,

${ }^{2}$ Instituto Evandro Chagas, MS/SVS, Ananindeua, Pará State, Brazil,

${ }^{3}$ Departamento de Zoologia, Seção de Entomologia Médica, Instituto de Pesquisas Científicas e Tecnológicas do Estado do Amapá, Amapá State, Brazil,

${ }^{4}$ Centro de Investigação de Microrganismos, Departamento de Doenças Dermatológicas, Infecciosas e Parasitárias, Faculdade de Medicina de São José do Rio Preto, São Paulo State, Brazil.

§Corresponding author: Tel/Fax: +55 1732015736

E-mail Address: gcapatti@ hotmail.com

\begin{abstract}
Introduction: The identification of the Plasmodium species in Anopheles mosquitoes is an integral component for the malaria control. There are some PCRbased assays for this purpose, but most only are able to discriminate the $P$. falciparum from other Plasmodium species. Moreover, none of these is concerned with the identification of $P$. vivax variants. We development a sensitive
\end{abstract}


polymerase chain reaction-repeated fragment length polymorphism (PCR-RFLP) method for detection of the human malaria parasites in Anopheles mosquitoes.

Methods: A PCR was development to identify $P$. falciparum, $P$. malariae and $P$. vivax, targeting the CSP gene. A PCR-RFLP was used to distinguish the $P$. vivax variants VK210, VK247 and P. vivax-like. The new PCR assay was compared against a nested PCR using artificially infected Anopheles mosquitoes.

Results: A total of 90 mosquitoes were artificially infected with $P$. vivax $(\mathrm{n}=30)$, $P$. falciparum $(\mathrm{n}=30)$ and $P$. malariae $(\mathrm{n}=30)$. These infected mosquitoes along with another 30 unfed mosquitoes were checked for the identification of Plasmodium by nested PCR and with the CS-PCR. Nested PCR for P. vivax, P. falciparum and $P$. malariae detected positive infection in 19, 16 and 21 mosquitoes respectively; whereas CS-PCR detected in 17, 14 and 16 mosquitoes, respectively. The comparison revealed a close agreement between the two assays ( $\kappa=0.723,0.867$ and 0.657 , respectively for $P$. vivax, $P$. falciparum and $P$. malariae groups). Subsequently, PCR-RFLP efficiently discriminate $P$. vivax variants VK210, VK247 and $P$. vivax-like.

Conclusions: This study describes a new assay that effectively detects $P$. vivax, $P$. falciparum and $P$. vivax variants. This assay may be employed to improve the understanding of malaria transmission dynamics by Anopheles species.

\section{Introduction}

The correct identification of the human-specific Plasmodium species in the mosquito host is an essential component for planning and monitoring of malaria control operations. According to the Brazil Ministry of Health (BRASIL, 2009), $P$. vivax is the predominant species in this country ( $83.5 \%$ of all cases) followed by $P$. falciparum (15.47\%), mixed species infection (1.0\%) and P. malariae $(0.03 \%)$. Moreover, the P. vivax circumsporozoite protein (CS) genotypes, VK210, VK247 and P. vivax-like, has been found in different Brazilian Amazon 
regions, in pure and mixed infections (MACHADO e PÓVOA, 2000; STORTIMELO et al., 2009). Additionally, these different human malaria species may differ on infectivity of anophelines (GONZALES-CERON et al., 1999), transmission potential and responses to anti-malarial drugs (MACHADO et al., 2003). Therefore, knowledge of the geographical distribution of the parasite species, as well as knowledge of vector species which are implicated in the transmission of malaria is important for the interpretation of epidemiological data.

For many years, the detection of malaria parasites in mosquitoes have been performed by dissection and visualization of the midgut and salivary glands under microscope. Although the microscopical examination is reliable, it demands fresh materials, requires experienced microscopists and is time consuming. Another limitation of this methodology is that it does not determine which Plasmodium species is present. A breakthrough was the discovery of specific antigens from the CS protein. The sequencing of this protein and its corresponding gene revealed the existence of specific repetitive sequences for some species of Plasmodium (OZAKI et al., 1983; DAME et al., 1984; ARNOT et al., 1985; LAL et al., 1988), allowing to distinguish different Plasmodium species by enzyme-linked immunosorbent assay (CS-ELISA) using monoclonal antibodies against the repetitive region (WIRTZ et al., 1987). The sensibility and specificity of CSELISA is high and it has been widely adopted (SATTABONGKOT et al., 2004; HASAN et al., 2009). However, there are some limitations in using this approach since it has been reported an overestimation of true salivary gland infection rates (ROBERT et al., 1988; FONTENILLE et al., 2001), false positive results (HASAN et al., 2009) and failure to detect low-level infections AREZ et al., 2000). Ryan et al. (2001) developed a rapid dipstick assay (VecTest ${ }^{\mathrm{TM}}$ Malaria), which determines the presence or absence of specific peptide epitopes of CS protein of $P$. falciparum and both $P$. vivax genotypes VK210 and VK247, but showed low sensibility when compared with the PCR (MORENO et al., 2004).

PCR-based assays have been shown to be the most efficient method for the identification of human malaria parasites (SNOUNOU et al., 1993a; 1993b). The results presented by Wilson et al. (1998) revealed that PCR can be up to three 
times more sensitive than direct observation of sporozoites in mosquito salivary glands under microscope. Recently, a real-time TaqMan PCR assay (BASS et al., 2008) and a novel single step PCR assay based on mitochondrial cytochrome b (Cyt b) gene (HASAN et al., 2009) were developed. These methods proved to be sensitive and specific for determine the infectivity in mosquitoes. However, they are only able to distinguish $P$. falciparum from other Plasmodium species. Currently, the most widely used PCR assay is a nested-PCR designed by Snounou et al. (1993b) using de small subunit ribosomal RNA, generally accepted as the gold standard' for human malaria species identification.

Hereby, we describe a novel PCR test using primers against specific regions in the sequences on $C S$ gene to identify human Plasmodium species, including $P$. vivax genotypes in the mosquito vector (CS-PCR/RFLP).

\section{Materials and Methods}

\section{Preparation of mosquito samples}

Laboratory-infected mosquitos were kindly provided by Dr Alexandre Oliveira at Malaria Branch, Division of Parasitic Diseases, Centers for Disease Control and Prevention. Anopheles dirus mosquitoes were artificially infected with $P$. vivax or $P$. falciparum and An. gambiae mosquitoes were artificially infected with $P$. malariae. Mosquitoes were storage on silica gel before being frozen at $-20^{\circ} \mathrm{C}$.

\section{Extraction of malaria parasite DNA from mosquitoes and plasmid clones}

DNA was extracted from individual mosquitoes using DNAzol (Invitrogen, U.S.A.) methods with slight modifications. Briefly, the head and thorax of single mosquitoes were placed in $1.5 \mathrm{~mL}$ Eppendorf tubes and macerated using a new sterile pipette tip in $100 \mu \mathrm{L}$ of DNAzol and the DNA extraction was continued as mentioned in the protocol. The product was suspended in $100 \mu 18 \mathrm{mM} \mathrm{NaOH}$ and stored at $-20^{\circ} \mathrm{C}$ until use. 
Three plasmid clones carrying a PCR insert of the CS gene amplified from $P$. vivax variants VK210, VK247 and $P$. vivax-like (BlueScript, Stratagene, U.S.A.), were kindly provided by Dr Ira Goldman at the Center for Disease Control and Prevention and used for PCR-RFLP standardization.

\section{Primer design}

We designed a PCR reaction to amplify the conserved region of the CS gene of $P$. falciparum and $P$. malariae and to amplify the internal variable region of the $C S$ gene of $P$. vivax. The sequence of $P$. falciparum was amplified using primer pairs PFCSP1 (5' CCAGTGCTATGGAAGTTCGTC 3') and PFCSP2 (5' CCAATTTTCCTGTTTCCCATAA 3’). We used primer pairs PMCSP1 (5'ATATAGACTTGCTCCAACATGAAGAA 3') and PMCSP2 (5'AATGATCTTGATTCGTGCTATATCTG 3') for P. malariae and primer pairs PVCSP1 (5’ AGGCAGAGGACTTGGTGAGA $\left.3^{\prime}\right)$ and PVCSP2 (5’ CCACAGGTTACACTGCATGG 3') for $P$. vivax. The primers were selected using web-based software Primer3 v.0.4.0 (http://www-genome.wi.mit.edu/cgi-bin/primer/primer3.cgi). A conformational analysis was made to investigate the possibility of primer secondary structures formations, self-complementary, annealing temp and GC

content using the software Primer3 and IDT OligoAnalyzer 3.1 (http://www.idtdna.com).

Nucleotide alignment of the $C S$ gene sequences of these human Plasmodium species of diverse geographic origin available in the National Center for Biotechnology Information (NCBI) (http://www.ncbi.nlm.nih.gov/BLAST/) database was performed to ensure there was no variation in the annealing region of primers.

\section{PCR amplification}

All PCR amplifications were carried out in a $25 \mu \mathrm{L}$ reaction mixture containing $3 \mu \mathrm{l}$ DNA template for $P$. falciparum and $P$. vivax and $5 \mu \mathrm{L}$ for $P$. malariae, 1 x PCR buffer (20 mM Tris- $\mathrm{HCl} \mathrm{pH} 8.4,50 \mathrm{mM} \mathrm{KCl}), 1.5 \mathrm{mM} \mathrm{MgCl}$, $0.2 \mathrm{mM}$ of each dNTP and $2.5 \mathrm{U}$ of Taq polymerase (Invitrogen, U.S.A.). Only 
the primers corresponding to each species were used in reaction mixture. A separate reaction was carried out with every sample for the detection of each species. The amplification was performed in a thermal cycler (DNA MasterCycler, Eppendorf, Germany) included to an initial cycle of $94^{\circ} \mathrm{C}$ for 15 min, followed by 30 cycles of $94^{\circ} \mathrm{C}$ for $1 \mathrm{~min}, 58^{\circ} \mathrm{C}$ for $1 \mathrm{~min}$ and $72^{\circ} \mathrm{C}$ for $1 \mathrm{~min}$, then a final extension at $72^{\circ} \mathrm{C}$ for $10 \mathrm{~min}$. Positive controls were DNA of $P$. falciparum, $P$. malariae and $P$. vivax. Sterilized water and DNA extracted from colonized, malaria-free, Anopheles darling were used as a negative control. The internal transcribed spacer 2 (ITS2) region of Anopheles was amplified using the protocol from Kampen (2005) and used as an internal DNA extraction control.

\section{PCR product analysis}

Five $\mu \mathrm{L}$ PCR product was electrophoresed at $100 \mathrm{~V}$ for $50 \mathrm{~min}$ with 50 or 100 bp DNA molecular weight markers (Invitrogen, U.S.A.) in 1.5\% agarose gel stained by ethidium bromide and the target DNA was visualized on an ultraviolet transilluminator.

\section{Sensitivity of the assay}

DNA samples for the $P$. falciparum, $P$. malariae and $P$. vivax were diluted in series to determine the sensitivity of PCR assay. These samples were diluted to $10 \mathrm{ng} / \mu \mathrm{L}$ in sterile water (determined using a NanoDrop® ND-1000 UV-Vis spectrophotometer) and then serial dilutions were made down to 1 in $1 \times 10^{6}$.

\section{Specificity of the assay}

To define the specificity of the PCR, were used positive genomic DNAs obtained from patients' blood with $P$. vivax, $P$. falciparum and $P$. malariae. In addition, DNA from Anopheles stephensis infected with P. ovale, Anopheles gambiae infected with P. malariae, Anopheles dirus infected with P. falciparum and $P$. vivax, as well as from negative Anopheles darling, were used to confirm the PCR specificity. 


\section{Restriction digests of PCR products}

$P$. vivax variants were typed by RFLP analysis. The enzymes were selected using the software RestrictionMapper (http://www.restrictionmapper.org/). PCR products from all variants have at least one cleavage site. The restriction reaction was performed in a final volume of 20 $\mu \mathrm{L}$, using $1 \mu \mathrm{L}$ of Cac8I (New England Biolabs, U.S.A.) or $1 \mu \mathrm{L}$ of AluI (Invitrogen, U.S.A.), $2 \mu \mathrm{L}$ of recommended restriction buffer, $10 \mu \mathrm{l}$ of the PCR product and $7 \mu \mathrm{l}$ of sterilized water. Reactions took place at $37^{\circ} \mathrm{C}$ for $1 \mathrm{~h}$. Digested products were electrophoretically separated on $12.5 \%$ polyacrylamide gels, in the presence of 50 and 100 bp DNA molecular weight markers (Invitrogen, U.S.A.) and the gels were subsequently silver stained.

\section{Nested PCR}

The amplification of Plasmodium DNA was carried out as described previously by Snounou et al (1993b).

\section{Statistical analysis}

Statistical comparison between $C S$-PCR and the nested PCR was made using Cohen's Kappa measure of test association. Analyses were performed using the BioEstat program version 5.0 (AYRES et al., 2000).

\section{Results}

\section{Amplification of the $P$. malariae, $P$. falciparum and $P$. vivax variants $\mathrm{CS}$ gene} fragment

As show in Figure 8, the size of fragments amplified of plasmids corresponds to 789 bp for $P$. vivax variant VK210 and 834 bp for $P$. vivax variants VK247 and $P$. vivax-like. PCR products had lengths of $199 \mathrm{bp}$ for $P$. malariae and 118 bp for $P$. falciparum in $1.5 \%$ agarose gel. 


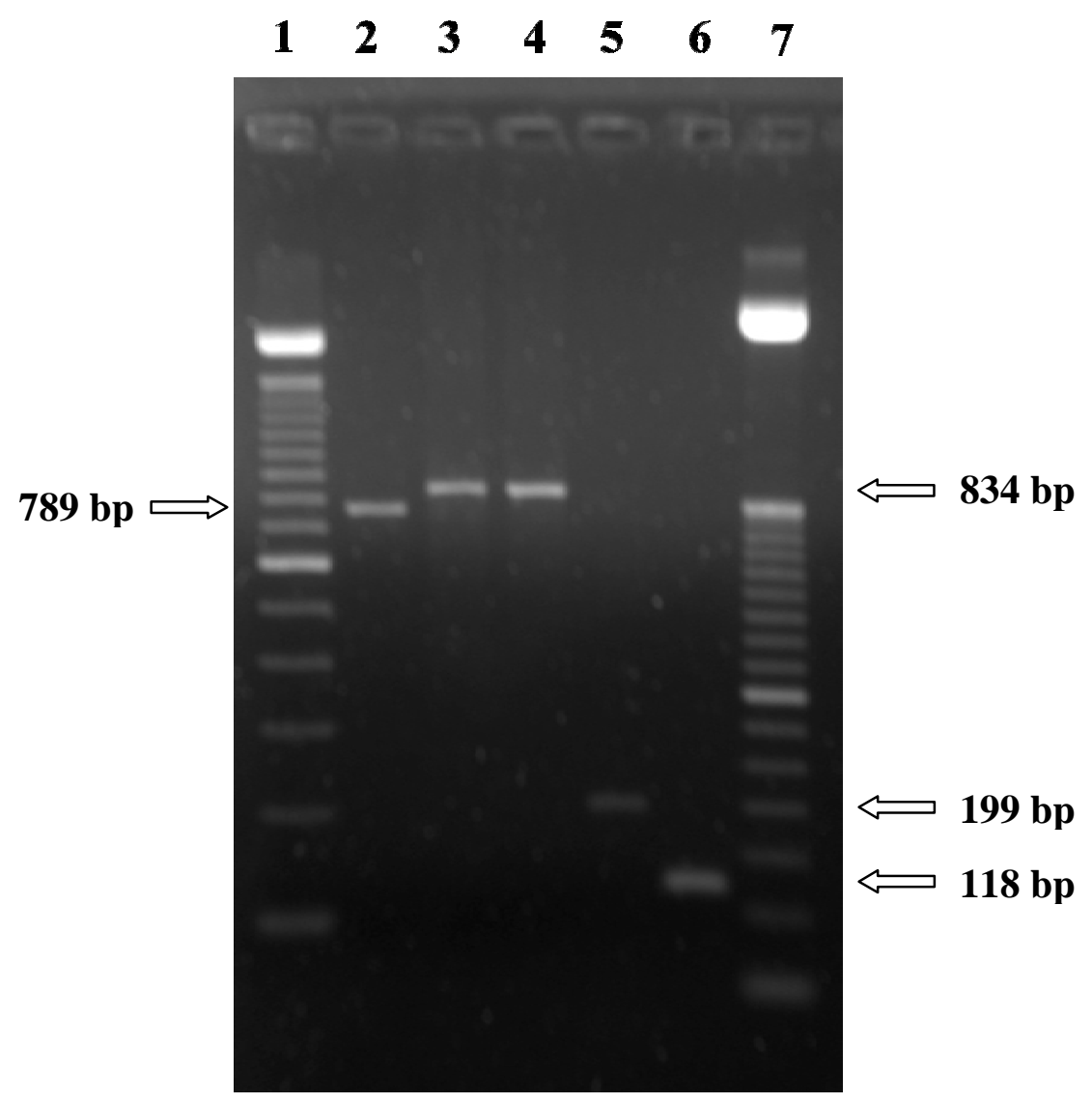

Figure 8. Banding pattern of the $\boldsymbol{C S}$-PCR. Lane 1, 100 bp DNA ladder (Invitrogen, U.S.A.); Lane 2, VK210 plasmid; Lane 3, VK247 plasmid; Lane 4, $P$. vivax-like plasmid; Lane 5, P. malariae; Lane 6, P. falciparum; Lane 7, 50 bp DNA ladder (Invitrogen, U.S.A.). Band sizes from 2 to 6, 789, 834, 834, 199, and $118 \mathrm{bp}$, respectively.

\section{Sensitivity of $C S$-PCR}

The sensibility of the CS-PCR was assessed by serial dilutions of Plasmodium genomic DNA of the P. malariae, P. falciparum and P. vivax. The CS-PCR showed a sensibility for $P$. vivax at a 1:10,000 dilution, for $P$. falciparum was at 1:5,000 dilution and for P. malariae at a 1:1,000 dilution (Figure 9). 


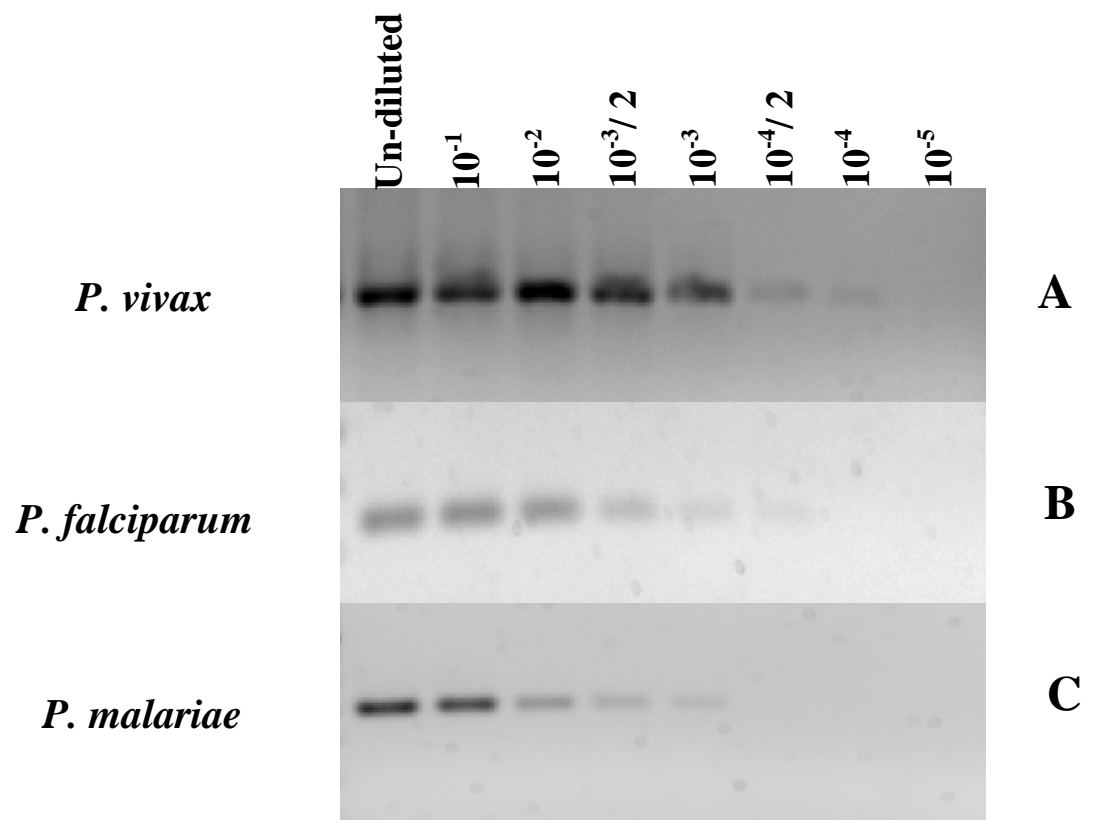

Figure 9. Sensitivity of the $\boldsymbol{C S}$-PCR. The dilution of the original $10 \mathrm{ng} / \mathrm{uL}$ DNA template to $10^{-5} \mathrm{ng} / \mathrm{uL}$. (A) Dilution for P. vivax. (B) Dilution for P. falciparum. (C) Dilution for P. malariae. Electrophoresis was in a $1.5 \%$ agarose gel.

\section{Specificity of $C S$-PCR}

Control genomic DNAs from $P$. malariae, $P$. falciparum and $P$. vivax as well as from Anopheles stephensis infected with $P$. ovale and unfed mosquitoes were used to confirm the specificity of each primer pair. No amplification was observed when we used DNA from another species of Plasmodium that is not the target species of each primer pair. The CS-PCR not amplifies any Anopheles gene (Figure 10). 


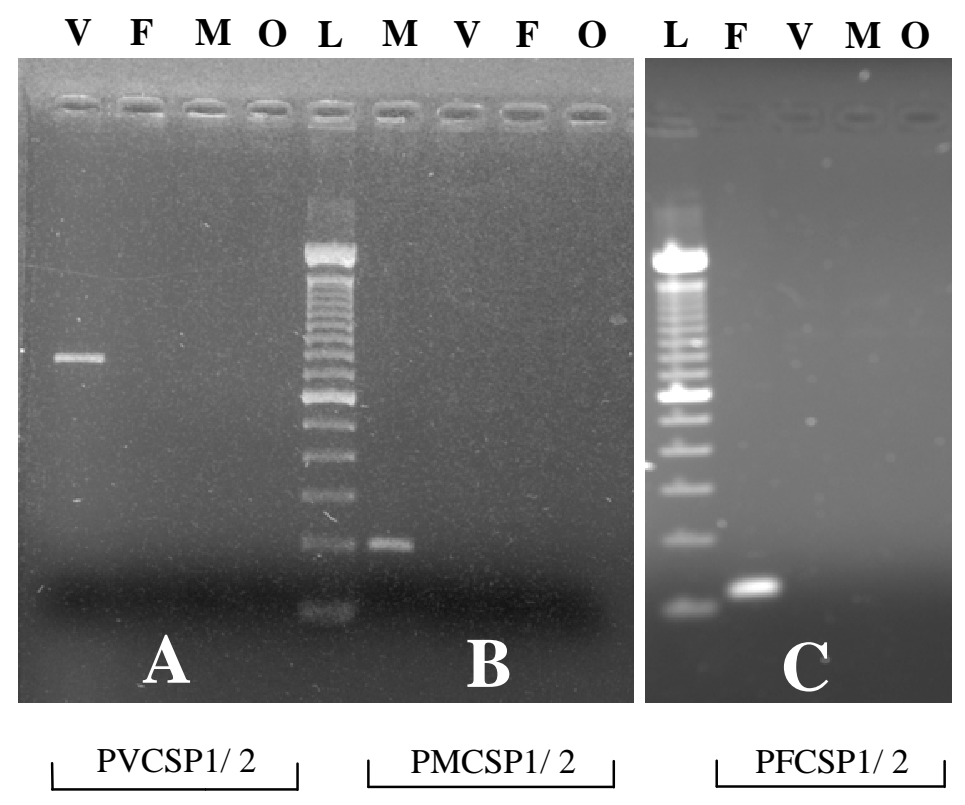

Figure 10. Specificity of the amplification assays. Amplification of the products of PCR using the indicated primer pairs. (A) A fragment specific for P. vivax. (B) A fragment specific for $P$. malariae. (C) A fragment specific for P. falciparum. V: P. vivax; F: P. falciparum; M: P. malariae; O: P. ovale; L:100 bp ladder as molecular size marker. Electrophoresis was in a $1.5 \%$ agarose gel.

\section{Evaluation of the CS-PCR}

The CS-PCR and the nested PCR were tested in mosquitoes artificially infected. A total of 120 mosquitoes were screened, consisting of 30 infected with $P$. vivax, 30 infected with $P$. falciparum, 30 infected with $P$. malariae and 30 unfed mosquitoes. The results are show in Table 1. Of the 30 mosquitoes infected with $P$. vivax, 17 were scored positive by $C S$-PCR and 19 were scored positive by nested PCR. A total of 14 mosquitoes of the P. falciparum group were positive by CS-PCR and 16 were positive by nested PCR. Of the 30 mosquitoes infected with P. malariae, 16 were scored positive by $C S$-PCR and 21 were scored positive by nested PCR. All mosquitoes positives assessed for their infection rates using CSPCR were detected using nested PCR, except one mosquito scored positive for $P$. vivax. Finally, no infection was found in any of the 30 unfed mosquitoes using 
both methods. The comparison revealed a close agreement between the 'gold standard' nested PCR and CS-PCR $(\kappa=0.723,0.867$ and 0.657 , respectively for P. vivax, P. falciparum and P. malariae).

Table 1. Results of the $C S$-ELISA and nested PCR using artificially infected mosquitoes

\begin{tabular}{lcccc}
\hline & CS-PCR & \multicolumn{3}{c}{ Nested PCR } \\
\hline & Positive & Negative & Positive & Negative \\
\hline Mosquitoes infected with P. vivax & 17 & 13 & 19 & 11 \\
\hline Mosquitoes infected with P. falciparum & 14 & 16 & 16 & 14 \\
\hline Mosquitoes infected with P. malariae & 16 & 14 & 21 & 09 \\
\hline Uninfected mosquitoes & 0 & 30 & 0 & 30 \\
\hline
\end{tabular}

\section{PCR-RFLP analysis}

The product amplified with the pair primers PVCSP1 and PVCSP2 to identification of $P$. vivax was subjected to RFLP. The patterns observed with the Cac8I enzyme are show in Figure 11. PCR-RFLP for $P$. vivax variant VK210 showed fragments of 168, 135, 81 and $27 \mathrm{bp}$. The digest of products of the $P$. vivax variants VK247 showed fragments of 278, 124, 81, 54 and $27 \mathrm{bp}$, whereas $P$. vivax-like showed two fragments at positions $708 \mathrm{bp}$ and $126 \mathrm{bp}$. Using the AluI enzyme, fragments of 135, 106, 100, 54, 43 and $27 \mathrm{pb}$ were formed for $P$. vivax variant VK210. Three fragments of 691, 100 and $43 \mathrm{pb}$ were specific for $P$. vivax variant VK247, whereas for $P$. vivax-like were formed fragments of 731, 62 and $41 \mathrm{pb}$. 


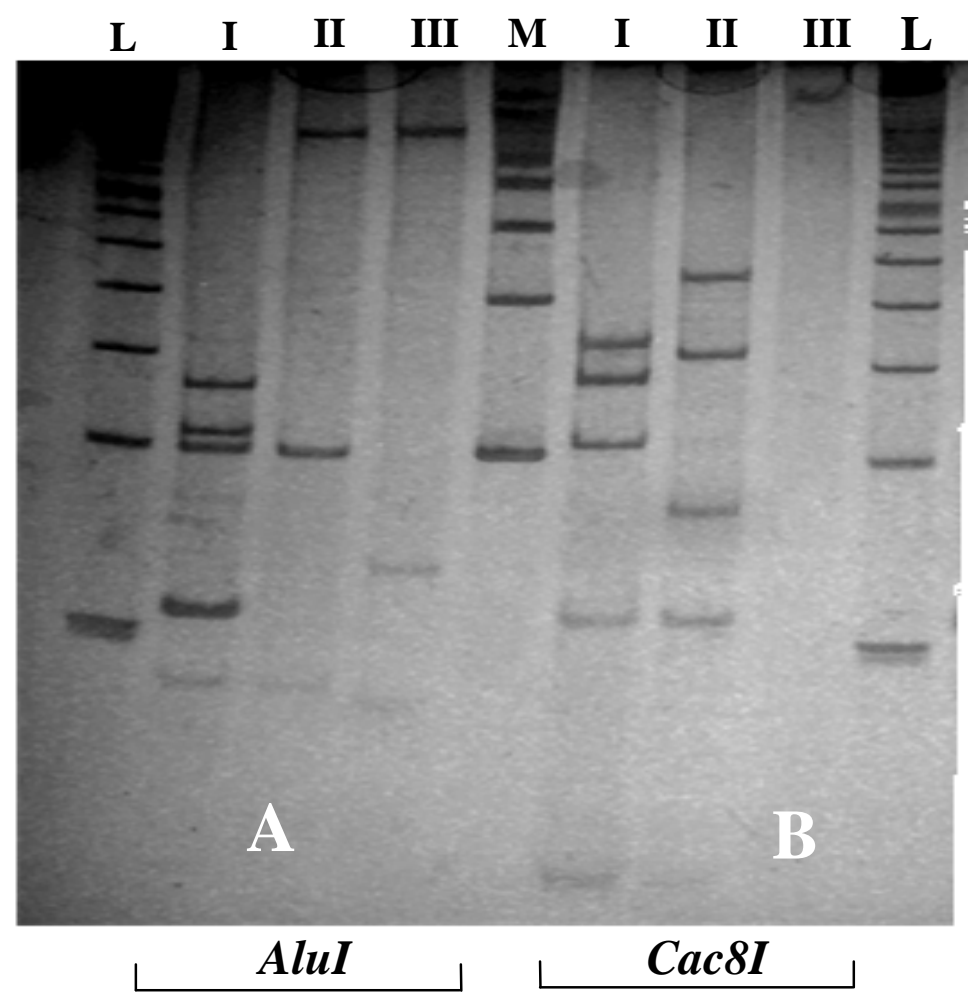

Figure 11. Banding patterns of CS-PCR-RFLP. Digestion of products amplified of $P$. vivax variants VK210, VK247 and $P$. vivax-like. (A) Image showing the fragments of digestion with AluI. (B) The same samples after digestion with Cac8I. L: 50 bp ladder; I: VK210; II: VK247; III: P. vivax-like; M: 100 bp ladder. The products were run on $12.5 \%$ polyacrylamide gel.

\section{Discussion}

The identification of the Plasmodium species in Anopheles mosquitoes is an integral component for the malaria control. The value of this parameter in the understanding of malaria transmission dynamics resides on its accuracy. Traditionally, the detection of a parasite occurs under microscope, but is laborious, demands fresh materials and cannot distinguish between Plasmodium species. The CS-ELISA is widely adopted, however this method show some potential limitations (ROBERT et al., 1988; FONTENILLE et al., 2001; HASAN 
et al., 2009). PCR-based assays are usually more sensitive than other methods (WILSON et al., 1998; PÓVOA et al., 2000; MORENO et al., 2004).

We development a method in which sequences of the $C S$ gene are exploited for use in a PCR which allows the detection and identification of the three variants of $P$. vivax, VK210, VK247 and $P$. vivax-like. Moreover, we used specific conserved sequences for identification of $P$. falciparum and $P$. malariae.

The results of this study showed high concordance between nested PCR described by Snounou et al. (1993b) and newly developed CS-ELISA for detecting $P$. vivax, $P$. falciparum and P.malariae sporozoites in artificially infected mosquitoes $(\kappa=0.723,0.867$ and 0.657 respectively for $P$. vivax, $P$. falciparum and $P$. malariae groups). The lack of agreement between the two assays regarding 11 mosquitoes can be explained by low sporozoite rate in the samples. This may be due to the fact that nested PCR to enhance sensitivity further a nested approach using two rounds of PCR. Moreover, the nested PCR targets small subunit ribosomal RNA, a gene present in four copies per haploid genome, which improves the efficiency of PCR (HASAN et al., 2009). However, the advantage of using the $C S$ gene as target is the ability to identify the $P$. vivax variants.

P. vivax malaria has been endemic in many countries and its CSP genotypes are found worldwide, its effective diagnosis is very important. Indeed, $P$. vivax malaria variants may have different characteristics with respect to the intensity of symptoms and the response to drugs, which could caused failure of control measures (KAIN et al., 1993; MACHADO e PÓVOA, 2000). Besides this, some species of Anopheles have show differential susceptibility to $P$. vivax variants (GONZALES-CERON et al., 1999; GONZALES-CERON et al., 2001; SILVA et al., 2006). Thus, is important to identify $P$. vivax variants in Anopheles mosquitoes to know which anopheline species could be involved in their transmission.

Another reason that motivated the choice of $C S$ gene as target was the fact that its protein is the main target for vaccine development (HERRERA et al. 2007). Consequently, this gene was widely studied and variations in its nucleotide 
sequence are know and deposited in databases. Since the presence of mutations in the primer binding sites can preclude primer-binding during PCR, we investigate multiple $C S$ gene sequences isolated from different regions in the world, available in GenBank database to ensure that there was no change in the binding sequence of newly designed primers (data not shown). In fact, we found only one single base substitution in this region for P. falciparum (Acession: U20969). This is favorable since it allows the method to be played in different endemic areas around the world.

The choice of restriction enzymes was also influenced by our objective of creating an efficient test with optimal resolution of restriction profiles. Based on the sequence analysis of $P$. vivax variants available in GenBank database, the Cac8I endonuclease was found to be the most suitable enzymes for this purpose. However, when it was applied to the products of PCR amplification, it has not produced the expected pattern. Still, it allowed the distinction of all P. vivax variants. AluI enzyme also showed optimal discriminatory power to distinguish all variants.

Despite these advantages, the PCR based methods including this one reported here have some limitations. The requirement for separate PCRs for each species increases time required and assay run cost, and may not suitable for largescale epidemiological surveys. However, PCR-RFLP can serve the purpose when species and $P$. vivax variants detection are required, rather than undertaking the whole process of sequencing. Furthemore, the CS-PCR not identify P. ovale and may be further employed in countries where this species is absent, as in the Brazil.

In conclusions, this comparative study showed a close agreement of the novel CS-PCR with 'gold standard' nested PCR. Moreover, the PCR-RFLP described here demonstrated be highly specific since no samples from other human Plasmodium showed the specific fragment when tested with a given primer pair. Because of its low detection threshold, specially for P. vivax, this assay can be used for the detection even at low parasite levels. Beside this, the CS-PCR-RFLP is the first molecular diagnostic, to our knowledge, that allows the identification of $P$. vivax variants in Anopheles mosquitoes. 


\section{References}

AREZ, A. P.; LOPES, D.; PINTO, J.; FRANCO, A. S.; SNOUNOU, G.; DO ROSÁRIO, V. E. Plasmodium sp.: optimal protocols for PCR detection of low parasite numbers from mosquito (Anopheles sp.) samples. Experimental Parasitology, v. 94, p. 269-272, 2000.

ARNOT, D. E.; BARNWELL, J. W.; TAM, J. P. Circumsporozoite protein of Plasmodium vivax: Gene cloning and characterization of the immunodominant epitope. Science, v. 230, n. 4727, p. 815-817, 1985.

BASS, C.; NIKOU, D.; BLAGBOROUGH, A. M.; VONTAS, J.; SINDEN, R. E.; WILLIAMSON, M. S.; FIELD, L. M. PCR-based detection of Plasmodium in Anopheles mosquitoes: a comparison of a new high-throughput assay with existing methods. Malaria Journal, v. 7, n. 177, 2008.

BRASIL. Ministério da Saúde. Secretaria de Vigilância em Saúde. Sistema de Informações de Vigilância Epidemiológica (SIVEP) - Malária. Resumo epidemiológico de malária no Brasil. 2009. Disponível em:

<http://portalweb04.saude.gov.br/sivep_malaria>. Acesso em 12 fev. 2009.

DAME, J. B.; WILLIAMS, J. L.; McCUCTHAN, T. F. M.; WEBER, J. L.; WIRTZ, R. A.; HOCKMEYER, W. T.; MALOY, W. L.; HAYNES, J. D.; SCHNEIDER, I.; ROBERTS, D. Structure of the gene encoding the immunodominant surface antigen of the human malaria parasite Plasmodium falciparum. Science, v.225, n. 4662, p. 593-599, 1984.

FONTENILLE, D.; MEUNIER, J. Y.; NKONDJIO, C. A.; TCHUINKAM, T. Use of circumsporozoite protein enzyme-linked immunosorbent assay compared with microscopic examination of salivary glands for calculation of malaria infectivity rates in mosquitoes (Diptera: Culicidae) from Cameroon. Journal of Medical Entomology, v. 38, n. 3, p. 451-454, 2001.

GONZALEZ-CERON, L.; RODRIGUEZ, M. H.; NETTEL, J. C.; VILLARREAL, C.; KAIN, K. C.; HERNANDEZ, J. E. Differential susceptibilities of Anopheles albimanus and Anopheles pseudopunctipennis to infections with coindigenous Plasmodium vivax variants VK210 and VK247 in southern Mexico. Infection and Immunity, v. 67, n. 1, p. 410-412, 1999. 
GONZÁLEZ-CERÓN, L.; RODRIGUEZ, M. H.; SANTILLAN, F.; CHAVEZ, B.; NETTLE, J. A.; HERNÁNDEZ-AVILA, J. E.; KAIN, K. C. Plasmodium vivax: Ookinete destruction and oocyst development arrest are responsible for Anopheles albimanus resistance to circumsporozoite phenotype VK247 parasites. Experimental Parasitology, v. 98, n. 3, p. 152-161, 2001.

HASAN, A. U.; SUGURI, S.; SATTABONGKOT, J.; FUJIMOTO, C.; AMAKAWA, M.; HARADA, M.; OHMAE, H. Implementation of a novel PCR based method for detecting malaria parasites from naturally infected mosquitoes in Papua New Guinea. Malaria Journal, v. 8, n. 182, 2009.

HERRERA, S.; CORRADIM, G.; ARÉVALO-HERRERA, M. An update on the search for a Plasmodium vivax vaccine. Trends in Parasitology, v. 23, p. 122127, 2007.

KAIN, K. C.; BROWN, A. E.; LANAR, D. E. Response of Plasmodium vivax variants to chloroquine as determined by microscopy and quantitative Polymerase Chain Reaction. American Journal of Tropical Medicine and Hygiene, v. 49, n. 4, p. 478-484, 1993.

KAMPEN, H. Integration of Anopheles beklemishevi (Diptera: Culicidae) in a PCR assay diagnostic for palaearctic Anopheles maculipennis sibling species. Parasitology research, v. 97, n. 2, p. 113-117, 2005.

LAL, A. A.; de la CRUZ, V. F.; CAMPBELL, G. H.; PROCELL, P. M.; COLLINS, W. E.; McCUTCHAN, T. F. Structure of the circumsporozoite gene of Plasmodium malariae. Molecular and Biochemical Parasitology, v. 30, n. 3, p. 291-294, 1988.

MACHADO, R. L. D.; PÓVOA, M. M. Distribution of Plasmodium vivax variants (VK210, VK247 and P.vivax-like) in three endemic areas of Amazonian Brazil and their correlation with chloroquine-treatment. Transactions of the Royal Society of Tropical Medicine and Hygiene, v. 94, n. 4, p. 377-381, 2000.

MACHADO, R. L.; FIGUEREIDO FILHO, A. F.; CALVOSA, V. S.; FIGUEREDO, M. C.; NASCIMENTO, J. M.; PÓVOA, M. M. Correlation between Plasmodium vivax variants in Belém, Pará State, Brazil and symptoms and clearance of parasitaemia. The Brazilian Journal of Infectious Diseases, v. 7, n. 3, p. 175-177, 2003. 
MORENO, M.; CANO, J.; NZAMBO, S.; BOBUAKASI, L.; BUATICHE, J. N.; ONDO, M.; MICHA, F.; BENITO, A. Malaria Panel Assay versus PCR: detection of naturally infected Anopheles melas in a coastal village of Equatorial Guinea. Malaria Journal, v. 3, n. 6, 2004.

OZAKI, L. S.; SVEC, P.; NUSSENZWEIG, F. T. S.; NUSSENZWEIG, V.; GODSON, G. N. Structure of the Plasmodium knowlesi Gene Coding for the Circumsporozoite Protein. Cell, v. 34, n. 3, p. 815-822, 1983.

PÓVOA, M. M.; MACHADO, R. L.; SEGURA, M. N.; VIANNA, G. M.; VASCONCELOS, A. S.; CONN, J. E. Infectivity of malaria vector mosquitoes: correlation of positivity between ELISA and PCR-ELISA tests. Transactions of the Royal of Tropical Medicine and Hygiene, v. 94, n. 1, p. 106-107, 2000.

ROBERT, V.; VERHAVE, J. P.; PONNUDURAI, T.; LOUWÉ, L.; SCHOLTENS, P.; CARNEVALE, P. Study of the distribution of circumsporozoite antigen in Anopheles gambiae infected with Plasmodium falciparum, using the enzyme-linked immunosorbent assay. Transactions of the Royal Society of Tropical Medicine and Hygiene, v. 82, p. 389-391, 1988.

RYAN, J. R.; DAVE, K.; EMMERICH, E.; GARCIA, L.; YI, L.; COLEMAN, R. E.; SATTABONGKOT, J.; DUNTON, R. F.; CHAN, A. S.; WIRTZ, R. A. Dipsticks for rapid detection of Plasmodium in vectoring Anopheles mosquitoes. Medical and Veterinary Entomology, v. 15, n. 2, p. 225-230, 2001.

SATTABONGKOT, J.; KIATTIBUT, C.; KUMPITAK, C.; PONLAWAT, A.; RYAN, J. R.; CHAN, A. S.; DAVÉ, K.; WIRTZ, R. A.; COLEMAN, R. E. Evaluation of the VecTest Malaria Antigen Panel assay for the detection of Plasmodium falciparum and $P$. vivax circumsporozoite protein in anopheline mosquitoes in Thailand. Journal of Medical Entomology, v. 41, p. 209-214. 2004.

SILVA, A. N.; SANTOS, C. C.; LACERDA, R. N.; MACHADO, R. L.; PÓVOA, M. M. Susceptibility of Anopheles aquasalis and An. darlingi to Plasmodium vivax VK210 and VK247. Memórias do Instituto Oswaldo Cruz, v. 101, n. 5, p. 547-550, 2006.

SNOUNOU, G.; VIRIYAKOSOL, S.; JARRA, W.; THAITHONG, S.; BROWN, $\mathrm{K}$. N. Identification of the four human malaria parasite species in field samples by 
the polymerase chain reaction and detection of a high prevalence of mixed infections. Molecular and Biochemical Parasitology, v. 58, p. 283-92, 1993a.

SNOUNOU, G.; VIRIYAKOSOL, S.; ZHU, X. P.; JARRA, W.; PINHEIRO, L.; DO ROSARIO, V. E.; THAITHONG, S.; BROWN, K. N. High sensitivity of detection of human malaria parasites by the use of nested polymerase chain reaction. Molecular and Biochemical Parasitology, v. 61, n. 2, p. 315-320, $1993 b$.

STORTI-MELO, L. M.; SOUZA-NEIRAS, W. C.; CASSIANO, G. C.; JOAZEIRO, A. C.; FONTES, C. J.; BONINI-DOMINGOS, C. R.; COUTO, A. A.; PÓVOA, M. M.; MATTOS, L. C.; CAVASINI, C. E.; ROSSIT, A. R.; MACHADO, R. L. Plasmodium vivax circumsporozoite variants and Duffy blood group genotypes in the Brazilian Amazon region. Transactions of the Royal Society of Tropical Medicine and Hygiene, v. 103, n. 7, p. 672-678, 2009.

WILSON, M. D.; OFOSU-OKYERE, A.; OKOLI, A. U.; McCALL, P. J.; SNOUNOU, G. Direct comparison of microscopy and polymerase chain reaction for the detection of Plasmodium sporozoites in salivary glands of mosquitoes.

Transactions of the Royal Society of Tropical Medicine and Hygiene, v. 92, n. 5, p. 482-483, 1998.

WIRTZ, R. A.; ZAVALA, F.; CHAROENVIT, Y.; CAMPBELL, G. H.; BURKOT, T. R.; SCHNEIDER, I.; ESSER, K. M.; BEAUDOIN, R. L.; ANDRE, R. G. Comparative testing of monoclonal antibodies against Plasmodium falciparum sporozoites for ELISA development. Bulletin of the World Health Organization, v. 65, n. 1, p. 39-45, 1987. 


\section{Discussão}

O processo de extração de DNA de artrópodes apresenta desafios para fornecer amostras livres de inibidores de PCR (HIGGINS e AZARD, 1995; SIRIDEWA et al., 1996) e a sensibilidade da detecção de parasitos por PCR depende muito do método de extração do DNA da amostra (LARDEUX et al., 2008). Para a realização deste trabalho, selecionamos alguns procedimentos descritos na literatura, e ao realizar dois destes, por fenol-clorofórmio e com o kit Invisorb® Spin Tissue Mini Kit (Invitek, Berlin, Germany), não conseguimos amostras de qualidade para darmos procedimento na PCR, fato este confirmado com as baixas quantidades de DNA determinadas por densidade óptica em espectrofotômetro (NanoDrop® ND-1000 UV-Vis). Para testarmos os protocolos de extração, também realizamos a amplificação do ITS2 e parte da extremidade 3' do gene 5.8S e da extremidade 5' do gene 28S, segundo Kampen (2005). Feito estes procedimentos, o protocolo utilizando o DNAzol (Invitrogen Life Technologies, Carlsbad, EUA) apresentou resultados satisfatórios e foi selecionado no procedimento desenvolvido (Anexo D).

Nós desenvolvemos um método que tem como alvo o gene $C S$ para a realização da PCR. A escolha do gene $C S$ foi motivada por algumas razões. Ele apresenta uma região central repetitiva, que apresenta polimorfismos que determinam as variantes VK210, VK247 e P. vivax-like do P. vivax. Sendo assim, esta é a única forma conhecida de identificá-las. Também, a proteína circunsporozoítica é um dos principais alvos para o desenvolvimento de vacinas. Assim, este gene foi amplamente estudado e variações na sequência de nucleotídeos são conhecidas e depositadas em bancos de dados, possibilitando a comparação de sequências de vários isolados em regiões distintas no mundo.

Os iniciadores foram desenhados com o auxílio do programa Primer3 v 0.4.0 (http://frodo.wi.mit.edu/). Eles foram selecionados a partir das sequências com os seguintes números de acesso: M11926, para a variante VK210; EU401928 para a variante VK247; U09738 para a variante $P$. vivax-like; J03992 para o $P$. 
malariae; K02194 para o P. falciparum. Para a seleção dos iniciadores para as variantes, apenas as regiões não repetitivas foram analisadas, visto o intuito de amplificar a região central do gene (Anexo A). Estas regiões foram deduzidas a partir da sequência de aminoácidos, disponível no GenBank juntamente com a sequência nucleotídica. Para a seleção dos iniciadores do $P$. falciparum e do $P$. malariae, todo o gene foi analisado.

Os iniciadores selecionados foram submetidos à análise pelo software IDT OligoAnalyser 3.1 (Integrated DNA Technologies, Inc., Coralville, IA) (http://www.idtdna.com/analyzer/Applications/OligoAnalyzer/) para predição de suas propriedades termodinâmicas (Anexo A). As propriedades avaliadas foram: temperatura de desnaturação $\left(\mathrm{T}_{\mathrm{M}}\right)$ estabilidade das possíveis interações do iniciador com ele mesmo e com seu(s) respectivo(s) par na reação de PCR. Os melhores iniciadores desenhados foram selecionados com base em parâmetros termodinâmicos utilizados na predição dos iniciadores para a PCR com seus respectivos alvos. Matveeva et al. (2003) correlacionando a eficiência de hibridação de iniciadores com seus alvos com a energia livre de Gibbs (dG) calculada para pareamentos intramoleculares e intermoleculares encontrou valores ótimos quando $\mathrm{dG}>-8 \mathrm{Kcal} / \mathrm{mol}$ para interações intermoleculares e $\mathrm{dG}>-1,1$ $\mathrm{Kcal} / \mathrm{mol}$ para interações intramoleculares. Nenhum dos nossos iniciadores desenhados ultrapassou estes limites.

Após analisarmos o alinhamento das sequências, verificamos que as regiões de anelamento de todos os iniciadores selecionados encontram-se bastante conservadas (Anexo B). Este é um aspecto bastante favorável, pois poderá permitir o emprego desta metodologia na identificação do Plasmodium em áreas endêmicas de diferentes regiões geográficas.

Os resultados deste estudo mostraram que a nova metodologia aqui desenvolvida apresentou alta concordância com o 'gold standard' nested PCR quando empregados em mosquitos infectados artificialmente $(\kappa=0,723,0,867 \mathrm{e}$ 0,657 respectivamente para o $P$. vivax, $P$. falciparum e $P$. malariae. A falta de concordância entre os dois testes em relação a 11 anofelinos pode ser explicada devido as baixas taxas de esporozoítos nas amostras. Assim, isto poderia indicar 
uma maior sensibilidade da nested PCR devido a utilização de duas rodadas de PCR. Além disso, a nested PCR descrita por Snounou et al. (1993) tem como alvo o gene da subunidade menor do RNA ribosomal, com 4 cópias presentes por genoma haplóide, o que aumenta a eficiência da PCR (HASAN et al., 2009). Entretanto, a vantagem de utilizar o gene $C S$ como alvo é a possibilidade de identificar as variantes do $P$. vivax.

As variantes do $P$. vivax podem ter implicações na competência vetorial (GONZALEZ-CERON et al., 1999; SILVA et al., 2006), diferenças na resposta ao tratamento (KAIN et al., 1993; MACHADO et al., 2003) e na intensidade dos sintomas (KAIN et al., 1993). Assim, diagnosticar estas diferentes variantes no vetor pode ter importantes implicações no conhecimento da epidemiologia da malária. Estas são diferenciadas por apresentarem diferentes sequências repetitivas na porção central da CSP (QARI et al., 1994).

Para então evidenciarmos as três variantes, optamos por desenvolver uma metodologia de PCR-RFLP, utilizando enzimas de digestão que produzam fragmentos característicos para cada uma delas. Baseado na análise de sítios de restrição da sequência amplificada verificou-se que a enzima Cac8I formaria um padrão de fragmentos claramente distinguíveis. No entanto, em nossos testes realizados com esta enzima, embora se tenha formado um padrão apropriado para a distinção das variantes, este diferiu daquele anteriormente previsto. Assim, optamos também por testar outra enzima, AluI, que também produziu um padrão de fragmentos apropriado para a distinção das três variantes.

A despeito destas vantagens, a metodologia descrita neste trabalho apresenta algumas limitações. A necessidade de se realizar reações separadas para a identificação das três espécies do Plasmodium acarreta em um maior tempo para a realização do teste bem como aumenta seu custo, podendo não ser recomendado para a realização de grandes investigações epidemiológicas. Entretanto, a CSPCR-RFLP pode ser de grande valor quando a identificação das variantes do $P$. vivax é requerida. 
Conclusões 


\section{Conclusões}

- A CS-PCR desenvolvida foi capaz de identificar as espécies $P$. vivax, $P$. falciparum e P. malariae;

- Por meio da PCR-RFLP, as variantes VK210, VK247 e P. vivax-like puderam ser distinguidas de maneira inequívoca;

- A CS-PCR apresentou alta concordância com o 'gold standard' nested PCR, possuindo boa reprodutibilidade. 
Referências 


\section{REFERÊNCIAS}

ALECRIM, M. G.; ALECRIM, W.; MACEDO, V. Plasmodium vivax resistance to chloroquine (R2) and mefloquine (R3) in Brazilian Amazon region. Revista da Sociedade Brasileira de Medicina Tropical, v. 32, n. 1, p. 67-68, 1999.

APPAWU, M. A.; BOSOMPEM, K. M.; DADZIE, S.; MCKAKPO, U. S.; ANIM-BAIDOO, I.; DYKSTRA, E.; SZUMLAS, D. E.; ROGERS, W. O.; KORAM, K.; FRYAUFF, D. J. Detection of malaria sporozoites by standard ELISA and VecTestTM dipstick assay in field-collected anopheline mosquitoes from a malaria endemic site in Ghana. Tropical Medicine and International Health, v. 8, n. 11, p. 1012-1017, 2003.

ARNOT, D. E.; BARNWELL, J. W.; TAM, J. P. Circumsporozoite protein of Plasmodium vivax: Gene cloning and characterization of the immunodominant epitope. Science, v. 230, n. 4727, p. 815-817, 1985.

ARRUDA, M. E.; ARAGAKI, C.; GAGLIARDI, F.; HALLE, R.W. A seroprevalence and descriptive epidemiological study of malaria among Indian tribes of the Amazon basin of Brazil. Annals of Tropical Medicine and Parasitology, v. 90, n. 2, p. 135-143, 1996.

ARRUDA, M.; CARVALHO, M. B.; NUSSENZWEIG, R. S.; MARACIC, M.; FERREIRA, A. W.; COCHRANE, A. H. Potential vectors of malaria and their different susceptibility to Plasmodium falciparum and Plasmodium vivax in northern Brazil identified by immunoassay. American Journal of Tropical Medicine and Hygiene, v. 35, n. 5, p. 873-881, 1986.

AYALA, F. J.; ESCALANTE, A. A.; RICH, S. M. Evolution of Plasmodium and the recent origin of the world populations of Plasmodium falciparum.

Parasitologia, v. 41, n. 1-3, p. 55-68, 1999.

AYRES, M.; AYRES, M.; J. R.; AYRES, D. L.; DOS SANTOS, A. S. Bioestat: 3.0 aplicações estatísticas nas áreas das ciências biológicas e médicas. Belém: Sociedade Civil Mamirauá MCT - CNPq Conservation International; 2003. 
BANGS, M. J.; RUSMIARTO, S.; GIONAR, Y. R.; CHAN, A. S.; DAVE, K.; RYAN, J. R. Evaluation of a Dipstick Malaria Sporozoite Panel Assay for Detection of Naturally Infected Mosquitoes. Journal of Medical Entomology, v. 39, n. 2, p. 324-330, 2002.

BARCELAR, R. C. Brazil's contribution to tropical medicine and malaria. Proceedings of the Seventh International Congresses on Tropical Medicine and Malaria, Rio de Janeiro, ed. Gráfica Olimpica, 1963.

BASS, C.; NIKOU, D.; BLAGBOROUGH, A. M.; VONTAS, J.; SINDEN, R. E.; WILLIAMSON, M. S.; FIELD, L. M. PCR-based detection of Plasmodium in Anopheles mosquitoes: a comparison of a new high-throughput assay with existing methods. Malaria Journal, v. 7, n. 177, 2008.

BATON, L.A.; RANFORD-CARTWRIGHT, L.C. Spreading the seeds of million-murdering death: metamorphoses of malaria in the mosquito. Trends in Parasitology, v. 21, n. 12, p. 573- 580, 2005.

BEEBE, N. W.; COOPER, R. D. Systematics of malaria vector with particular reference to the Anopheles punctulatus group. International Journal for Parasitology, v. 30, n. 1, p. 1-17, 2000.

BEIER, J. C. Malaria parasite development in mosquitoes. Annual Review of Entomology, v. 43, p. 519-543, 1998.

BEIER, J. C.; KOROS, J. K. Anatomical dissemination of circumsporozoite protein in wild Afrotropical Anopheles affects malaria sporozoite rate determination by ELISA. Medical and Veterinary Entomology, v. 5, n. 1, p. 8185, 1991.

BHARTI, A. R.; CHUQUIYAURI, R.; BROUWER, K. C.; STANCIL, J.; LIN, J.; LLANOS-CUENTAS, A.; VINETZ, J. M. Experimental infection of the neotropical malaria vector Anopheles darlingi by human patient-derived Plasmodium vivax in the Peruvian Amazon. American Journal of Tropical Medicine and Hygiene, v. 75, n. 4, p. 610-616, 2006. 
BHATTACHARYA, M. K.; KUMAR, N. Effect of xanthurenic acid on infectivity of Plasmodium falciparum to Anopheles stephensi. International Journal for Parasitology, v. 31, n. 10, p. 1129-1133, 2001.

BONILLA, J. A.; VALIDUM, L.; CUMMINGS, R.; PALMER, C. J. Genetic diversity of Plasmodium vivax Pvcsp and Pvmsp1 in Guyana, South America. American Journal of Tropical Medicine and Hygiene, v. 75, n. 5, p. 830-835, 2006.

BOWDITCH, B. M.; ALBRIGHT, D. G.; WILLIAMS, J. G. K.; BRAUN, M. J. Use of random amplified polymorphic DNA markers in comparative genomes studies. Methods in Enzymology, v. 224, p. 294-309, 1993.

BRANQUINHO, M. S.; ARAÚJO, M. S.; NATAL, D.; MARRELLI, M. T.; ROCHA, R. M.; TAVEIRA, F. A.; KLOETZEL, J. K. Anopheles oswaldoi a potential malaria vector in Acre, Brazil. Transactions of the Royal Society of Tropical Medicine and Hygiene, v. 90, n. 3, p. 233, 1996.

BRANQUINHO, M. S.; LAGOS, C. B.; ROCHA, R. M.; NATAL, D.; BARATA, J. M.; COCHRANE, A. H.; NARDIN, E.; NUSSENZWEIG, R. S.; KLOETZEL, J. K. Anophelines in the state of Acre, Brazil, infected with Plasmodium falciparum, $P$. vivax, the variant $\mathrm{P}$. vivax VK247 and $P$. malariae. Transactions of the Royal Society of Tropical Medicine and Hygiene, v. 87, n. 4, p. 391-394, 1993.

BRANQUINHO, M. S.; MARRELLI, M. T.; CURADO, I.; NATAL, D.; BARATA, J. M.; TUBAKI, R.; CARRÉRI-BRUNO, G. C.; MENEZES, R. T.; KLOETZEL, J. K. Infection of Anopheles (Kerteszia) cruzii by Plasmodium vivax and Plasmodium vivax variant VK247 in the municipalities of São Vicente and Juquitiba, São Paulo. Revista Panamericana de Salud Pública, v. 2, n. 3, p. 189198, 1997.

BRASIL. Ministério da Saúde. Secretaria de Vigilância em Saúde. Sistema de Informações de Vigilância Epidemiológica (SIVEP) - Malária. Resumo epidemiológico de malária no Brasil. 2009. Disponível em:

<http://portalweb04.saude.gov.br/sivep_malaria>. Acesso em 12 fev. 2009.

BRASIL. Ministério da Saúde. Secretaria de Vigilância em Saúde. Sistema de Informações de Vigilância Epidemiológica (SIVEP) - Malária. Dados 
epidemiológicos de malária, por Estado. Amazônia Legal. 2008. Disponível em: <http://portalweb04.saude.gov.br/sivep_malaria〉. Acesso em 21 out. 2008.

BROCHERO, H. H.; LI, C.; WILKERSON, R. C. A newly recognized species in the Anopheles (Nyssorhynchus) albitarsis complex (Diptera: Culicidae) from Puerto Carreno, Colombia. American Journal of Tropical Medicine and Hygiene, v. 76, n. 6, p. 1113-1117, 2007.

BROCHERO, H.; PAREJA, P. X.; ORTIZ, G.; OLANO, V. A. Breeding places and biting activity of Anopheles species in the municipality of Cimitarra, Santander, Colombia. Biomedica, v. 26, n. 2, p. 269-277, 2006.

CARTER, R.; MENDIS, K. N. Evolutionary and historical aspects of the burden of malaria. Clinical Microbiology Reviews, v. 14, n. 4, p. 564-594, 2002.

CARTER, R.; MENDIS, K. Perspective measuring malaria. American Journal of Tropical Medicine and Hygiene, v. 74, n. 2, p. 187-188, 2006.

CAVASINI, M. T. V.; RIBEIRO, W. L.; KAWAMOTO, F.; FERREIRA, M. U. How prevalent is Plasmodium malariae in Rondônia Western Brazilian Amazon? Revista da Sociedade Brasileira de Medicina tropical, v. 33, n. 5, p. 489-492, 2000 .

CERUTTI-JUNIOR, C. Caracterização epidemiológica da malária autóctone do Espírito Santo. 2007. 228 f. Tese (Doutorado) - Faculdade de Medicina da Universidade de São Paulo, Universidade de São Paulo, São Paulo, 2007.

CONN, J. E. A genetic study of the malaria vector Anopheles nuneztovari from Western Venezuela and Colombia. Journal of the American Mosquito Control Association, v. 6, n. 3, p. 400-405, 1990.

CONN, J. E.; MITCHELL, S. E.; COCKBURN, A. F. Mitochondrial DNA analysis of the neotropical malaria vector Anopheles nuneztovari. Genome, v. 41, p. 313-327, 1998. 
CONN, J. E.; RANGEL-PUERTAS, Y.; SEAWRIGHT, J. A new cytotype of Anopheles nuneztovari from western Venezuela and Colombia. Journal of the American Mosquito Control Association, v. 9, n. 3, p.294-301, 1993.

CONN, J. E.; WILKERSON, R. C.; SEGURA, M. N.; SOUZA, R. T.; SCHLICHTING, C. D.; WIRTZ, R. A.; PÓVOA, M. M. Emergence of a new neotropical malaria vector facilitated by human migration and changes in land use. American Journal of Tropical Medicine and Hygiene, v. 66, n. 1, p. 18-22, 2002.

CONSOLI, R. G. B.; LOURENÇO-DE-OLIVEIRA, R. Principais Mosquitos de Importância Sanitária. Rio de Janeiro: Fiocruz, 1994, 225 p.

COURA, J. R.; SUÁREZ-MUTIS, M.; LADEIA-ANDRADE, S. A new challenge for malaria control in Brazil: asymptomatic Plasmodium infection - A Review. Memórias do Instituto Oswaldo Cruz, v. 101, n. 3, p. 229-237, 2006.

CURADO, I. I.; DUARTE, A. M. R. C.; LAL, A. A. Serological investigation of human Plasmodium vivax-like malaria in several localities in the State of São Paulo, Brazil. Memórias do Instituto Oswaldo Cruz, v. 90, Sup. I, p. 284, 1995.

CURADO, I.; DUARTE, A. M. R. C.; LAL, A. A.; OLIVEIRA, S. G.; KLOETZEL, J. K. Antibodies anti bloodstream and circumsporozoite antigens (Plasmodium vivax and Plasmodium malariae/P. brasilianum) in areas of very low malaria endemicity in Brazil. Memórias do Instituto Oswaldo Cruz, v. 92, n. 2, p. 235-243, 1997.

CURADO, I.; MALAFRONTE, R.S.; DUARTE, A. M. C. Malaria epidemiology in low-endemicity areas of the Atlantic Forest in the Vale do Ribeira, São Paulo, Brazil. Acta Tropica, v. 100, n. 1-2, p. 54-62, 2006.

DAME, J. B.; WILLIAMS, J. L.; McCUCTHAN, T. F. M.; WEBER, J. L.; WIRTZ, R. A.; HOCKMEYER, W. T.; MALOY, W. L.; HAYNES, J. D.; SCHNEIDER, I.; ROBERTS, D. Structure of the gene encoding the immunodominant surface antigen of the human malaria parasite Plasmodium falciparum. Science, v.225, n. 4662, p. 593-599, 1984. 
DEANE, L. M. Malaria vectors in Brazil. Memórias do Instituto Oswaldo Cruz, v. 81, Sup 2, p. 5-14, 1986.

DEANE, L. M. Simian malaria in Brazil. Memórias do Instituto Oswaldo Cruz, v. 87, n. 3, p. 1-20, 1992.

DEANE, L. M.; CAUSEY, O. R.; DEANE, M. P. Notas sobre a distribuição e a biologia dos anofelinos das Regiões Nordestina e Amazônica do Brasil. Revista do Serviço Especial de Saúde Pública, v. 1, n. 4, p. 827-963, 1948.

DEANE, L. M.; DANIEL-RIBEIRO, C.; LOURENÇO-DE-OLIVEIRA, R.; OLIVEIRA-FERREIRA, J.; GUIMARÃES, A. E. Study on the natural history of malaria in areas of the Rondonia State-Brazil and problems related to its control. Revista do Instituto de Medicina Tropical de São Paulo, v. 30, n. 3, p. 153156, 1988.

DEANE, L. M.; NETO, J. A. F.; OKUMURA, M.; FERREIRA, M. O. Malaria parasites of Brazilian monkeys. Revista do Instituto de Medicina Tropical de São Paulo, v. 11, n. 2, p. 71-86, 1969.

DUARTE, A. M.; PORTO, M. A.; CURADO, I.; MALAFRONTE, R. S.; HOFFMANN, E. H.; de OLIVEIRA, S. G.; da SILVA, A. M.; KLOETZEL, J. K.; GOMES, A. C. Widespread occurrence of antibodies against circumsporozoite protein and against blood forms of Plasmodium vivax, $P$. falciparum and $P$. malariae in Brazilian wild monkeys. Journal of Medical Primatology, v. 35, n. 2, p. 87-96, 2006.

ESCALANTE, A. A.; BARRIO, E.; AYALA, F. J. Evolutionary origin of human and primate malarias: Evidence from the circumsporozoite protein gene.

Molecular biology and evolution, v. 12, n. 4, p. 616-626, 1995.

FAJARDO, P.; ALZATE, A. Anopheles nuneztovari como vector de malaria en el Bajo Calima, Buenaventura. Colômbia Médica, v. 18, n. 1, p. 14-18, 1987.

FANDEUR, T.; VOLNEY, B.; PENEAU, C.; de THOISY, B. Monkeys of the rainforest in French Guiana are natural reservoirs for $P$. brasilianum/ P. malariae malaria. Parasitology, v. 120, n. 1, p. 11-21, 2000. 
FANELLO, C.; SANTOLAMAZZA, F.; DELLA TORRE, A. Simultaneous identification of species and molecular forms of the Anopheles gambiae complex by PCR-RFLP. Medical and Veterinary Entomology, v. 16, n. 4, p. 461-464, 2002.

FERREIRA, M. E.; GRATTAPAGLIA, D. Introdução ao uso de marcadores moleculares em análise genética. 2ed. Brasília: EMBRAPA-CENARGEN. 1996.

FLORES-MENDOZA, C.; CUNHA, R. A.; ROCHA, D. S.; LOURENÇO-DEOLIVEIRA, R. Identification of food sources of Anopheles aquasalis (Diptera: Culicidae) by precipitin test in the State of Rio de Janeiro, Brazil. Revista de Saúde Pública, v. 30, n. 2, p. 123-134, 1996.

FONTENILLE, D.; MEUNIER, J. Y.; NKONDJIO, C. A.; TCHUINKAM, T. Use of circumsporozoite protein enzyme-linked immunosorbent assay compared with microscopic examination of salivary glands for calculation of malaria infectivity rates in mosquitoes (Diptera: Culicidae) from Cameroon. Journal of Medical Entomology, v. 38, n. 3, p. 451-454, 2001.

FONTES, C. J. F. Epidemiologia da malaria e fatores associados à infecção assintomática por Plasmodium em uma população de garimpeiros da Amazônia brasileira (Mato Grosso, 1996). 2001. Tese (Doutorado) Departamento de clínica médica da Universidade Federal de Minas Gerais, Universidade Federal de Minas Gerais, Belo Horizonte, MG, 2001.

FORATTINI, O. P. 2002. Culicidologia Médica, vol. 2. São Paulo, Editora da Universidade de São Paulo, 864 p.

GALARDO, A. K.; ARRUDA, M.; D'ALMEIDA, A. A. C.; WIRTZ, R.; LOUNIBOS, L. P.; ZIMMERMAN, R. H. Malaria vector incrimination in three rural riverine villages in the Brazilian Amazon. American Journal of Tropical Medicine and Hygiene, v. 76, n. 3, p. 461-469, 2007.

GALVÃO, A. L. A.; DAMASCENO, R. G.; MARQUEZ, A. P. Algumas observações sobre a biologia dos anofelinos de importância epidemiológica de Belém, Pará. Arquivos de Higiene, v. 12, n. 2, p. 51-111, 1942. 
GARROS, C.; KOEKEMOER, L. L.; KAMAU, L.; AWOLOLA, T. S.; VAN BORTEL, W.; COETZEE, M..; COOSEMANS, M.; MANGUIN, S. Restriction fragment length polymorphism method for the identification of major African and Asian malaria vectors with the Anopheles funestus and An. minimus groups.

American Journal of Tropical Medicine and Hygiene, v. 70, n. 3, p. 260-265, 2004.

GHOSH, A. K.; JACOBS-LORENA, M. Plasmodium sporozoite invasion of the mosquito salivary gland. Current Opinion in Microbiology, v. 12, n. 4, p. 394400, 2009.

GONZALES, J. M.; HURTADO, S.; AREVALO-HERRERA, M.; HERRERA, S. Variants of the Plasmodium vivax circumsporozoite protein (VK210 and VK247) in Colombian isolates. Memórias do Instituto Oswaldo Cruz, v. 96, n. 5, p. 709$712,2001$.

GONZALEZ, J. M.; PETER, K.; ESPOSITO, F.; NEBIE, I.; TIERCY, J. M.; BONELO, A.; AREVALO-HERRERA, VALMORI, M. D.; ROMERO, P.; HERRERA, S.; CORRADIN, G.; LOPEZ, J. A. HLA-A*0201 restricted CD8 Tlymphocyte responses to malaria: identification of new Plasmodium falciparum epitopes by IFN-gamma ELISPOT. Parasite Immunology, v. 22, n. 10, p. 501$514,2000$.

GONZALEZ-CERON, L.; RODRIGUEZ, M. H.; NETTEL, J. C.; VILLARREAL, C.; KAIN, K. C.; HERNANDEZ, J. E. Differential susceptibilities of Anopheles albimanus and Anopheles pseudopunctipennis to infections with coindigenous Plasmodium vivax variants VK210 and VK247 in southern Mexico. Infection and Immunity, v. 67, n. 1, p. 410-412, 1999.

GONZÁLEZ-CERÓN, L.; RODRIGUEZ, M. H.; SANTILLAN, F.; CHAVEZ, B.; NETTLE, J. A.; HERNÁNDEZ-AVILA, J. E.; KAIN, K. C. Plasmodium vivax: Ookinete destruction and oocyst development arrest are responsible for Anopheles albimanus resistance to circumsporozoite phenotype VK247 parasites. Experimental Parasitology, v. 98, n. 3, p. 152-161, 2001.

GUERRA, C. A.; SNOW, R. W.; HAY, S. I. Mapping the global extent of malaria in 2005. Trends Parasitology, v. 22, n. 8, p. 353-358, 2006. 
GULIA, M.; SUNEJA, A.; GAKHAR, S. K. Anti-mosquito hemolymph antibodies on fecundity and on the infectivity of malarial parasite Plasmodium vivax to Anopheles stephensi (Diptera Insecta). Japanese Journal of Infectious Disease, v. 55, n. 3, p. 78-82, 2002.

HARBACH, R. E. The classification of genus Anopheles (Diptera: Culicidae): a working hypothesis of phylogenetic relationships. Bulletin of Entomological Research, v. 94, n. 6, p. 537-553, 2004.

HARBACH, R. E.; RATTANARITHIKUL, R.; HARRISON, B. A. Baimaia, a new subgenus for Anopheles kyondawensis Abraham, a unique crabhole-breeding anopheline in Southeastern Asia. Proceedings of the Entomological Society of Washington, v. 107, n. 4, p. 750-761, 2005.

HASAN, A. U.; SUGURI, S.; SATTABONGKOT, J.; FUJIMOTO, C.; AMAKAWA, M.; HARADA, M.; OHMAE, H. Implementation of a novel PCR based method for detecting malaria parasites from naturally infected mosquitoes in Papua New Guinea. Malaria Journal, v. 8, n. 182, 2009.

HAY, S. I.; GUERRA, C. A.; TATEM, A. J.; NOOR, A. M.; SNOW, R. W. The global distribution and population at risk of malaria: past, present, and future. The Lancet Infectious Diseases, v. 4, n. 6, p. 327-336, 2004.

HAYES, J.; CALDERON, G.; FALCON, R.; ZAMBRANO, V. Newly incriminated anopheline vectors of human malaria parasites in Junin Department, Peru. Journal of the American Mosquito Control Association, v. 3, n. 3, p. 418-422, 1987.

HIGGINS, J. A.; AZARD, A. F. Use of polymerase chain reaction to detect bacteria in Arthropods: a review. Journal of Medical Entomology, v. 32, n. 3, p. 213-222, 1995.

HILLYER, J. F.; BARREAU, C.; VERNICK, K. D. Efficiency of salivary gland invasion by malaria sporozoites is controlled by rapid sporozoite destruction in the mosquito hemocoel. International Journal for Parasitology, v. 37, n. 6, p. 673-681, 2007. 
HUGHES, A. L. Circumsporozoite protein genes of malaria parasites (Plasmodium spp.): evidence for positive selection on immunogenic regions.

Genetics, v. 127, n. 2, p. 345-353, 1991.

I.P.C.C. Climate Change 2007: Impacts, Adaptation and Vulnerability. Contribution of Working Group II to the Fourth Assessment Report of the Intergovernmental Panel on Climate Change, PARRY, M. L.; CANZIANI, O. F.; PALUTIKOF, J. P.; VAN DER LINDEN, P. J.; Hanson, C. E. Eds., Cambridge University Press, Cambridge, UK, 2007, 976 p.

KAIN, K. C.; BROWN, A. E.; LANAR, D. E. Response of Plasmodium vivax variants to chloroquine as determined by microscopy and quantitative Polymerase Chain Reaction. American Journal of Tropical Medicine and Hygiene, v. 49, n. 4, p. 478-484, 1993a.

KAIN, K. C.; BROWN, A. E.; MIRABERLLI, L.; WEBSTER, H. K. Detection of Plasmodium vivax by Polymerase Chain Reaction in a field study. The Journal of Infections Diseases, v. 168, n. 5, p. 1323-1326, 1993 b.

KAIN, K. C.; BROWN, A. E.; WEBSTER, H. K. Circumsporozoite genotyping of global isolates of Plasmodium vivax from dried blood specimens. Journal of Clinical Microbiology, v. 30, n. 7, p. 1863-1866, 1992.

KAIN, K. C.; KEYSTONE, J.; FRANKE, E. D.; LANAR, D. E. Global distribution of a variant of the circumsporozoite gene of Plasmodium vivax. The Journal of Infections Diseases, v. 164, n. 1, p. 208-210, 1991.

KAMPEN, H. Integration of Anopheles beklemishevi (Diptera: Culicidae) in a PCR assay diagnostic for palaearctic Anopheles maculipennis sibling species. Parasitology research, v. 97, n. 2, p. 113-117, 2005.

KAWAMOTO, F.; ALEJO-BLANCO, R.; FLECK, S. L.; SINDEN, R. E. Plasmodium berghei: ionic regulation and the induction of gametogenesis. Experimental Parasitology, v. 72, n. 1, p. 33-42, 1991.

KIM, T.; KIM, Y. J.; SONG, K. J.; SONG, J. W.; CHA, S. H.; KIM, Y. K.; SHIN, Y. K.; SUH, I. B.; LIM, C. S. The molecular characteristics of circumsporozoite 
gene subtypes from Plasmodium vivax isolates in Republic of Korea,

Parasitology Research, v. 88, n. 12, p. 1051-1054, 2002.

KIMBI, H. K.; AWAH, N. W.; NDAMUKONG, K. J.; MBUH, J. V. Malaria infection and its consequences in school children. East African Median Journal, v. 82, n. 2, p. 92-97, 2005.

KISZEWSKI, A.; MELLINGER, A.; SPIELMAN, A.; MALANEY, P.; SACHS, S. E.; SACHS, J. A global index representing the stability of malaria transmission. American Journal of Tropical Medicine and Hygiene, v. 70, n. 5, p. 486-498, 2004.

KLEIN, T. A.; LIMA, J. B.; TADA, M. S. Comparative susceptibility of anopheline mosquitoes to Plasmodium falciparum in Rondonia, Brazil. American Journal of Tropical Medicine and Hygiene, v. 44, n. 6, p. 598-603, 1991a.

KLEIN, T. A.; LIMA, J. B.; TADA, M. S.; MILLER, R. Comparative susceptibility of anopheline mosquitoes in Rondonia, Brazil to infection by Plasmodium vivax. American Journal of Tropical Medicine and Hygiene, v. 45, n. 4, p. 463-470, 1991 b.

KOROCHKINA, S.; BARREAU, C.; PRADEL, G.; JEFFERY, E.; LI, J.; NATARAJAN, R.; SHABANOWITZ, J.; HUNT, D.; FREVERT, U.; VERNICK, K. D. A mosquito-specific protein family includes a candidate receptor for malaria sporozoite invasion of salivary glands. Cellular Microbiology, v. 8, n. 1, p. 163-175, 2006.

LAL, A. A.; de la CRUZ, V. F.; CAMPBELL, G. H.; PROCELL, P. M.; COLLINS, W. E.; McCUTCHAN, T. F. Structure of the circumsporozoite gene of Plasmodium malariae. Molecular and Biochemical Parasitology, v. 30, n. 3, p. 291-294, 1988.

LARDEUX, F.; TEJERINA, R.; ALIAGA, C.; URSIC-BEDOYA, R.; LOWENBERGER, C.; CHAVEZ, T. Optimization of a semi-nested multiplex PCR to identify Plasmodium parasites in wild-caught Anopheles in Bolivia, and its application to field epidemiological studies. Transactions of the Royal Society of Tropical Medicine and Hygiene, v. 102, n. 5, 2008. 
LEHR, M. A.; KILPATRICK, C. W.; WILKERSON, R. C.; CONN, J. E. Cryptic Species in the Anopheles (Nyssorhynchus) albitarsis (Diptera: Culicidae) Complex: Incongruence Between Random Amplified Polymorphic DNAPolymerase Chain Reaction Identification and Analysis of Mitochondrial DNA COI Gene Sequences. Annals of Entomological Society of America, v. 98, n. 6, p. 908-917, 2005.

LENSEN, A. H. W.; BOLMER-VAN, M. V.; VAN GEMERT G.J.; ELING, W. M. C.; SAUERWEIN, R. W. Leukocytes in a Plasmodium falciparum-Infected Blood Meal Reduce Transmission of Malaria to Anopheles Mosquitoes. Infection and Immunity, v. 65, n. 9, p. 3834-3837, 1997.

LEVINE, D. The protozoan phylum Apicomplexa. 2. ed. Boca Raton: CRC, 1988. $357 \mathrm{p}$.

LI, F.; NIU, C.; YE, B. Nested polymerase chain reaction in detection of Plasmodium vivax sporozoites in mosquitoes. Chinese Medical Journal (English), v. 114, n. 6, p. 654-657, 2001.

LIM, C. S.; KIM, Y. K.; LEE, K. N.; KIM, S. H.; HOFFMAN, K. J.; SONG, K-J.; SONG, J. H. The analysis of circumsporozoite-protein gene sequences from South Korean isolates of Plasmodium vivax. Annals of Tropical Medicine and Parasitology, v. 95, n. 3, p. 229-235, 2001.

LOCKYER, M. J.; MARSH, K.; NEWBOLD, C. I. Wild isolates of Plasmodium falciparum show extensive polymorphism in T cell epitopes of the circumsporozoite protein. Molecular and Biochemical Parasitology, v. 37, n. 2, p.275-280, 1989.

LOIOLA, C. C. P.; da SILVA, C. J. M.; TAUIL, P. L. Controle da malária no Brasil: 1965 a 2001. Revista Panamerica de Salud Pública, v. 11, n. 4, p. 235244, 2002.

LORENZETTI, A.; FORNAZARI, P. A.; BONINI-DOMINGOS, A. C.; PENHALBEL, R. S. R.; FUGIKAHA, E.; BONINI-DOMINGOS, C. R.; FRAGA, V. D.; CONCEIÇÃO, L. M.; ROSSIT, A. R. B.; CAVASINI, C. E.; COUTO, V. S.; MACHADO, R. L. Mixed Plasmodium falciparum infections and its clinical implications in four areas of the Brazilian Amazon region. Acta Tropica, v. 107, n. 1, p. 8-12, 2008. 
LOURENÇO-DE-OLIVEIRA, R. L.; HEYDEN, R. Alguns aspectos da ecologia dos mosquitos (Diptera: Culicidae) de uma área de planície (Granjas Calábria), em Jacarepaguá, Rio de Janeiro. IV. Preferências alimentares quanto ao hospedeiro e freqüência domiciliar. Memórias do Instituto Oswaldo Cruz, v. 81, n. 1, p. 15-27, 1986.

MACHADO, R. L. D.; PÓVOA, M. M. Distribution of Plasmodium vivax variants (VK210, VK247 and P.vivax-like) in three endemic areas of Amazonian Brazil and their correlation with chloroquine-treatment. Transactions of the Royal Society of Tropical Medicine and Hygiene, v. 94, n. 4, p. 377-381, 2000.

MACHADO, R. L.; D' ALMEIDA, A. A. C.; CAVASINI, C. E.; CALVOSA, V. S. Malaria outside the Brazilian Amazonian region: the situation in Santa Catarina State. Revista do Instituto de Medicina Tropical de São Paulo, v. 36, n. 5, p. 581-586, 2003a.

MACHADO, R. L.; FIGUEREIDO FILHO, A. F.; CALVOSA, V. S.; FIGUEREDO, M. C.; NASCIMENTO, J. M.; PÓVOA, M. M. Correlation between Plasmodium vivax variants in Belém, Pará State, Brazil and symptoms and clearance of parasitaemia. The Brazilian Journal of Infectious Diseases, v. 7, n. 3, p. 175-177, 2003b.

MANN, V. H.; GOOD, M. F.; SAUL, A. Diversity in the circumsporozoite protein of Plasmodium vivax: does it matter? Parasitology Today, v. 11, n. 1, p. 33-36, 1995.

MARRELLI, M. T.; BRANQUINHO, M. S.; HOFFMANN, E. H.; TAIPELAGOS, C. B.; NATAL, D.; KLOETZEL, J. K. Correlation between positive serology for Plasmodium vivax-like/Plasmodium simiovale malaria parasites in the human and anopheline populations in the State of Acre, Brazil. Transactions of the Royal Society of Tropical Medicine and Hygiene, v. 92, n. 2, p. 149-151, 1998.

MARRELLI, M. T.; HONÓRIO, N. A.; FLORES-MENDOZA, C.; LOURENÇODE-OLIVEIRA, R.; MARINOTTI, O.; KLOETZEL, J. K. Comparative susceptibility of two members of the Anopheles oswaldoi complex, An. oswaldoi and An. konderi, to infection by Plasmodium vivax. Transactions of the Royal Society of Tropical Medicine and Hygiene, v. 93, n. 4, p. 381-384, 1999. 
MATVEEVA, O. V.; MATHEWS, D. H.; TSODIKOV, A. D.; SHABALINA, S. A.; GESTELAND, R. F.; ATKINS, J. F.; FREIER, S. M. Thermodynamic criteria for high hit rate antisense oligonucleotide design. Nucleic Acids Research, v. 31, n. 17, p. 4989-4994, 2003.

McCUTCHAN, T. F. Is a monkey malaria from Borneo an emerging human disease? Future Microbiology, v. 3, n. 2, p. 115-118, 2008.

MÉNARD, R.; SULTAN, A. A.; CORTES, C.; ALTSZULER, R.; VAN DIJK, M. R.; JANSE, C. J.; WATERS, A. P.; NUSSENZWEIG, R. S.;

NUSSENZWEIG, V. Circumsporozoite protein is required for development of malaria sporozoites in mosquitoes. Nature, v. 385, n. 6614, p. 336-340, 1997.

MICHEL, K.; KAFATOS, F. C. Mosquito immunity against Plasmodium. Insect Biochemistry and Molecular Biology, v. 35, n. 7, p. 677-689, 2005.

MILLER, L. H.; MASON, S. J.; CLYDE, D. F.; McGINNIS, M. H. The resistance factor to Plasmodium vivax in blacks: Duffy blood group genotype, FyFy. The New England Journal of Medicine, v. 295, n. 6, p. 302-304, 1976.

MIRABELLO, L.; CONN, J. E. Population analysis using the nuclear white gene detects Pliocene/Pleistocene lineage divergence within Anopheles nuneztovari in South America. Medical and Veterinary Entomology, v. 22, n. 2, p. 109-119, 2008.

MORENO, M.; CANO, J.; NZAMBO, S.; BOBUAKASI, L.; BUATICHE, J. N.; ONDO, M.; MICHA, F.; BENITO, A. Malaria Panel Assay versus PCR: detection of naturally infected Anopheles melas in a coastal village of Equatorial Guinea. Malaria Journal, v. 3, n. 6, 2004.

MULLIS, K. B.; FALOONA, F. A. Specific synthesis of DNA in vitro via a Polymerase-catalyzed chain reaction. Methods in Enzymology, v. 155, p. 335$350,1987$.

NEED, J. T.; WIRTZ, R. A.; FRANKE, E. D.; FERNANDEZ, R.; CARBAJAL, F.; FALCON, R.; SAN ROMAN, E. Plasmodium vivax VK247 and VK210 circumsporozoite proteins in Anopheles mosquitoes from Andoas, Peru. Journal of Medical Entomology, v. 30, n. 3, p. 597-600, 1993. 
OLIVEIRA-FERREIRA, J.; NAKAIE, C. R.; DANIEL-RIBEIRO, C. Low frequency of anti-Plasmodium falciparum circumsporozoite repeat antibodies and rate of high malaria transmission in endemic areas of Rondonia State in northwestern Brazil. American Journal of Tropical Medicine and Hygiene, v. 46, n. 6, p. 720-726, 1992.

OLIVEIRA-FERREIRA, J.; PRATT-RICCIO, L. R.; ARRUDA, M.; SANTOS, F.; RIBEIRO, C. T.; GOLDBERG, A. C.; BANIC, D. M. HLA class II and antibody responses to circumsporozoite protein repeats of $P$. vivax (VK210, VK247 and $P$. vivax-like) in individuals naturally exposed to malaria Acta Tropica, v. 92, n. 1, p. 63-69, 2004.

OYEDEJI, S. I.; AWOBODE, H. O.; MONDAY, G. C.; KENDJO, E.; KREMSNER, P. G.; KUN, J. F. Comparison of PCR-based detection of Plasmodium falciparum infections based on single and multicopy genes. Malaria Journal, v. 6, n. 112, 2007.

OZAKI, L. S.; SVEC, P.; NUSSENZWEIG, F. T. S.; NUSSENZWEIG, V.; GODSON, G. N. Structure of the Plasmodium knowlesi Gene Coding for the Circumsporozoite Protein. Cell, v. 34, n. 3, p. 815-822, 1983.

PAGES, F.; ORLANDI-PRADINES, E.; CORBEL, V. Vectors of malaria: biology, diversity, prevention, and individual protection. Medicine et maladies infectieuses, v. 37, n. 3, p. 153-161, 2007.

PATZ, J. A.; OLSEN, S. H. Malaria risk and temperature: Influences from global climate change and local land use practices. Proceedings of the National Academy of Sciences, v. 103, n. 15, p. 5635-5636, 2006.

PÓVOA, M. M.; MACHADO, R. L.; SEGURA, M. N.; VIANNA, G. M.; VASCONCELOS, A. S.; CONN, J. E. Infectivity of malaria vector mosquitoes: correlation of positivity between ELISA and PCR-ELISA tests. Transactions of the Royal of Tropical Medicine and Hygiene, v. 94, n. 1, p. 106-107, 2000.

PÓVOA, M. M.; SOUZA, R. T.; LACERDA, R. N.; ROSA, E. S.; GALIZA, D.; SOUZA, J. R.; WIRTZ, R. A.; SCHLICHTING, C. D.; CONN, J. E. The importance of Anopheles albitarsis $\mathrm{E}$ and An. darlingi in human malaria transmission in Boa Vista, state of Roraima, Brazil. Memórias do Instituto Oswaldo Cruz, v. 101, n. 2, p. 163-168, 2006. 
PÓVOA, M.; WIRTZ, R.; LACERDA, R.; MILES, M.; WARHURST, D. Malaria vectors in the municipality of Serra do Navio, State of Amapá, Amazon Region, Brazil. Memórias do Instituto Oswaldo Cruz, v. 96, n. 2, p. 179-184, 2001.

QARI, S. H.; COLLINS, W. E,; LOBEL, H. O.; TAYLOR, F.; LAL, A. A. A study of polymorphism in the circumsporozoite protein of human malaria parasites. American Journal of Tropical Medicine and Hygiene, v. 50, n. 1, p. 45-51, 1994.

QARI, S. H.; SHI, Y. P.; GOLDMAN, I. F. Identification of Plasmodium vivaxlike human malaria parasite. The Lancet, v. 341, n. 8848, p. 780-783, 1993 a.

QARI, S. H.; SHI, Y. P.; PÓVOA, M. M. Global occurrence of Plasmodium vivax-like human malaria parasite. The Journal of Infectious Diseases, v. 168, n. 6, p. 1485-1489, 1993 b.

RATHORE, D.; SACCI, J. B.; de La VEGA, P.; McCUTCHAN, T. F. Binding and invasion of liver cells by Plasmodium falciparum sporozoites. Essential involvement of the amino terminus of circumsporozoite protein. The Journal of Biological Chemistry, v. 277, n. 9, p. 7092-7098, 2002.

REBELO, J. M.; MORAES, J. L.; ALVES, G. A.; LEONARDO, F. S.; ROCHA, R. V.; MENDES, W. A.; COSTA, E.; CÂMARA, L. E.; SILVA, M. J.; PEREIRA, Y. N.; MENDONÇA, J. A. Distribution of species from genus Anopheles (Diptera, Culicidae) in the State of Maranhão, Brazil. Cadernos de Saúde Pública, v. 23, n. 12, p. 2959-2971, 2007.

RODRIGUEZ, M. H.; GONZALEZ-CERON, L.; HERNANDEZ, J. E. Different prevalence of Plasmodium vivax phenotypes VK210 e VK247 associated with the distribution of Anopheles albimanus and Anopheles pseudopunctipenis in Mexico. American Journal of Tropical Medicine and Hygiene, v. 62, n. 1, p. 122-127, 2000 .

ROSA-FREITAS, M. G.; TSOURIS, P.; PETERSON, A. T.; HONÓRIO, N. A.; BARROS, F. S. M.; AGUIAR, D. B.; GURGEL, H. C.; ARRUDA, M. E.; VASCONCELOS, S. D.; LUITGARDS-MOURA, J. F. An ecoregional classification for the state of Roraima, Brazil: the importance of landscape in malaria biology. Memórias do Instituto Oswaldo Cruz, v. 102, n. 3, p. 349-358, 2007. 
ROSENBERG, R. Inability of Plasmodium knowlesi sporozoites to invade Anopheles freeborni salivary glands. American Journal of Tropical Medicine and Hygiene, v. 34, n. 4, p. 687-691, 1985.

ROSENBERG, R. Plasmodium vivax in Africa: hidden in plain sight? Trends Parasitology, v. 23, n. 7, p. 193-196, 2007.

ROSENBERG, R.; WIRTZ, R. A.; LANAR, D. E. Circumsporozoite protein heterogeneity in the human malaria parasite Plasmodium vivax. Science, v. 245, n. 4921, p. 973-976, 1989.

RUBIO-PALIS, Y.; CURTIS, C. F.; GONZÁLES, C.; WIRTZ, R. A. Host choice of anopheline mosquitoes in a malaria endemic area of western Venezuela.

Medical and Veterinary Entomology, v. 8, n. 3, p. 275-280, 1994.

RUBIO-PALIS, Y.; WIRTZ, R. A.; CURTIS, C. F. Malaria entomological inoculation rates in western Venezuela. Acta Tropica, v. 52, n. 2-3, p. 167-174, 1992.

RYAN, J. R.; DAVE, K.; EMMERICH, E.; GARCIA, L.; YI, L.; COLEMAN, R. E.; SATTABONGKOT, J.; DUNTON, R. F.; CHAN, A. S.; WIRTZ, R. A. Dipsticks for rapid detection of Plasmodium in vectoring Anopheles mosquitoes. Medical and Veterinary Entomology, v. 15, n. 2, p. 225-230, 2001.

SABROZA, P. C. Malária no Brasil. Cadernos de Saúde Pública, v. 1, n. 1, p. 95-99, 1985.

SAIKI, R. K.; GELFAND, D. H.; STOFFEL, S.; SCHARF, S. J.; HIGUCHI, R.; HORN, G. L.; MULLIS, K. B.; ERLICH, H. A. Primer-directed enzymatic amplification of DNA with a thermoestable DNA polymerase. Science, v. 239, n. 4839, p. 487-491, 1988.

SALLUM, M. A.; WILKERSON, R. C.; FORATTINI, O. P. Taxonomic study of species formerly identified as Anopheles mediopunctatus and resurrection of An. costai (Diptera: Culicidae). Journal of Medical Entomology, v. 36, n. 3, p. 282300, 1999. 
SCARPASSA, V. M.; CONN, J. E. Molecular differentiation in natural populations of Anopheles oswaldoi sensu lato (Diptera: Culicidae) from the Brazilian Amazon, using sequences of the COI gene from mitochondrial DNA. Genetics and Molecular Research, v. 5, n. 3, p. 493-502, 2006.

SCARPASSA, V. M.; GEURGAS, S.; AZEREDO-ESPIN, A. M. L.; TADEI, W. P. Genetic divergence in mitochondrial DNA of Anopheles nuneztovari (Diptera: Culicidae) from Brazil and Colombia. Genetic and molecular biology, v. 23, n. 1, p. 71-78, 2000.

SCARPASSA, V. M.; TADEI, W. P.; SUREZ, M. F. Population structure and genetic divergence in Anopheles nuneztovari (Diptera: Culicidae) from Brazil and Colombia. American Journal of Tropical Medicine and Hygiene, v. 60, n. 6, p. 1010-1018, 1999.

SCOPEL, K. K.; FONTES, C. J.; NUNES, A. C.; HORTA, M. F.; BRAGA, E. M. High prevalence of Plamodium malariae infections in a Brazilian Amazon endemic area (Apiacás-Mato Grosso State) as detected by polymerase chain reaction. Acta Tropica, v. 90, n. 1, p. 61-64, 2004.

SIDEN-KIAMOS, I.; LOUIS, C. Interactions between malaria parasites and their mosquito hosts in the midgut. Insect Biochemistry and Molecular Biology, v. 34, n. 7, p. 679-685, 2004.

SILVA, A. N.; SANTOS, C. C.; LACERDA, R. N.; MACHADO, R. L.; PÓVOA, M. M. Susceptibility of Anopheles aquasalis and An. darlingi to Plasmodium vivax VK210 and VK247. Memórias do Instituto Oswaldo Cruz, v. 101, n. 5, p. 547-550, 2006.

SILVA-DO-NASCIMENTO, T. F.; WILKERSON, R. C.; LOURENÇO-DEOLIVEIRA, R.; MONTEIRO, F. A. Molecular confirmation of the specific status of Anopheles halophylus (Diptera: Culicidae) and evidence of a new cryptic species within an. triannulatus in central Brazil. Journal of Medical Entomology, v. 43, n. 3, p. 455-459, 2006.

SILVA-VASCONCELOS, A.; KATÓ, M. Y.; MOURÃO, E. N.; SOUZA, R. T.; LACERDA, R. N.; SIBAJEV, A.; TSOURIS, P.; PÓVOA, M. M.; MOMEN, H.; ROSA-FREITAS, M. G. Biting indices, host-seeking activity and natural 
infection rates of anopheline species in Boa Vista, Roraima, Brazil from 1996 to 1998. Memórias do Instituto Oswaldo Cruz, v. 97, n. 2, p. 151-161, 2002.

SINDEN, R. E. Molecular interactions between Plasmodium and its insect vectors. Cellular Microbiology, v. 4, n. 11, p. 713-724, 2002.

SINDEN, R. E. The cell biology of sexual development in Plasmodium. Parasitology, v. 86, n. 4, p. 7-28, 1983.

SINNIS, P.; COPPI, A. A long and winding road: The Plasmodium sporozoite's journey in the mammalian host. Parasitology International, v. 56, n. 3, p. 171178, 2007.

SIRIDEWA, K.; KARUNANAYAKE, E. H.; CHANDRASEKHARAN, N. V. Polymerase chain reaction-based technique for the detection of Wuchereria bancrofti in human blood samples hydrocele fluid, and mosquito vector.

American Journal of Tropical Medicine and Hygiene, v. 54, n. 1, p. 72-76, 1996.

SNOUNOU, G.; VIRIYAKOSOL, S.; ZHU, X. P.; JARRA, W.; PINHEIRO, L.; DO ROSARIO, V. E.; THAITHONG, S.; BROWN, K. N. High sensitivity of detection of human malaria parasites by the use of nested polymerase chain reaction. Molecular and Biochemical Parasitology, v. 61, n. 2, p. 315-320, 1993.

SNOW, R. W.; GUERRA, C. A.; NOOR, A. M.; MYINT, H. Y.; HAY, S.I. The global distribution of clinical episodes of Plasmodium falciparum malaria.

Nature, v. 434, n. 7030, p. 214-217, 2005.

SOULAMA, I.; NÉBIÉ, I.; OUÉDRAOGO, A.; GANSANE, A.; DIARRA, A.; TIONO, A. B.; BOUGOUMA, E. C.; KONATÉ, A. T.; KABRÉ, G. B.;

TAYLOR, W. R.; SIRIMA, S. B. Plasmodium falciparum genotypes diversity in symptomatic malaria of children living in an urban and a rural setting in Burkina Faso. Malaria Journal, v. 8, n. 135, 2009.

STORTI-MELO, L. M.; SOUZA-NEIRAS, W. C.; CASSIANO, G. C.; JOAZEIRO, A. C.; FONTES, C. J.; BONINI-DOMINGOS, C. R.; COUTO, A. A.; PÓVOA, M. M.; MATTOS, L. C.; CAVASINI, C. E.; ROSSIT, A. R.; 
MACHADO, R. L. Plasmodium vivax circumsporozoite variants and Duffy blood group genotypes in the Brazilian Amazon region. Transactions of the Royal Society of Tropical Medicine and Hygiene, v. 103, n. 7, p. 672-678, 2009.

TADEI, W. P.; dos SANTOS, J. M.; COSTA, W. L.; SCARPASSA, V. M. Biology of Amazonian Anopheles. XII. Occurrence of Anopheles species, transmission dynamics and malaria control in the urban area of Ariquemes (Rondônia). Revista do Instituto de Medicina Tropical de São Paulo, v. 30, n. 3, p. 221-251, 1988.

TADEI, W. P.; DUTARY-THATCHER, B. Malaria vectors in the Brazilian amazon: Anopheles of the subgenus Nyssorhynchus. Revista do Instituto de Medicina Tropical de São Paulo, v. 42, n. 2, p. 87-94, 2000.

TADEI, W. P.; THATCHER, B. D.; SANTOS, J. M.; SCARPASSA, V. M.; RODRIGUES, I. B.; RAFAEL, M. S. Ecologic observations on anopheline vectors of malaria in the Brazilian Amazon. American Journal of Tropical Medicine and Hygiene, v. 59, n. 2, p. 325-335, 1998.

TAHAR, R.; RINGWALD, P.; BASCO, L. K. Heterogeneity in the circumsporozoite protein gene of Plasmodium malariae isolates from sub-Saharan Africa. Molecular and Biochemical Parasitology, v. 92, n. 1, p. 71-78, 1998.

TAUIL, P. L.; DANIEL-RIBEIRO, C. T. Some aspects of epidemiology and control of malaria in Brazil. Research and Reviews in Parasitology, v. 58, n. 34, p. 163-167, 1998.

VAN BORTEL, W.; SOCHANTA, T.; HARBACH, R. E.; SOCHEAT, S.; ROELANTS, P.; BACKELJAU, T.; COOSEMANS, M. Presence of Anopheles culifascies B in Cambodia established by the PCR-RFLP assay developed for the identification of Anopheles minimus species $\mathrm{A}$ and $\mathrm{C}$ and four related species. Medical and Veterinary Entomology, v. 16, n. 3, p. 329-334, 2002.

VAN BORTEL, W.; TRUNG, H. D.; ROELANTS, P.; HARBACH, R. E.; BACKELJAU, T.; COOSEMANS, M. Molecular identification of Anopheles minimus s.l. beyond distinguishing the members of the species complex. Insect Molecular Biology, v. 9, n. 3, p. 335-340, 2000. 
VOLNEY, B.; POULIQUEN, J. F.; de THOISY, B.; FANDEUR, T. A seroepidemiological study of malaria in human and monkey populations in French Guiana. Acta Tropica, v. 82, n. 1, p. 11-23, 2002.

WILKERSON, R. C.; GAFFIGAN, T. V.; BENTO LIMA J. Identification of species related to Anopheles (Nyssorhynchus) albitarsis by random amplified polymorphic DNA-polymerase chain reaction (Diptera: Culicidae). Memórias do Instituto Oswaldo Cruz, v. 90, n. 6, p. 721-732, 1995 b.

WILKERSON, R. C.; PARSONS, T. J.; KLEIN, T. A.; GAFFIGAN, T. V.; BERGO, E.; CONSOLIM, J. Diagnosis by random amplified polymorphic DNA polymerase chain reaction of four cryptic species related to Anopheles (Nyssorhynchus) albitarsis (Diptera: Culicidae) from Paraguay, Argentina, and Brazil. Journal of Medical Entomology, v. 32, n. 5, p. 697-704, 1995a.

WILSON, M. D.; OFOSU-OKYERE, A.; OKOLI, A. U.; McCALL, P. J.;

SNOUNOU, G. Direct comparison of microscopy and polymerase chain reaction for the detection of Plasmodium sporozoites in salivary glands of mosquitoes.

Transactions of the Royal Society of Tropical Medicine and Hygiene, v. 92, n. 5, p. 482-483, 1998.

WIRTZ, R. A.; ROSENBERG, R.; SATTABONGKOT, J.; WEBSTER, H. K. Prevalence of antibody to heterologous circumsporozoite protein of Plasmodium vivax in Thailand. The Lancet, v. 336, n. 8715, p. 593-595, 1990.

WIRTZ, R. A.; SATTABONGKOT, J.; HALL, T.; BURKOT, T. R.; ROSENBERG, R. Development and evaluation of an enzyme-linked immunosorbent assay for Plasmodium vivax-VK247 sporozoites. Journal of Medical Entomology, v. 29, n. 5, p. 854-857, 1992.

WIRTZ, R. A.; ZAVALA, F.; CHAROENVIT, Y.; CAMPBELL, G. H.; BURKOT, T. R.; SCHNEIDER, I.; ESSER, K. M.; BEAUDOIN, R. L.; ANDRE, R. G. Comparative testing of monoclonal antibodies against Plasmodium falciparum sporozoites for ELISA development. Bulletin of the World Health Organization, v. 65, n. 1, p. 39-45, 1987.

WORLD HEALTH ORGANIZATION (WHO). Rolling back malaria. The world health report 1999: making a difference. Geneva: World Health Organization, 1999. 
WORLD HEALTH ORGANIZATION (WHO). WHO expert committee on malaria: twentieth report. Geneva: World Health Organization, 2000.

WORLD HEALTH ORGANIZATION (WHO). World malaria report 2008. Geneva (Switzerland): World Health Organization; 2008.

ZAVALA, F.; COCHRANE, A. H.; NARDIN, E. H.; NUSSENZWEIG, R. S.; NUSSENZWEIG, V. Circumsporozoite proteins of malaria parasites contain a single immunodominant region with two or more identical epitopes. The Journal of Experimental Medicine, v. 157, n. 6, p. 1947-1957, 1983. 
Anexos 
ANEXO A

\section{Desenho e característica dos oligonucleotídeos iniciadores}

\begin{tabular}{|c|c|c|c|c|}
\hline Iniciador & $\begin{array}{c}\text { Sequência } \\
5^{\prime}-3^{\prime}\end{array}$ & Posição & Espécie & $\begin{array}{l}\text { Tamanho do } \\
\text { fragmento de } \\
\text { PCR (pb) }\end{array}$ \\
\hline PVCSP1 & AGGCAGAGGACTTGGTGAGA & 174-193 & \multirow{3}{*}{ P. vivax } & 789 (VK210) \\
\hline & & & & 834 (VK247) \\
\hline PVCSP2 & CCACAGGTTACACTGCATGG & $943-962$ & & 834 (P. vivax-like) \\
\hline PFCSP1 & CCAGTGCTATGGAAGTTCGTC & $69-89$ & \multirow[t]{2}{*}{ P. falciparum } & \multirow[t]{2}{*}{118} \\
\hline PFCSP2 & CCAATTTTCCTGTTTCCCATAA & $245-266$ & & \\
\hline PMCSP1 & ATATAGACTTGCTCCAACATGAAGAA & $-18-08$ & \multirow[t]{2}{*}{ P. malariae } & \multirow[t]{2}{*}{199} \\
\hline PMCSP2 & AATGATCTTGATTCGTGCTATATCTG & $156-181$ & & \\
\hline
\end{tabular}

Quadro 1 - Iniciadores selecionados para a amplificação do gene $C S$ das espécies $P$. vivax, $P$. falciparum e $P$. malariae. A posição e o tamanho do fragmento esperado são determinados a partir das sequências com os seguintes números de acesso: M11926, para a variante VK210; EU401928 para a variante VK247; U09738 para a variante $P$. vivax-like; J03992 para o P. malariae; K02194 para o P. falciparum.

\begin{tabular}{|c|c|c|c|c|c|c|c|}
\hline Iniciador & $\begin{array}{c}\text { Tamanho } \\
\text { (pb) }\end{array}$ & $\begin{array}{c}\% \mathbf{G} \\
\mathrm{C}\end{array}$ & $\begin{array}{l}\mathrm{T}_{\mathrm{M}} \\
\left({ }^{\circ} \mathrm{C}\right)\end{array}$ & $\begin{array}{c}\text { Hairpin } \\
\text { Kcal/mol }\end{array}$ & $\begin{array}{c}\text { Self-dimer } \\
\text { Kcal/mol }\end{array}$ & $\begin{array}{c}\text { Hetero-dimer } \\
\text { Kcal/mol }\end{array}$ & $\begin{array}{l}\Delta \mathbf{T}_{\mathrm{M}} \\
\left({ }^{\circ} \mathrm{C}\right)\end{array}$ \\
\hline PVCSP1 & 20 & 55,0 & 59,9 & 1,58 & $-3,14$ & \multirow{2}{*}{$-6,69$} & \multirow{2}{*}{0,1} \\
\hline PVCSP2 & 20 & 55,0 & 60,0 & 1,92 & $-7,05$ & & \\
\hline PFCSP1 & 21 & 52,3 & 59,7 & 1,48 & $-5,02$ & \multirow{2}{*}{$-7,46$} & \multirow{2}{*}{0,3} \\
\hline PFCSP2 & 22 & 36,3 & 60,0 & 2,34 & $-5,36$ & & \\
\hline PMCSP1 & 26 & 34,6 & 59,6 & 1,90 & $-5,38$ & \multirow{2}{*}{$-6,47$} & \multirow{2}{*}{0,3} \\
\hline PMCSP2 & 26 & 34,6 & 59,9 & 1,31 & $-4,62$ & & \\
\hline
\end{tabular}

Quadro 2 - Predição in silico dos iniciadores pelo software IDT OligoAnalyser 3.1.Tamanho dos iniciadores, Porcentagem GC, temperatura de desnaturação, da diferença entre as temperaturas de desnaturação de cada par de iniciadores e das energias livres de formação de hairpins, interação self-dimer e interações hetero-dimer. 


\subsection{Oligonucleotídeos PVCSP1 e PVCSP2.}

Regiões não repetitivas 5'e 3'

Região repetitiva

Sequência dos iniciadores

P. vivax (VK210) - M11926

ATGAAGAACTTCATTCTCTTGGCTGTTTCTTCCATCCTGTTGGTGGACTTGTTCCCCACGCACTGCGGGCACA ATGTAGATCTGTCCAAGGCCATAAATTTAAATGGAGTAAACTTCAATAATGTAGACGCCAGTTCACTTGGCG CGGCACACGTAGGACAAAGTGCTAGCCGAGGCAGAGGACTTGGTGAGAACCCAGATGACGAGGAAGGAGA TGCTAAAAAAAAAAAGGATGGAAAGAAAGCAGAACCAAAAAATCCACGTGAAAATAAGCTGAAACAACCA GGAGACAGAGCAGATGGACAGCCAGCAGGAGACAGAGCAGATGGACAGCCAGCAGGTGATAGAGCAGATG GACAACCAGCAGGAGATAGAGCAGCTGGACAACCAGCAGGAGATAGAGCAGATGGACAGCCAGCAGGAGA CAGAGCAGATGGACAGCCAGCAGGAGACAGAGCAGATGGACAACCAGCAGGAGACAGAGCAGATGGACAA CCAGCAGGTGATAGAGCAGCTGGACAACCAGCAGGTGATAGAGCAGCTGGACAACCAGCAGGAGATAGAG CAGATGGACAGCCAGCAGGAGATAGAGCAGCTGGACAGCCAGCAGGAGATAGAGCAGATGGACAGCCAGC AGGAGATAGAGCAGCTGGACAGCCAGCAGGAGATAGAGCAGATGGACAGCCAGCAGGAGATAGAGCAGCT GGACAGCCAGCAGGAGATAGAGCAGCTGGACAGCCAGCAGGAGATAGAGCAGCTGGACAGCCAGCAGGAG ATAGAGCAGCTGGACAGCCAGCAGGAAATGGTGCAGGTGGACAGGCAGCAGGAGGAAACGCAGGAGGAGG ACAGGGACAAAATAATGAAGGTGCGAATGCCCCAAATGAAAAGTCTGTGAAAGAATACCTAGATAAAGTTA GAGCTACCGTTGGCACCGAATGGACTCCATGCAGTGTAACCTGTGGAGTGGGTGTAAGAGTCAGAAGAAGA GTTAATGCAGCTAACAAAAAACCAGAGGATCTTACTTTGAATGACCTTGAGACTGATGTTTGTACAATGGAT AAGTGTGCTGGCATATTTAACGTTGTGAGTAATTCATTAGGGCTAGTCATATTGTTAGTCCTAGCATTATTCA ATTAA

\section{P. vivax (VK247) - EU401928}

ATGAAGAACTTCATTCTCTTGGCTGTTTCTTCCATCCTGTTGGTGGACTTGTTCCCCACGCACTGCGGGCACA ATGTAGATCTGTCCAAGGCCATAAATTTAAATGGAGTAGGCTTCAATAATGTAGACGCCAGTTCACTTGGCG CGGCACACGTAGGACAAAGTGCTAGCCGAGGCAGAGGACTTGGTGAGAACCCAGATGACGAGGAAGGAGA TGCTAAAAAAAAAAAGGATGGAAAGAAAGCAGAACCAAAAAATCCACGTGAAAATAAGCTGAAACAACCA GAAGATGGGGCAGGCAATCAACCAGGAGCAAATGGAGCAGGCAATCAACCAGGAGCAAATGGGGCAGGCA ATCAACCAGGAGCAAATGGGGCAGGCAATCAACCAGGAGCAAATGGGGCTGGCAATCAACCAGGAGCAAA TGGGGCTGGCAATCAACCAGGAGCAAATGGGGCTGGCAATCAACCAGGAGCAAATGGGGCTGGCAATCAAC CAGGAGCAAATGGAGCAGATGATCAACCAGGAGCAAATGGGGCAGGCAATCAACCAGGAGCAAATGGGGC TGGCAATCAACCAGGAGCAAATGGGGCAGGTAATCAACCAGGAGCAAATGGAGCAGGTGATCAACCAGGA GCAAATGGGGCTGGCAATCAACCAGGAGCAAATGGAGCAGGTGATCAACCAGGAGCAAATGGGGCCGGCA ATCAACCAGGAGCAAATGGGGCCGGCAATCAACCAGGAGCAAATGGGGCACGTAATCAACCAGGAGCAAAT GGGGCAGGTGGACAGGCAGCAGGAAATGGTGCAGGTGGACAGGCAGCAGGAGGAAATGCGGCAAACAAGA AGGCAGAAGACGCAGGAGGAAACGCAGGAGGAAACGCAGGAGGACAGGGACAAAATAATGAAGGTGCGA ATGCCCCAAATGAAAAGTCTGTGAAAGAATACCTAGATAAAGTTAGAGCTACCGTTGGCACCGAATGGACTC CATGCAGTGTAACCTGTGGAGTGGGTGTAAGAGTCAGAAGAAGAGTTAATGCAGCTAACAAAAAACCAGAG GATCTTACTTTGAATGACCTTGAGACTGATGTTTGTACAATGGATAAGTGTGCTGGCATATTTAACGTTGTGA GTAATTCATTAGGGCTAGTCATATTGTTAGTCCTAGCATTATTCAAT 


\section{P. vivax (P. vivax-like) - M11031}

ATGAAGAACTTCATTCTCTTGGCCGTTTCTTCCATCCTGTTGGTGGACTTGTTCCCCACACACTGCGGGCATA ATGTAGATCTCTCCAGGGCCATAAATTTAAATGGAGTAAGCTTCAATAATGTAGACGCCAGTTCACTTGGCG CACGACAGGTAAGACAAAGTGCTAGCCGAGGCAGAGGACTTGGTGAGAACCCAAAAGACGATGAAAAAGC TGATAAACCAAAAAAAAAGGACGAAAAAAAAGTAGAACCAAAAAAGCCACATGAAAATAAGCTGAAACAA CCAGTCCCAGGAGCAAATCAGGAAGGCGGAGCAGCAGCCCCAGGAGCAAATCAGGAAGGTGGAGCAGCAG CCCCAGGTGCAAATCAGGAAGATGGAGCAGCAGCCCCAGGAGCAAACCAGGAAGGTGGAGCAGCAGCCCC AGGAGCAAATCAGGAAGGTGGAGCAGCAGCCCCAGGAGCAAATCAGGAAGGCGGAGCAGCAGCCCCAGGA GCAAATCAGGAAGGTGGAGCAGCAGCCCCAGGTGCAAACCAGGAAGGTGGAGCAGCAGCCCCAGGAGCAA ACCAGGAAGGCGGAGCAGCAGCCCCAGGAGCAAATCAGGAAGGCGGAGCAGCAGCCCCAGGAGCAAATCA GGAAGGTGGAGCAGCAGCCCCAGGAGCAAACCAGGAAGGTGGAGCAGCAGCACCAGGAGCAAACCAGGAA GGTGGAGCAGCAGCACCAGGAGCAAACCAGGGAGGTGGAGCAGCAGCACCAGGAGCAAACCAGGGAGGTG GAGCAGCAGCACCAGGAGCAAACCAGGGAGGTGGAGCAGCAGCACCAGGAGCAAACCAGGAAGGTGGAGC AGCAGCACCAGGAGCAAACCAGGGAGGTGCAAAGCCAGCAGGAGGACAGGGACAAAATAATGAAGGTGCG AATAAGCCAGATGAAAAGCATGTGAAAGAATACCTAGAGAAAATTAGATCTACCGTTGGCACCGAATGGAC TCCATGCAGTGTAACCTGTGGAAAGGGTGTAAGAGTTAGAAGAAAACTTAGTGCAGGTGACAAAAAACCAG ATAAGCTTACTCTGAATGACCTTGAGGCAGAAGTTTGTACAATGGATAAGTGCTCTGGCATATTTAACGTTGT GAGTAATTCATTAGGGCTAGTCATATTGTTAGTCCTAGCATTATTCAATTAA

\subsection{Oligonucleotídeos PFCSP1 e PFCSP2.}

\section{P. falciparum - K02194}

ATGATGAGAAAATTAGCTATTTTATCTGTTTCTTCCTTTTTATTTGTTGAGGCCTTATTCCAGGAATACCAGTG CTATGGAAGTTCGTCAAACACAAGGGTTCTAAATGAATTAAATTATGATAATGCAGGCACTAATTTATATAA TGAATTAGAAATGAATTATTATGGGAAACAGGAAAATTGGTATAGTCTTAAAAAAAATAGTAGATCACTTGG AGAAAATGATGATGGAAATAATAATAATGGAGATAATGGTCGTGAAGGTAAAGATGAAGATAAAAGAGATG GAAATAACGAAGACAACGAGAAATTAAGGAAACCAAAACATAAAAAATTAAAGCAACCAGGGGATGGTAA TCCTGATCCAAATGCAAACCCAAATGTAGATCCCAATGCCAACCCAAATGTAGATCCAAATGCAAACCCAAA TGTAGATCCAAATGCAAACCCAAATGCAAACCCAAATGCAAACCCAAATGCAAACCCAAATGCAAACCCAA ATGCAAACCCAAATGCAAACCCAAATGCAAACCCAAATGCAAACCCCAATGCAAATCCTAATGCAAATCCT AATGCAAACCCAAATGCAAATCCTAATGCAAACCCAAATGCAAACCCAAACGTAGATCCTAATGCAAATCC AAATGCAAACCCAAATGCAAACCCAAACGCAAACCCCAATGCAAATCCTAATGCAAACCCCAATGCAAATC CTAATGCAAATCCTAATGCCAATCCAAATGCAAATCCAAATGCAAACCCAAACGCAAACCCCAATGCAAATC CTAATGCCAATCCAAATGCAAATCCAAATGCAAACCCAAATGCAAACCCAAATGCAAACCCCAATGCAAAT CCTAATAAAAACAATCAAGGTAATGGACAAGGTCACAATATGCCAAATGACCCAAACCGAAATGTAGATGA AAATGCTAATGCCAACAATGCTGTAAAAAATAATAATAACGAAGAACCAAGTGATAAGCACATAGAACAAT ATTTAAAGAAAATAAAAAATTCTATTTCAACTGAATGGTCCCCATGTAGTGTAACTTGTGGAAATGGTATTCA AGTTAGAATAAAGCCTGGCTCTGCTAATAAACCTAAAGACGAATTAGATTATGAAAATGATATTGAAAAAAA AATTTGTAAAATGGAAAAATGTTCCAGTGTGTTTAATGTCGTAAATAGTTCAATAGGATTAATAATGGTATTA TCCTTCTTGTTCCTTAAT 


\title{
1.3. Oligonucleotídeos PMCSP1 e PMCSP2.
}

\author{
P. malariae - J03992
}

ATATAGACTTGCTCCAACATGAAGAAGTTATCTGTCTTAGCAATATCCTCTTTTTTAATTGTTGATTTCCTCTT CCCTGGATATCATCACAACTCAAATTCCACCAAGTCAAGAAATTTAAGTGAGTTGTGTTACAATAATGTGGA CACTAAATTATTTAATGAGTTAGAAGTCAGATATAGCACGAATCAAGATCATTTCTATAACTATAATAAGAC AATCAGATTACTTAATGAAAATAACAATGAAAAAGATGGAAATGTGACCAATGAAAGAAAAAAAAAACCCA CAAAAGCTGTTGAAAATAAATTGAAACAACCCCCCGGAGATGATGATGGCGCAGGAAATGATGCAGGAAAT GATGCAGGAAATGATGCAGGAAATGCAGCAGGAAATGCAGCAGGAAATGCAGCAGGAAATGCAGCAGGTA ACGCAGCAGGTAACGCAGCAGGAAATGCAGCAGGAAATGCAGCAGGTAACGCAGCAGGAAATGCAGCAGG AAATGATGCAGGAAATGCAGCAGGTAACGCAGCAGGAAATGCAGCAGGAAATGCAGCAGGAAATGCAGCA GGAAATGATGCAGGAAATGCAGCAGGAAATGCAGCAGGAAATGCAGCAGGTAACGCAGCAGGAAATGCAG CAGGAAATGCAGCAGGTAACGCAGCAGGTAACGCAGCAGGAAATGCAGCAGGAAATGCAGCAGGAAATGA TGCAGGAAATGCAGCAGGTAACGCAGCAGGAAATGCAGCAGGAAATGCAGCAGGTAACGCAGCAGGTAAC GCAGCAGGAAATGCAGCAGGAAATGCAGCAGGTAACGCAGCAGGAAATGCAGCAGGAAATGCAGCAGGTA ACGCAGCAGGTAACGCAGCAGGAAATGCAGCAGGAAATGCAGCAGGTAACGCAGCAGGAAATGCAGCAGG AAATGCAGCAGGTAACGCAGCAGGAAATGCAGCAGGAAATGAAAAAGCGAAAAATAAGGATAATAAAGTG GATGCAAATACGAATAAAAAGGACAACCAGGAAGAAAATAATGATTCGTCTAATGGTCCATCTGAAGAACA TATAAAGAATTATTTAGAAAGTATTCGTAATAGTATTACGGAGGAATGGTCACCATGTAGTGTAACTTGTGG AAGTGGTATAAGGGCTAGAAGAAAGGTTGGTGCAAAAAATAAGAAACCTGCAGAATTAGTTTTAAGTGACC TTGAAACTGAAATTTGTTCACTAGATAAATGCTCCAGTATATTTAATGTCGTAAGTAATTCGTTAGGAATAGT ATTAGTTTTAGTCTTAATACTCTTTCACTAA 


\section{ANEXO B}

\section{Alinhamento das sequências do gene da CSP}

Apenas as regiões não repetitivas foram analisadas. As posições dos nucleotídeos estão determinadas considerando as sequências com os seguintes números de acesso: M11926, para a variante VK210; EU401928 para a variante VK247; U09738 para a variante $P$. vivax-like; J03992 para o $P$. malariae; K02194 para o P. falciparum. Estão registradas as posições onde foram encontradas variações nucleotídicas quando comparadas com as sequências citadas anteriormente.

\begin{tabular}{|llllllllll|}
\hline Posição do & & $\mathbf{1}$ & $\mathbf{1}$ & $\mathbf{1}$ & $\mathbf{1}$ & $\mathbf{1}$ & $\mathbf{1}$ & $\mathbf{1}$ & $\mathbf{1}$ \\
nucleotídeo & $\mathbf{7}$ & $\mathbf{0}$ & $\mathbf{0}$ & $\mathbf{1}$ & $\mathbf{1}$ & $\mathbf{1}$ & $\mathbf{1}$ & $\mathbf{1}$ & $\mathbf{2}$ \\
& $\mathbf{2}$ & $\mathbf{4}$ & $\mathbf{4}$ & $\mathbf{0}$ & $\mathbf{7}$ & $\mathbf{9}$ & $\mathbf{3}$ & $\mathbf{4}$ & $\mathbf{2}$ \\
& & & & & & & & & $\mathbf{5}$ \\
\hline J03992 & C & A & C & T & A & G & A & G & T \\
\hline S69014 & T & G & & & & & & A & \\
U09766 & T & G & & & & & & A & \\
AJ001523 & & & & C & & & & & \\
AJ001524 & & & & & & & & A & \\
AJ001525 & & & & & & & & A & \\
AJ001526 & & & & & & & & A & \\
AJ002575 & & & & & & & & A & \\
AJ002576 & T & G & & & & & & A & C \\
AJ002577 & & & A & & & & & A & \\
AJ002578 & & & & & & & & A & \\
AJ002579 & & & & & & & G & A & \\
AJ002580 & & & & & & & & A & \\
AJ002581 & & & & & & & & A & \\
AJ002582 & & & & & & A & & A & \\
AJ002583 & & & & & G & & & A & \\
\hline
\end{tabular}

Quadro 1 - Variações na sequência de nucleotídeos do gene da CSP de P. malariae encontradas a partir de 16 isolados, depositadas no GenBank. A posição dos nucleotídeos é baseada no isolado contendo o código de acesso J03992, no sentido 5' - 3’. 


\begin{tabular}{|c|c|c|c|c|c|c|c|c|c|c|c|c|c|c|c|c|c|c|}
\hline $\begin{array}{l}\text { Posição do } \\
\text { nucleotídeo }\end{array}$ & $\begin{array}{l}9 \\
5\end{array}$ & $\begin{array}{l}1 \\
1 \\
0\end{array}$ & $\begin{array}{l}1 \\
5 \\
0\end{array}$ & $\begin{array}{l}2 \\
2 \\
8\end{array}$ & $\begin{array}{l}\mathbf{2} \\
\mathbf{3} \\
\mathbf{0}\end{array}$ & $\begin{array}{l}2 \\
3 \\
1\end{array}$ & $\begin{array}{l}2 \\
3 \\
2\end{array}$ & $\begin{array}{l}\mathbf{2} \\
\mathbf{3} \\
\mathbf{3}\end{array}$ & $\begin{array}{l}2 \\
3 \\
9\end{array}$ & $\begin{array}{l}2 \\
4 \\
0\end{array}$ & $\begin{array}{l}2 \\
4 \\
1\end{array}$ & $\begin{array}{l}2 \\
4 \\
2\end{array}$ & $\begin{array}{l}2 \\
4 \\
3\end{array}$ & $\begin{array}{l}2 \\
4 \\
6\end{array}$ & $\begin{array}{l}2 \\
4 \\
7\end{array}$ & $\begin{array}{l}2 \\
4 \\
8\end{array}$ & $\begin{array}{l}2 \\
4 \\
9\end{array}$ & $\begin{array}{l}2 \\
5 \\
2\end{array}$ \\
\hline M11926 & $\mathbf{T}$ & $\mathbf{T}$ & $\overline{\mathbf{A}}$ & $\overline{\mathbf{A}}$ & $\bar{A}$ & $\mathbf{G}$ & $\mathbf{G}$ & $\bar{A}$ & $\overline{\mathbf{A}}$ & $\mathbf{G}$ & $\bar{A}$ & $\mathbf{A}$ & $\bar{A}$ & $\bar{A}$ & $\mathbf{G}$ & $\bar{A}$ & $\bar{A}$ & $\overline{\mathbf{A}}$ \\
\hline AF164603 & $\mathrm{C}$ & & & & & & & & & & & & & & & & & \\
\hline AF164604 & & & & & & & & & & & & & & & & & & $\mathrm{C}$ \\
\hline AF166407 & & & $\mathrm{T}$ & & & & & & & & & & & & & & & \\
\hline AF166408 & & & & & & & & & & & & & & & & & & $\mathrm{C}$ \\
\hline AF316580 & & & & & & A & A & & & & & & & & & & & \\
\hline AF316581 & & & & & & A & & & & & & & & & & & & \\
\hline AF316582 & & & & & & A & & & & & & & & & & & & \\
\hline AF436890 & & & & & & & & & & & & & & & & & & $\mathrm{C}$ \\
\hline AF436891 & & & & & & A & & G & & & & & & & & & & \\
\hline AJ278612 & & $\mathrm{C}$ & & & & & & & & & & & & & & & & \\
\hline DQ859750 & & & & & & & & & & & & & & & & & & \\
\hline EU031827 & & & & & & & & & & & & & & & & & & \\
\hline EU031828 & & & & & & & & & & & & & & & & & & \\
\hline EU031830 & & & & & & & & & & & & & & & & & & \\
\hline EU031832 & & & & & & & & & & & & & & & & & & \\
\hline EU031835 & & & & & & & & & & & & & & & & & & \\
\hline EU031836 & & & & & & & & & & & & & & & & & & \\
\hline EU401924 & & & & G & & & & & & & & & & & & & & \\
\hline EU401931 & & & & G & & & & & & & & & & & & & & \\
\hline FJ491070 & & & & & & & & & & & & & & & & & & \\
\hline FJ491071 & & & & & & & & & & & & & & & & & & \\
\hline FJ491072 & & & & & G & & & G & G & & & & & & & & & $\mathrm{C}$ \\
\hline FJ491075 & & & & & . & & & & & & & & & & & & & $\mathrm{C}$ \\
\hline FJ491077 & & & & & G & & & $\mathrm{G}$ & G & & & & & & & & & $\mathrm{C}$ \\
\hline FJ491079 & & & & & & & & & & & & & & & & & & \\
\hline FJ491080 & & & & & & & & & & & & & & & & & $\mathrm{C}$ & \\
\hline FJ491082 & & & & & & & & & & & & & & & & & & \\
\hline FJ491084 & & & & & & & & & & & & & & & & & & \\
\hline FJ491085 & & & & & & & & & & & & & & & & & & \\
\hline FJ491090 & & & & & & & & & & & & & & & & & & \\
\hline FJ491091 & & & & & & & & & & & & & & & & & & \\
\hline FJ491094 & & & & & & & & & & & & & & & & & & $\mathrm{C}$ \\
\hline FJ491095 & & & & & & & & & & & & & & & A & & & $\mathrm{C}$ \\
\hline FJ491097 & & & & & & & & & & & & & & & & & & \\
\hline FJ491099 & & & & & & & & & & & & & & & & & & \\
\hline FJ491101 & & & & & & & & & & & & & & & & & & \\
\hline FJ491106 & & & & & & & & & & & & & & & & G & & $\mathrm{C}$ \\
\hline FJ491110 & & & & & & & & & & & & & & & & & & $\mathrm{C}$ \\
\hline FJ491111 & & & & & & & & & & & & & & & & & & $\mathrm{C}$ \\
\hline FJ491113 & & & & & G & & & & & & & & & & & & & \\
\hline FJ491114 & & & & & G & & & & & & & & & & & & & \\
\hline FJ491115 & & & & & G & & & & & & & & & & & & & \\
\hline FJ491116 & & & & & G & & & & & & & & & & & & & \\
\hline FJ491117 & & & & & G & & & & & & & & G & G & & & & \\
\hline FJ491118 & & & & & G & & & & & & & & & & & & & \\
\hline FJ491119 & & & & & G & & & & & & & & & & & & & \\
\hline FJ491120 & & & & & G & & & & & & & & & & & & & \\
\hline FJ491121 & & & & & G & & & & & & & & & & & & & \\
\hline FJ491122 & & & & & G & & & & & & & $\mathrm{C}$ & & & & G & & \\
\hline FJ491123 & & & & & G & & & & & & & & & & & & & \\
\hline FJ491124 & & & & & G & & & & & & & & & & & & & \\
\hline FJ491125 & & & & & G & & & & & & & & & & & & & \\
\hline FJ491126 & & & & & & & & & & & & & & & & & & \\
\hline FJ491127 & & & & & G & & & & & & & & & & & & & \\
\hline FJ491128 & & & & & G & & & & & & & & & & & & & \\
\hline FJ491129 & & & & & & & & & & & & & & G & & & & \\
\hline
\end{tabular}

Quadro 2 - continua. Variações na sequência de nucleotídeos da região $5^{\prime}$ do gene da CSP de $P$. vivax VK210 encontradas a partir de 315 isolados, depositadas no GenBank. A posição dos nucleotídeos é baseada no isolado contendo o código de acesso M11926, no sentido 5' - 3'. 


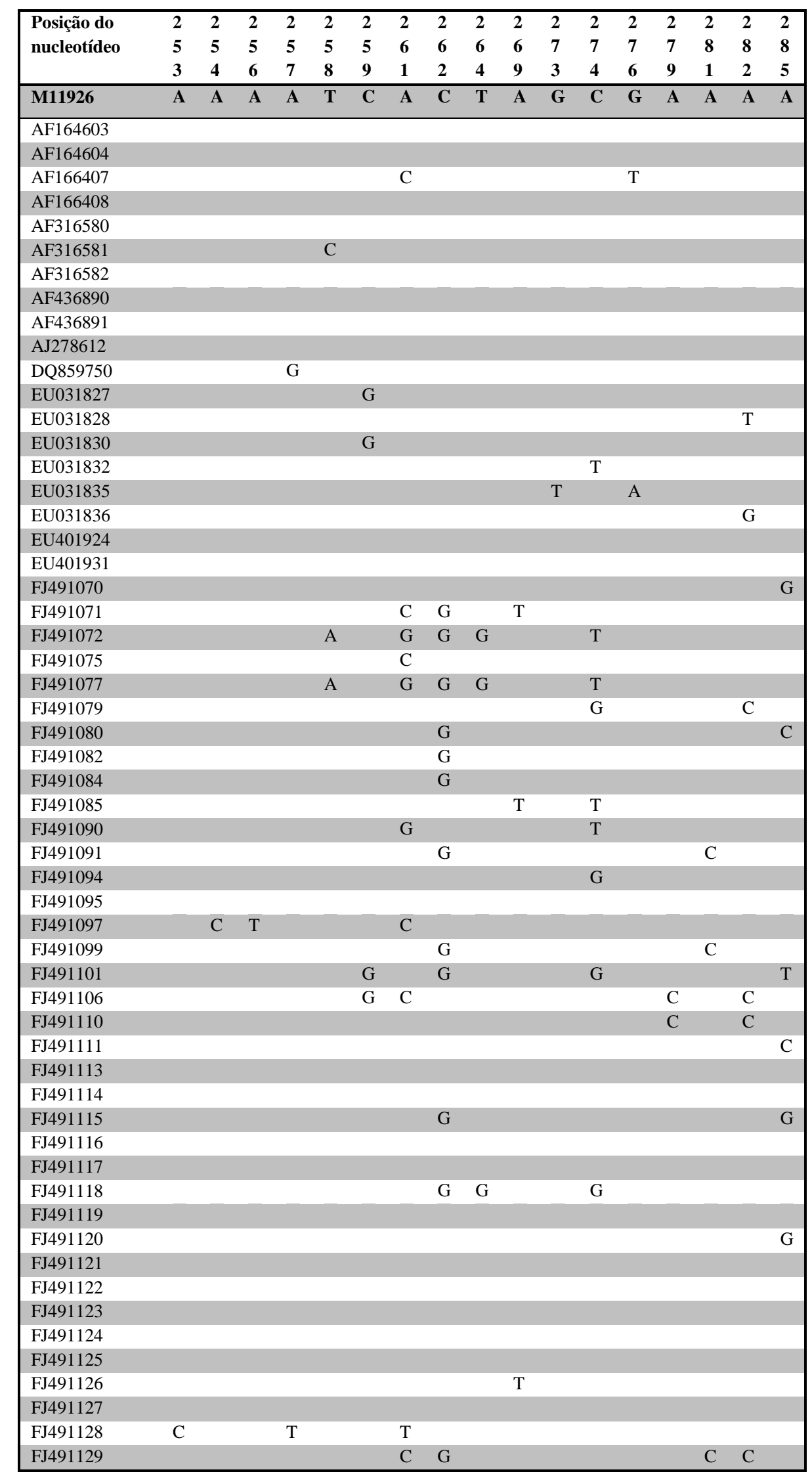

Quadro 2 - conclusão. Variações na sequência de nucleotídeos da região $5^{\prime}$ do gene da CSP de $P$. vivax VK210 encontradas a partir de 315 isolados, depositadas no GenBank. A posição dos nucleotídeos é baseada no isolado contendo o código de acesso M11926, no sentido 5' - 3'. 


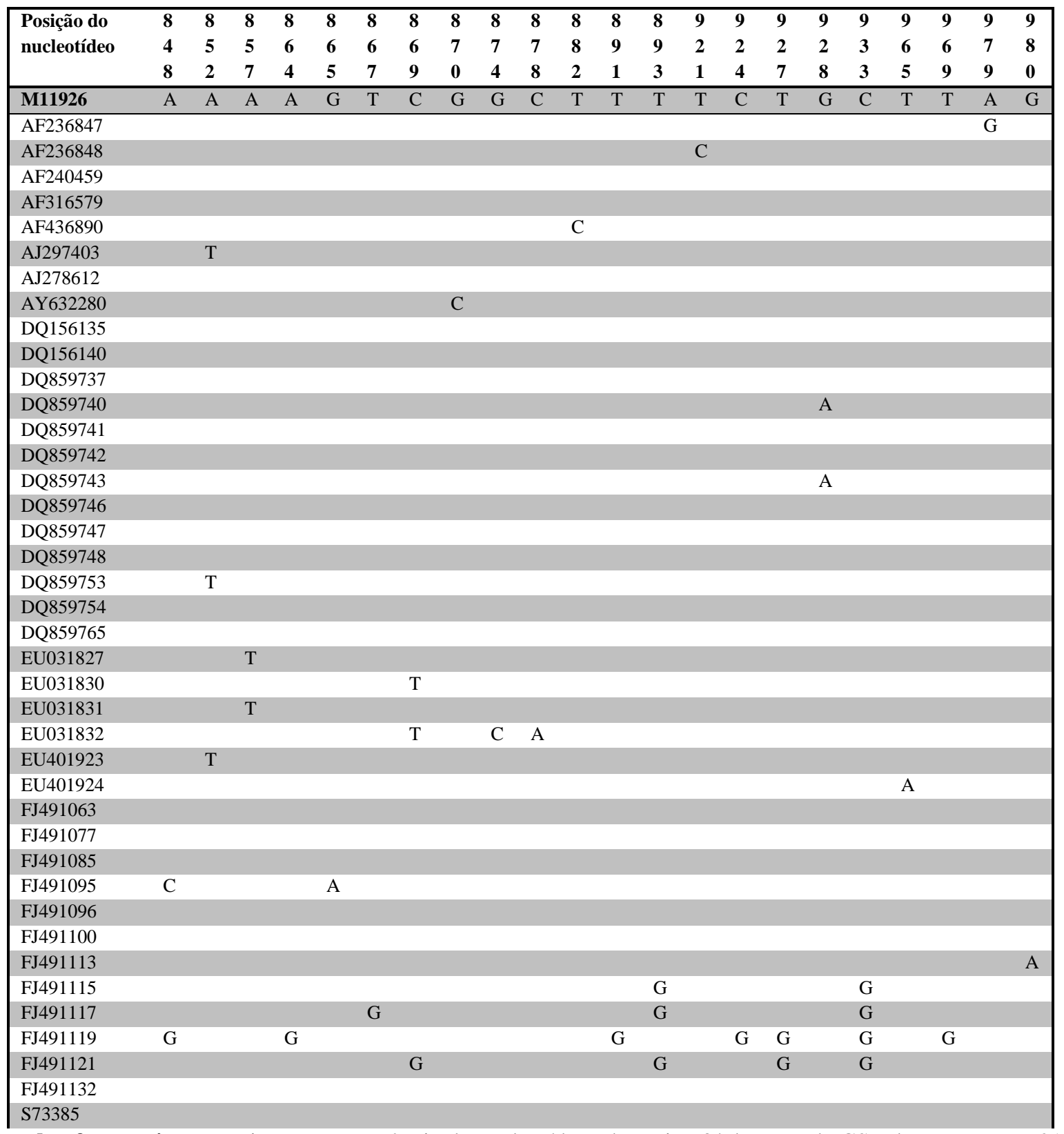

Quadro 3 - continua. Variações na sequência de nucleotídeos da região 3’ do gene da CSP de P. vivax VK210 encontradas a partir de 315 isolados, depositadas no GenBank. A posição dos nucleotídeos é baseada no isolado contendo o código de acesso M11926, no sentido 5' - 3’. 


\begin{tabular}{|c|c|c|c|c|c|c|c|c|c|c|c|c|c|c|c|c|c|c|c|c|c|c|c|}
\hline & & & & 1 & 1 & 1 & 1 & 1 & 1 & 1 & 1 & 1 & 1 & 1 & 1 & 1 & 1 & 1 & 1 & 1 & 1 & 1 & 1 \\
\hline Posição do & 9 & 9 & 9 & $\mathbf{0}$ & $\mathbf{0}$ & $\mathbf{0}$ & $\mathbf{0}$ & $\mathbf{0}$ & $\mathbf{0}$ & $\mathbf{0}$ & $\mathbf{0}$ & $\mathbf{0}$ & 0 & $\mathbf{0}$ & $\mathbf{0}$ & $\mathbf{0}$ & $\mathbf{0}$ & $\mathbf{0}$ & $\mathbf{0}$ & $\mathbf{0}$ & 1 & 1 & 1 \\
\hline nucleotídeo & 8 & 9 & 9 & $\mathbf{0}$ & 0 & 1 & 2 & 2 & 2 & 3 & 3 & 4 & 4 & 4 & 6 & 6 & 7 & 7 & 8 & 9 & $\mathbf{0}$ & 1 & 1 \\
\hline & 5 & 1 & 3 & 1 & 8 & 9 & 4 & 5 & 6 & $\mathbf{1}$ & 5 & 0 & 1 & 3 & 3 & 7 & 1 & 7 & 3 & 9 & 5 & 7 & 8 \\
\hline M11926 & $\mathrm{A}$ & $\mathrm{A}$ & $\mathrm{T}$ & $\mathrm{A}$ & $\mathrm{C}$ & $\mathrm{T}$ & $\mathrm{T}$ & $\mathrm{T}$ & $\mathrm{G}$ & $\mathrm{A}$ & $\mathrm{A}$ & $\mathrm{C}$ & $\mathrm{T}$ & $\mathrm{A}$ & $\mathrm{T}$ & $\mathrm{C}$ & $\mathrm{C}$ & $\mathrm{T}$ & $\mathrm{T}$ & $\mathrm{G}$ & $\mathrm{T}$ & $\mathrm{G}$ & $\mathrm{T}$ \\
\hline AF236847 & & & & & & & & & & & & & & & & & & & & & & & \\
\hline AF236848 & & & & & & & & & & & & & & G & & & & & & & & & \\
\hline AF240459 & & G & & & & & & & & & & & & & & & & & & & & & \\
\hline AF316579 & & & & & & & $\mathrm{C}$ & & & & & & & & & & & & & & & & \\
\hline AF436890 & & & & & & & & & & & & & & & & & & & & & & & \\
\hline AJ 297403 & & & & & & & & & & & & & & & & & & & & & & & \\
\hline AJ278612 & & & & & & & & & A & & & & & & & & & & & & & & \\
\hline AY632280 & & & & & & & & & & & & & & & & & & & & & & & \\
\hline DQ156135 & & & & & & & & & & & & & & & & & & & & & & & \\
\hline DQ156140 & & & & & & & & & & & & & & & & & & & & & & & \\
\hline DQ859737 & & & & & & & & & & & & & & & & & $\mathrm{T}$ & & & & & & \\
\hline DQ859740 & & & & & $\mathrm{T}$ & & & & & & & & & & & & & & & & & & \\
\hline DQ859741 & & & & & & & & & & $\mathrm{C}$ & & & & & & & & & & & & & \\
\hline DQ859742 & & & & & & & & & & & & & & & & & $\mathrm{T}$ & & & & & & \\
\hline DQ859743 & & & & & & & & & & & & & & & & & & & & & & & \\
\hline DQ859746 & & & & & & & & & & & & & & & $\mathrm{C}$ & & & & & & & & \\
\hline DQ859747 & & & & & & & & & & $\mathrm{C}$ & & & & & & & & & & & & & \\
\hline DQ859748 & & & & & & & & & & $\mathrm{C}$ & & & & & & & & & & & & & \\
\hline DQ859753 & & & & & & & & & & & & & & & & & & & & & & & \\
\hline DQ859754 & & & & & & A & & & & & & & & & & & & & & & & & \\
\hline DQ859765 & G & & & & & & & & & & & & & & & & & & & & & & \\
\hline EU031827 & & & & & & & & & & & & & & & & & & & & & & & \\
\hline EU031830 & & & & & & & & & & & & & & & & & & & & & & & \\
\hline EU031831 & & & & & & & & & & & & & & & & & & & & & & & \\
\hline EU031832 & & & & & & & & & & & & & & & & & & & & & & & \\
\hline EU401923 & & & & & & & & & & & & & & & & & & & & & & & \\
\hline EU401924 & & & & & & & & & & & & & & & & & & & & & & & \\
\hline FJ491063 & & & & G & & & & & & & & & & & & & & & & & & & \\
\hline FJ491077 & & & & & & & & & & & & & G & & & & & & & & & & \\
\hline FJ491085 & & & & & & & & & & & & & & & & & & & $\mathrm{C}$ & & & & \\
\hline FJ491095 & & & & & & & & & & & & G & & & & & & & & & & & \\
\hline FJ491096 & & & & & & & & & & & & G & & & & & & & & & & & \\
\hline FJ491100 & & & & & & & & & & & & A & & & & & & & & & & & \\
\hline FJ491113 & & & & & & & & & & & & & & & & & & & & & & & \\
\hline FJ491115 & & & & & & & G & & & & G & & & & & G & & & & & & & \\
\hline FJ491117 & & & & & & & & & & & & & & & & & & & & & & & \\
\hline FJ491119 & & & G & & & & & G & & & G & & & & & G & & & & & & & \\
\hline FJ491121 & & & & & & & & & & & G & & & & & & & & & & & & \\
\hline FJ491132 & & & & & & & & & & & & & & & & & & A & & & & & \\
\hline S73385 & & & & & & & & & & & & & & & & & & & & $\mathrm{C}$ & G & $\mathrm{T}$ & G \\
\hline
\end{tabular}

Quadro 3 - conclusão. Variações na sequência de nucleotídeos da região 3' do gene da CSP de P. vivax VK210 encontradas a partir de 315 isolados, depositadas no GenBank. A posição dos nucleotídeos é baseada no isolado contendo o código de acesso M11926, no sentido 5' - 3'.

Os isolados com os seguintes códigos de acesso no GenBank apresentam uma troca de adenina por guanina na posição 1005: DQ156135, DQ156140, FJ491063, FJ491064, FJ491068, FJ491070, FJ491072, FJ491073, FJ491075, FJ491076, FJ491077, FJ491078, FJ491080, FJ491081, FJ491083, FJ491084, FJ491085, FJ491088, FJ491089, FJ491090, FJ491091, FJ491093, FJ491095, FJ491096, FJ491097, FJ491100, FJ491101, FJ491102, FJ491103, FJ491105, FJ491106, FJ491109, FJ491110, FJ491112, FJ491114, FJ491115, FJ491116, FJ491120, FJ491123, FJ491125, FJ491127, FJ491129, FJ491130, FJ491131, FJ491132, FJ491133, FJ491134, FJ491135, FJ491136, FJ491137, FJ491138, FJ491139, FJ491140, FJ491141. 
Os isolados com os seguintes códigos de acesso no GenBank apresentam uma troca de citosina por adenina na posição 1033: DQ156135, FJ491063, FJ491064, FJ491065, FJ491068, FJ491069, FJ491070, FJ491071, FJ491072, FJ491073, FJ491074, FJ491075, FJ491076, FJ491077, FJ491078, FJ491080, FJ491081, FJ491082, FJ491083, FJ491084, FJ491085, FJ491086, FJ491087, FJ491088, FJ491089, FJ491090, FJ491091, FJ491092, FJ491093, FJ491094, FJ491095, FJ491096, FJ491097, FJ491099, FJ491100, FJ491101, FJ491102, FJ491103, FJ491104, FJ491105, FJ491106, FJ491107, FJ491108, FJ491109, FJ491110, FJ491111, FJ491112, FJ491114, FJ491115, FJ491116, FJ491122, FJ491123, FJ491124, FJ491125, FJ491127, FJ491129, FJ491130, FJ491131, FJ491132, FJ491133, FJ491134, FJ491135, FJ491136, FJ491137, FJ491138, FJ491139, FJ491140, FJ491141.

\begin{tabular}{|c|c|c|c|c|c|c|c|c|c|c|c|c|c|c|c|}
\hline & & & & & & & & & & 1 & 1 & 1 & 1 & 1 & 1 \\
\hline Posição do & 2 & 2 & 2 & 3 & 3 & 9 & 9 & 9 & 9 & $\mathbf{0}$ & $\mathbf{0}$ & $\mathbf{0}$ & $\mathbf{0}$ & $\mathbf{0}$ & $\mathbf{0}$ \\
\hline \multirow{2}{*}{ Nucleotídeo } & 8 & 9 & 9 & 0 & 0 & 0 & 2 & 3 & 4 & 2 & 4 & 5 & 7 & 8 & 8 \\
\hline & 7 & 4 & 7 & 0 & 1 & 1 & 2 & 6 & 1 & 3 & 2 & 0 & 8 & 1 & 6 \\
\hline EU401928 & $\mathbf{A}$ & $\mathbf{G}$ & $\mathbf{A}$ & $\mathbf{C}$ & $\mathbf{A}$ & $\mathbf{A}$ & $\mathbf{C}$ & $\mathbf{T}$ & $\mathbf{A}$ & $\mathrm{C}$ & $\mathbf{G}$ & $\mathbf{A}$ & $\mathbf{C}$ & $\mathbf{G}$ & $T$ \\
\hline AF316584 & & & & & & & & $\mathrm{A}$ & & & & & & & \\
\hline AY443708 & & A & & $\mathrm{T}$ & $\mathrm{G}$ & & & & & & & & & & \\
\hline AY443713 & & & & $\mathrm{T}$ & $\mathrm{G}$ & & & & & & & & & & \\
\hline AY632245 & & & & $\mathrm{T}$ & $\mathrm{G}$ & & & & & & & & & & \\
\hline AY632251 & & & & $\mathrm{T}$ & G & & & & & & & & & & \\
\hline AY632252 & & & & $\mathrm{T}$ & $\mathrm{G}$ & & & & & & & & & & \\
\hline AY632253 & & & & $\mathrm{T}$ & $\mathrm{G}$ & & & & & & & & & & \\
\hline AY632254 & & & & $\mathrm{T}$ & $\mathrm{G}$ & & & & & & & & & & \\
\hline AY632293 & & A & & $\mathrm{T}$ & $\mathrm{G}$ & & & & & & & & & & \\
\hline AY632294 & & A & & $\mathrm{T}$ & $\mathrm{G}$ & & & & & & & & & & \\
\hline AY632295 & & A & & $\mathrm{T}$ & $\mathrm{G}$ & & & & & & & & & & \\
\hline AY632297 & & $\mathrm{A}$ & $\mathrm{T}$ & $\mathrm{T}$ & $\mathrm{G}$ & & & & & & & & & & \\
\hline AY632298 & & A & & $\mathrm{T}$ & G & & & & & & & & & & \\
\hline AY632299 & & A & & $\mathrm{T}$ & $\mathrm{G}$ & & & & & & & & & & \\
\hline AY632316 & & & & $\mathrm{T}$ & $\mathrm{G}$ & & & & & & & & & & \\
\hline AY632324 & & A & & $\mathrm{T}$ & $\mathrm{G}$ & & & & & & & & & & \\
\hline AY632328 & & & & $\mathrm{T}$ & G & & & & & & & & & & \\
\hline AY632330 & & & & $\mathrm{T}$ & G & & & & & & & & & & \\
\hline EU401926 & & & & & & & & & & & & G & A & & \\
\hline EU401927 & & & & & & & & & & & & $\mathrm{G}$ & A & & \\
\hline EU401930 & & & & & & $\mathrm{G}$ & & & & & & & & A & $\mathrm{C}$ \\
\hline M69059 & G & A & & $\mathrm{T}$ & G & & A & & & G & & & & & \\
\hline M69060 & G & A & & $\mathrm{T}$ & G & & & & $\mathrm{T}$ & & & & & & \\
\hline M69061 & G & $\mathrm{A}$ & & $\mathrm{T}$ & $\mathrm{G}$ & & & & $\mathrm{T}$ & & & & & & \\
\hline M69062 & $\mathrm{G}$ & A & & $\mathrm{T}$ & $\mathrm{G}$ & & & & $\mathrm{T}$ & & A & & & & \\
\hline
\end{tabular}

Quadro 4 - Variações na sequência de nucleotídeos do gene da CSP de P. vivax VK247 encontradas a partir de 42 isolados, depositadas no GenBank. A posição dos nucleotídeos é baseada no isolado contendo o código de acesso EU401928, no sentido 5’ - 3’. 


\begin{tabular}{|c|c|c|c|c|c|c|c|c|c|c|c|}
\hline \multirow{3}{*}{$\begin{array}{l}\text { Posição do } \\
\text { Nucleotídeo }\end{array}$} & & 1 & 1 & 2 & 2 & 3 & 3 & 3 & 3 & 3 & 3 \\
\hline & 9 & 3 & 3 & 5 & 8 & 0 & 0 & 1 & 5 & 5 & 6 \\
\hline & 3 & 4 & 5 & 9 & 2 & 0 & 9 & 2 & 3 & 6 & 9 \\
\hline K02194 & $\mathbf{C}$ & $\mathbf{C}$ & $\mathbf{T}$ & $\mathrm{C}$ & $\mathbf{A}$ & $\mathbf{A}$ & $\mathbf{G}$ & $\mathbf{A}$ & $\mathbf{A}$ & $\bar{G}$ & $\mathbf{A}$ \\
\hline AB121018 & & & & & & & & & & & \\
\hline AB121023 & & & & & & & & & & A & \\
\hline AF540441 & & & & & & & & & & & $\mathrm{C}$ \\
\hline AF540456 & & & & & & & A & & & & \\
\hline AF540460 & & & & & & & & $\mathrm{C}$ & & & \\
\hline AF540464 & & & & & & & & & & & \\
\hline AF540466 & & & & & & G & & & & & \\
\hline AF540469 & & & & & & & & & & & \\
\hline AF540470 & & & & & & & & & & & \\
\hline AF540471 & & & & & & & & & & & \\
\hline AF540475 & & & & & & & & & & & \\
\hline AF540482 & & & & & & & & & & & \\
\hline AF540483 & & & & & & & & & G & A & \\
\hline AF540484 & & & & & & & & & G & A & \\
\hline AF540485 & & & & & & & & & G & A & \\
\hline AF540486 & & & & & & & & & G & A & \\
\hline AF540487 & & & & & & & & & G & A & \\
\hline AF540488 & & & & & $\mathrm{G}$ & & & & & & \\
\hline AY878598 & & & & & & & & & & & \\
\hline AY878619 & & & & & & & & & & & \\
\hline AY878621 & $\mathrm{T}$ & & & & & & & & & & \\
\hline AY878623 & & & & & & & & & & & \\
\hline AY878637 & & & & & & & & & & & \\
\hline AY878638 & & & & & & & & & & & \\
\hline DQ521733 & & & & & & & & & $\mathrm{G}$ & A & \\
\hline DQ521735 & & & & & & & & & G & A & \\
\hline DQ521736 & & & & & & & & & G & A & \\
\hline DQ521737 & & & & & & & & & G & A & \\
\hline DQ521742 & & & & & & & & & G & A & \\
\hline DQ521744 & & & & & & & & & G & A & \\
\hline DQ521746 & & & & & & & & & $\mathrm{G}$ & A & \\
\hline DQ521748 & & & & & & & & & $\mathrm{G}$ & A & \\
\hline DQ521750 & & & & & & & & & G & A & \\
\hline DQ521752 & & & & & & & & & G & A & \\
\hline M83149 & & $\mathrm{T}$ & $\mathrm{C}$ & & & & & & & & \\
\hline M83150 & & $\mathrm{T}$ & $\mathrm{C}$ & & & & & & & & \\
\hline M83152 & & $\mathrm{T}$ & $\mathrm{C}$ & & & & & & & & \\
\hline M83155 & & $\mathrm{T}$ & $\mathrm{C}$ & & & & & & & & \\
\hline M83156 & & $\mathrm{T}$ & $\mathrm{C}$ & & & & & & & & \\
\hline M83158 & & $\mathrm{T}$ & $\mathrm{C}$ & & & & & & & & \\
\hline M83161 & & $\mathrm{T}$ & $\mathrm{C}$ & & & & & & & & \\
\hline M83163 & & $\mathrm{T}$ & $\mathrm{C}$ & & & & & & & & \\
\hline M83164 & & $\mathrm{T}$ & $\mathrm{C}$ & & & & & & & & \\
\hline M83165 & & $\mathrm{T}$ & $\mathrm{C}$ & & & & & & & & \\
\hline M83166 & & $\mathrm{T}$ & $\mathrm{C}$ & & & & & & & & \\
\hline M83167 & & $\mathrm{T}$ & $\mathrm{C}$ & & & & & & & & \\
\hline M83168 & & $\mathrm{T}$ & $\mathrm{C}$ & & & & & & & & \\
\hline M83169 & & $\mathrm{T}$ & $\mathrm{C}$ & & & & & & & & \\
\hline M83170 & & $\mathrm{T}$ & $\mathrm{C}$ & & & & & & & & \\
\hline M83172 & & $\mathrm{T}$ & $\mathrm{C}$ & & & & & & & & \\
\hline M83173 & & $\mathrm{T}$ & $\mathrm{C}$ & & & & & & & & \\
\hline M83174 & & $\mathrm{T}$ & $\mathrm{C}$ & & & & & & & & \\
\hline U20969 & & & & G & & & & & & & \\
\hline
\end{tabular}

Quadro 5 - Variações na sequência de nucleotídeos da região 5’ do gene da CSP de P. falciparum encontradas a partir de 357 isolados, depositadas no GenBank. A posição dos 
nucleotídeos é baseada no isolado contendo o código de acesso K02194, no sentido 5' $-3^{\prime}$.

Os isolados com os seguintes códigos de acesso no GenBank apresentam uma troca de timina por citosina na posição 350: AB121018, AB121024, AF540446, AF540447, AF540448, AF540449, AF540450, AF540451, AF540452, AF540453, AF540454, AF540455, AF540456, AF540458, AF540459, AF540460, AF540461, AF540462, AF540463, AF540464, AF540465, AF540466, AF540467, AF540468, AF540469, AF540470, AF540471, AF540473, AF540474, AF540475, AF540477, AF540480, AF540488, AY878598, AY878601, AY878602, AY878603, AY878604, AY878605, AY878606, AY878607, AY878611, AY878612, AY878614, AY878615, AY878616, AY878619, AY878620, AY878622, AY878623, AY878624, AY878625, AY878629, AY878630, AY878631, AY878632, AY878636, AY878637, AY878638, AY878639, AY878640, AY878641, M19752, M22982, M57498, M83886, U20969, X15363. 


\section{ANEXO C}

\section{Condições para a reação do $C S$-PCR}

\begin{tabular}{|ccc|}
\hline Etapa & Temperatura $\left({ }^{\circ} \mathbf{C}\right)$ & Duração \\
\hline Desnaturação inicial & 94 & 10 minutos \\
Desnaturação* & 94 & 01 minuto \\
Anelamento* & 58 & 01 minuto \\
Extensão* & 72 & 01 minuto \\
Extensão final & 72 & 10 minutos \\
\hline
\end{tabular}

Quadro 1 - Programa de amplificação utilizado para o gene $C S$ do $P$. vivax, $P$. falciparum e $P$. malariae.

*O ciclo desnaturação-anelamento-extensão foi repetido 30 vezes.

\begin{tabular}{|cc|}
\hline Reagentes & Concentração final \\
\hline Tampão & $1 \mathrm{X}$ \\
$\mathrm{MgCl}_{2}$ & $1,5 \mathrm{mM}$ \\
$\mathrm{dNTP}$ & $0,2 \mathrm{mM}$ \\
PVCSP1/ PFCSP1/ PMCSP1 & $0,2 \mu \mathrm{M}$ \\
PVCSP2/ PFCSP2/ PMCSP2 & $0,2 \mu \mathrm{M}$ \\
Taq DNA Polimerase (Invitrogen & $0,1 \mathrm{U}$ \\
Life Technologies, Brasil) & \\
Água Milli-Q & q.s.p. $25 \mu \mathrm{L}$ \\
DNA & $3-5 \mu \mathrm{L}$ \\
\hline
\end{tabular}

Quadro 2 - Condições de reação utilizadas para a amplificação do gene $C S$. 


\section{ANEXO D}

\section{Protocolo utilizado para a amplificação do ITS2 de Anopheles, segundo} Kampen (2005)

\begin{tabular}{|ccc|}
\hline Etapa & Temperatura $\left({ }^{\circ} \mathbf{C}\right)$ & Duração \\
\hline Desnaturação inicial & 94 & 10 minutos \\
Desnaturação* $^{*}$ & 94 & 01 minuto \\
Anelamento* $^{*}$ & 50 & 01 minuto \\
Extensão* & 72 & 01 minuto \\
Extensão final & 72 & 10 minutos \\
\hline
\end{tabular}

Quadro 1 - Programa de amplificação utilizado para o gene ITS2 do Anopheles.

*O ciclo desnaturação-anelamento-extensão foi repetido 35 vezes.

\begin{tabular}{|cc|}
\hline Reagentes & Concentração final \\
\hline Tampão & $1 \mathrm{X}$ \\
$\mathrm{MgCl}_{2}$ & $1,0 \mathrm{mM}$ \\
$\mathrm{dNTP}$ & $0,2 \mathrm{mM}$ \\
$\mathrm{UN} 1$ & $0,2 \mu \mathrm{M}$ \\
$\mathrm{UN} 2$ & $0,2 \mu \mathrm{M}$ \\
Taq DNA Polimerase (Invitrogen & $1,25 \mathrm{U}$ \\
Life Technologies, Brasil) & \\
Água Milli-Q & q.s.p. $50 \mu \mathrm{L}$ \\
DNA & $1-3 \mu \mathrm{L}$ \\
\hline
\end{tabular}

Quadro 2 - Condições de reação utilizadas para a amplificação do gene ITS2 do Anopheles 
2. Amplificação da região ITS2 do Anopheles

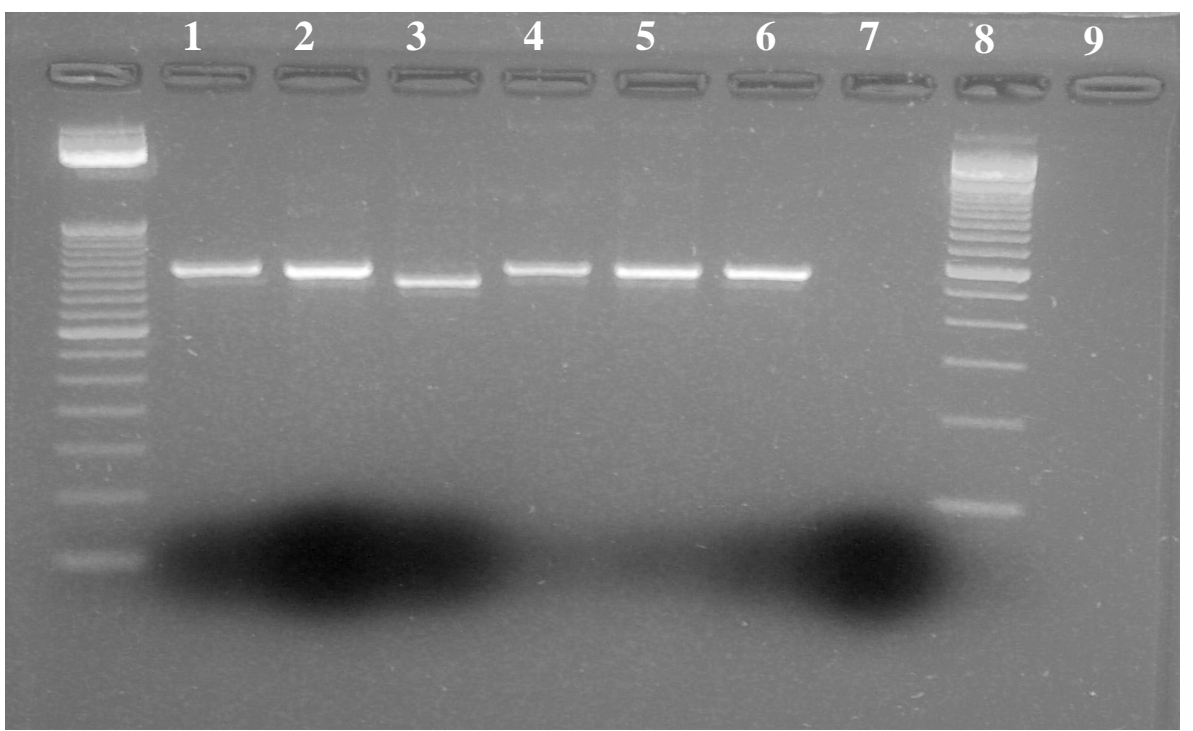

Figura 1 - Amplificação da região ITS2 do Anopheles darlingi, extraídas com o DNAzol (Invitrogen, U.S.A.). Coluna 1: peso molecular de $50 \mathrm{pb}$. Colunas 2-7: Amplificação da região ITS2 das amostras 1-6 de An. darlingi, com aproximadamente 600 pb. Coluna 8: Controle negativo. Coluna 9: peso molecular de $100 \mathrm{pb}$. 


\title{
ANEXO E
}

\section{Parecer do Comitê de Ética}

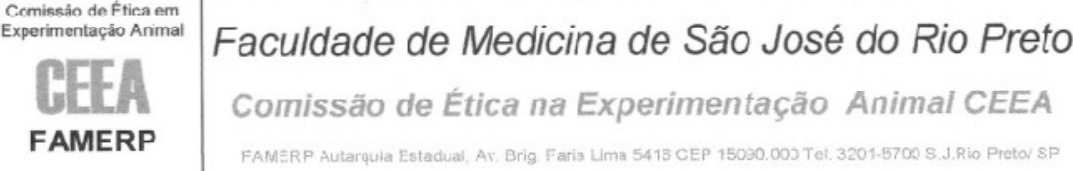

\begin{abstract}
O projeto de pesquisa intitulado "Determinação da infectividade em anofelinos por diagnóstico molecular." (Protocolo FAMERP $n^{\circ} 375008$ ) sob responsabilidade do Prof. Dr. Ricardo Luiz Dantas Machado, por cumprir com os princípios éticos exigidos em experimentação animal, foi aprovado pela CEEAFAMERP.
\end{abstract}

Lembramos ao senhor pesquisador a necessidade de relatório completo ao final do estudo.

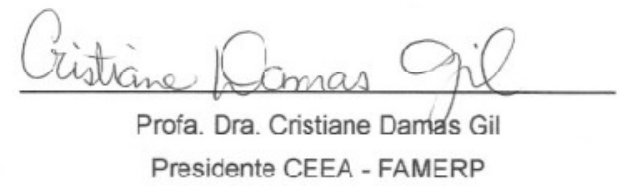


Autorizo a reprodução xerográfica para fins de pesquisa.

São José do Rio Preto, 26 de fevereiro de 2010

Assinatura 